\title{
Concise review of Cladophora spp.: macroalgae of commercial interest
}

\author{
Izabela Michalak ${ }^{1}$ (D) - Beata Messyasz $^{2}$ (D) \\ Received: 10 February 2020 / Revised and accepted: 20 July 2020 / Published online: 3 September 2020 \\ (C) The Author(s) 2020
}

\begin{abstract}
This study includes information about the most common freshwater and marine species from the genus Cladophora such as classification, taxonomy and morphology, ecology, occurrence and distribution, population and community structure, harvesting and culture conditions, chemical composition, and utilization. Habitat requirements and development optima are different for species belonging to the commonly recorded genus Cladophora. The majority Cladophora species are distributed throughout the world, in both the moderate and tropical zones. Of the species noted from Europe, only 15 are characterized for freshwaters, both flowing and standing. In small water bodies, these green algae are very common and occur almost everywhere: in lakes, dam reservoirs, large rivers occur mainly in the coastal littoral zone. A commonly occurring species of macroscopic green algae is Cladophora glomerata. Habitat parameters have shown that the distribution pattern of filamentous green algae taxa is determined by two different gradients: (i) depth - temperature, light availability, oxygen concentration; and (ii) trophy-nitrate and orthophosphate concentration. A fast growth rate of Cladophora is very effective under good light condition and high concentration of nutrients. Species of the genera Cladophora have been determined to be early spring or summer organisms. The biomass of Cladophora can be successfully applied as a raw material for production of value-added products. In this review, Cladophora species are discussed in terms of their chemical composition, as well as potential applications in many areas, for example human and animal health, agriculture (organic fertilizers, biostimulants of plant growth, feed additives), environmental protection (bioindicator of pollution/contamination, sorbent of pollutants from wastewater), renewable source of energy (biogas, bioethanol), and high-tech composite materials.
\end{abstract}

Keywords Cladophora $\cdot$ Chlorophyta $\cdot$ Ecology $\cdot$ Cultivation $\cdot$ Chemical composition $\cdot$ Application

\section{Introduction}

Macroscopic green algae are a highly diversified group and, because of their ability of fast spreading, they are considered to be pioneering organisms (Van den Hoek et al. 1995). Despite the common occurrence of macroscopic algae communities, information on the ecology of filamentous green

Izabela Michalak

izabela.michalak@pwr.edu.pl

Beata Messyasz

messyasz@amu.edu.pl

1 Department of Advanced Material Technologies, Faculty of Chemistry, Wrocław University of Science and Technology, Smoluchowskiego 25, 50-372 Wrocław, Poland

2 Department of Hydrobiology, Faculty of Biology, Adam Mickiewicz University in Poznan, Uniwersytetu Poznanskiego 6, Poznań 61-614, Poland algae in scientific literature is scarce and fragmentary. Freshwater macroalgae consist of filamentous forms (Cladophora, Oedogonium, Spirogyra), as well as algae forming net-like structures (Hydrodictyon), tube-like or laminar thalli (Ulva), as well as very complex thalli divided into distinct stems from which branches arise in whorls (Characeae) (Messyasz et al. 2015a). Macroalgae communities in the form of mats are mainly monospecies, formed most commonly by filamentous green algae from the genus Cladophora (Messyasz et al. 2015a; Pikosz and Messyasz 2015, 2016). Growth form closely associated with substratum occurs mainly in young thalli. Cladophora glomerata (L.) Kützing, which is dominant in salt- and freshwaters may create sparse and dense mats floating on the water surface during intensive growth.

Cladophora belongs to the group of macroscopic green algae with over 183 species (Munir et al. 2019). The occurrence of this annual filamentous macroalga is mainly due to the increasing content of nutrients (nitrogen and phosphorus) 
in the water. This nutrient enrichment results from the intensive agriculture (the use of mineral fertilizers), usage of detergents containing phosphorus, increased human populations, wastewater treatment plants etc. (Parker and Maberly 2000; Mihranyan 2011). Seasonal blooms of this alga constitute a serious environmental problem. To increase our capabilities for prediction of both the spread and cosmopolitan nature of Cladophora, detailed and relevant information on the ecology of the species is imperative. The biological and ecological characteristics of Cladophora are important predictors of its pioneer nature and consequent impact in native communities in connection with the eutrophication process. Based on literature data, the adaptive features underlying the vertical and spatial distribution of Cladophora and their implication for community ecology, various functional-form models, life history traits, and commercial use will be discussed.

In this review, we present also the possibilities of the turning of this environmental problem into an opportunity - using macroalgal biomass to manufacture products useful for humans. Therefore, distribution, ecology and metabolism, life history, population, harvesting, cultivation, chemical composition, and properties of biologically active compounds, as well as utilization of Cladophora species, are discussed in a broad context. Several applications of macroalgal biomass are highlighted, for example pharmaceutical, nutraceutical and cosmetic applications, fertilizers and biostimulants of plant growth, feed additives, indicators of environmental pollution, sorbents of toxic metal ions from wastewater, raw material for the production of biofuels, or high-tech composite materials.

\section{Classification}

Traditional systems of macroalgae are based on features such as morphology, cell biology, life history, and reproductive strategies. Chlorophyta (green algae) are the most common in freshwater ecosystems, especially species of the genus Cladophora Kützing (Higgins et al. 2008; Malkin et al. 2010; Young et al. 2010; Messyasz et al. 2015a).

Green algae have been classified into several taxonomic groups on the basis of a wide morphological diversity as well as molecular and ultrastructural characteristics. Silva (1982) describes three phyletic lines within phylum Chlorophyta: Chlorophyceae, Ulvophyceae, and Charophyceae. Diagnostic features assigned to the Ulvophyceae include among others terminal caps with a bilobed construction enclosing the proximal ends of the basal bodies (Van den Hoek et al. 1995; South and Whittick 1996; Lee 2008; Škaloud et al. 2018). In such an arrangement, the class Ulvophyceae contains eight orders: Ulotrichales, Ctenocladales, Ulvales, Acrosiphoniales, Cladophorales, Siphonocladales, Bryopsidales, and Sphaeropleales (Silva 1982). According to Pliński and Hindák (2012) after Starmach (1972), the order Cladophorales West had only one family Cladophoraceae (Hassal) emend. Wittrock was divided into six genera: Rhizoclonium Kützing, Spongomorpha Kützing, Chaetomorpha Kützing, Urospora Areschoug, Acrosiphonia J. Agardh, and Cladophora Kützing. However, currently, according to Guiry and Guiry (2020), the order Cladophorales Haeckel has three families: Cladophoraceae Wille (genera Cladophora, Rhizoclonium, Pseudorhizoclonium Kützing, Chaetomorpha), Pithophoraceae Wittrock (genus Aegagropila), and Pseudocladophoraceae Boedeker and Leliaert (genus Pseudocladophora Boedeker and Leliaert). The classification adopted here is as follows (Hanyuda et al. 2002; Soejima et al. 2009; Boedeker et al. 2010, 2012; Boedeker and Sviridenko 2012; Togashi et al. 2014; Guiry and Guiry 2020):
Empire: Eukaryota Chatton
Kingdom: Plantae Haeckel
Subkingdom: Viridiplantae Cavalier-Smith
Infrakingdom: Chlorophyta infrakingdom Cavalier-Smith
Phylum: Chlorophyta Reichenbach
Subphylum: Chlorophytina
Class: Ulvophyceae K.R. Mattox and K.D. Stewart
Order: Cladophorales Haeckel
Family: Cladophoraceae Wille
Genus: Cladophora Kützing (159 taxa)
Family: Phithophoraceae Wittrock
Genus: Aegagropila Kützing (8 taxa)
Family: Pseudocladophoraceae Boedeker and Leliaert
Genus: Pseudocladophora Boedeker and Leliaert (2 taxa)

Cladophora occurs in many diverse places and is known by many common names: blanket weed (English, (Kelly and King 2007)), grönslick (Swedish, (Tolstoy and Österlund 2003)), кладофара (Russian, Belarusian, Ukrainian), gałęzatka (Polish, (Starmach 1972)), žabi vlas (Czech), maurarykšte (Lithuanian), Seebälle (German), karevetikas (Estonian), vandhår (Danish), grønndusker (Norwegian), rotswier (Dutch), pelillo, espinaca de mar (Spanish), シオグサmarimo (Japanese), kai (Thai) (Pereira 2016).

\section{Taxonomy and morphology}

Due to morphological and phenotypical plasticity, many of filamentous algae are difficult to identify. Taxonomic criteria for the identification Cladophora genera include the following: thallus color, branching types, design and dimensions of the cell, the general structure of the plant, basal cells, and the shape of zoospores (Starmach 1972; Van den Hoek et al. 1995).

The genus Cladophora includes filamentous green algae, profusely, sparsely, or densely branched, and often taking a bushy, cushion-like or globular form (Van den Hoek et al. 
1995; Kelly and King 2007; Messyasz et al. 2015a, 2018a). Branches are located laterally below the top of the cell or apically (on the top of the cell). The thalli are attached to the ground (substratum) by a discoid holdfast formed from the cell membrane or branched rhizoids (rootlike filaments without vascular tissue) growing from the cells of the lower part of the thallus (Van den Hoek et al. 1995; Lee 2008; Pliński and Hindák 2012; Messyasz et al. 2015a, 2018a). Macroalgal filamentous thalli can also be unattached.

Filamentous thalli are made of cylindrical, indented by transverse walls, multinucleated cells (Lee 2008). There is a cuticle layer in the outer layers of the cell wall that gives the cell stiffness and mechanical resistance. The inner layer of the cell wall made of cellulose adheres to the protoplasm (Van den Hoek et al. 1995). The cell wall surface in Cladophora species is usually smooth, not covered by mucus, and can be overgrown by epiphytic algae.

The cells have a number of lamellar chromatophores that cluster into reticular formations in the layers of protoplasm near the cel wall (South and Whittick 1996; Lee 2008). They contain photosynthetic pigments common to all green algae: chlorophyll $a$, chlorophyll $b$, carotene, xanthophyll, which translate into the color of thallus being in shades from light yellowish to dark green (Van den Hoek et al. 1995). In poor light, the colors are always darker. The chromatophores contain numerous lenticular pyrenoids in which starch accumulates as a product of photosynthesis.

In the genus Cladophora, filament growth occurs by apical cell divisions followed by their elongation, or by cell division in the central parts of the thallus (intercalary cells). There is a third type of growth when the upper part of the thallus rises at the tops and the lower increases due to divisions downwards (Starmach 1972; South and Whittick 1996). Cell division in these green algae is very peculiar and is independent of nuclear division. The formation of transverse cell walls occurs inside the cell, dividing it into two parts (Van den Hoek et al. 1995).

Sexual reproduction occurs by isogamy with biflagellate isogametes. Cladophora gametes may develop parthenogenetically and undergo spontaneous diplodization, and poliploidy also can occur (Wik-Sjöstedt 1970). In the development cycle, they show isomorphic alternation of generations (Van den Hoek 1981, 1982), which means that sporophyte (diploid plant that forms spores) and gametophyte (plant generation that forms the gametes, usually haploid) are morphologically built the same. It has been noted that freshwater species Cladophora glomerata var. crassior (formerly Cladophora crispata) has a zygotic life cycle (Siddique and Faridi 1977) and Cladophora glomerata a gametic one (South and Whittick 1996). According to Van den Hoek et al. (1995), C. glomerata reproduces only by the asexual production of biflagellate zoospores and the formation of zoosporangia is favored by short-day conditions (16-h dark).
On the other hand, asexual reproduction takes place with the help of different shape zoospores, with two or four apical flagella (Van den Hoek 1981; Van den Hoek et al. 1995). Quite often only vegetative reproduction occurs in Cladophora by thallus fragmentation and runner formation. Under conditions unfavorable for growth, spore branches (thickened rhizoids and parts of the thallus) or thick-walled resting spore cells (akinetes) are produced (Lee 2008). Together with environmental conditions' improvement, the akinetes give rise to new Cladophora plants.

Morphological plasticity has been observed for most Cladophora species as indicated by many authors, e.g., Chudyba (1965), Van den Hoek (1963), Starmach (1972), and Van den Hoek et al. (1995). According to Whitton (1970), among Cladophora genera, C. glomerata, C. rivularis, and C. fracta are the most commonly found in eutrophic freshwater ecosystems. Pikosz and Messyasz $(2015,2016)$ described differences noted in the morphological structure of thallus and cells between three species of the genus Cladophora, dominating in the mats in which they occurred (Table 1). Cladophora glomerata thalli collected from stagnant reservoirs had numerous branches and reached about $20 \mathrm{~cm}$ in length, while those collected from flowing waters had few branches with the thallus reaching up to $1 \mathrm{~m}$ in length. The view of the whole C. glomerata thalli shows the dense branching (Figs. 1, 2).

Quantitative and qualitative analysis of basic protein amino acids in C. glomerata and C. fracta cells showed the presence of 18 amino acids (Pikosz et al. 2019). Research has shown a wide range of biochemical reactions of $C$. glomerata in a stressful environment. The arrangement of amino acids in individual green algae was very similar, the orders Thr (threonine- improves the generative development of plants), Ser (serine - necessary for chlorophyll synthesis), and Pro (proline - improves the generative development of plants and regulates water management in the cell) were different. In addition, among the tested algae, the highest content of pigments and phenolic compounds was found in $C$. glomerata cells. The content of chlorophyll $a$, chlorophyll $b$, and carotenoids in biomass of $C$. glomerata was almost twice as high as that in other green algae. Then, based on the prepared culture, the effect of secretions of one species on changes in the composition of amino acids of the other taxon was examined. The response of $C$. fracta and Rhizoclonium sp. was already visible at the lowest concentration of $C$. glomerata secretions, in particular the proline content in the cells changed. In response to the presence of $C$. glomerata secretions, the proline



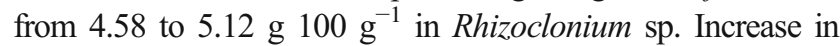
proline production, which is responsible for the osmotic regulation, was the response of filamentous green algae to environmental stress as previously indicated by Kaur and Asthir (2015). This confirms the concept suggesting the possibility of triggering algae (similar to plants) physiological and biochemical mechanisms of opposing the influence of a stress factor (Jones 1978; 
Table 1 Morphological characteristics of the most widespread species from the order Cladophorales. Main sources follow (Messyasz et al. 2015c; Pikosz and Messyasz 2015, 2016)

\begin{tabular}{|c|c|c|c|}
\hline \multirow{2}{*}{$\begin{array}{l}\text { Taxonomic } \\
\text { feature }\end{array}$} & \multicolumn{3}{|l|}{ Species } \\
\hline & $\begin{array}{l}\text { C. glomerata } \\
\text { (Poland) }\end{array}$ & $\begin{array}{l}\text { C. rivularis } \\
\text { (Poland) }\end{array}$ & $\begin{array}{l}\text { Aegagropila linnaei } \\
\text { (Poland) }\end{array}$ \\
\hline Color & Dark green & Light green & Yellowish to dark green \\
\hline $\begin{array}{l}\text { Thalli } \\
\text { length }\end{array}$ & To several meters & To several $\mathrm{cm}$ & To $10 \mathrm{~cm}$ \\
\hline $\begin{array}{l}\text { Thalli } \\
\text { appear- } \\
\text { ance }\end{array}$ & $\begin{array}{l}\text { Siphonocladous, incrusted, rough to the } \\
\text { touch }\end{array}$ & $\begin{array}{l}\text { Long, intertwining filaments with variable } \\
\text { diameter }\end{array}$ & $\begin{array}{l}\text { Balls, compact, or loose } \\
\text { Twisted filaments overgrown with rhizoids } \\
\text { and grow in different directions }\end{array}$ \\
\hline $\begin{array}{l}\text { Thalli } \\
\text { branches }\end{array}$ & $\begin{array}{l}\text { Pseudodichotomus type of branching; } \\
\text { Young - short, highly branched } \\
\text { Older-fewer, longer branches in the lower } \\
\text { part }\end{array}$ & Poorly branched & $\begin{array}{l}\text { Subterminal, lateral, opposite, and serial } \\
\text { insertion of densely branches (Van den } \\
\text { Hoek 1963) }\end{array}$ \\
\hline Forms & Attached and loosely floating & Loosely floating & Attached, unattached, floating \\
\hline Cells & $\begin{array}{l}\text { Double-layer cell wall. Its apical cell width is } \\
\text { (19-24)-(58-91) } \mu \mathrm{m} \text {, while the main } \\
\text { filament to } 150 \mu \mathrm{m} \text { (Starmach 1972). } \\
\text { Cells size range in the main axis } \\
\text { cylindrical cells, } 90-100 \mu \mathrm{m} \text { in diameter, } \\
\text { and } 160-240 \mu \mathrm{m} \text { long; branches } \\
40-70 \mu \mathrm{m} \text { in diameter and } 150-270 \mu \mathrm{m} \\
\text { long. Apical cells } 20-40 \mu \mathrm{m} \text { in diameter } \\
\text { and } 140-160 \mu \mathrm{m} \text { long (naw and win } \\
\text { 2011). The width of apical cell is } \\
37-54 \mu \mathrm{m} \text {, the main filament to } 100 \mu \mathrm{m} \text {, } \\
\text { pyrenoids } 3.0-6.4 \mu \mathrm{m} \text { in diameters, the } \\
\text { nucleus diameter } 4.6-8.5 \mu \mathrm{m} \text {, thickness } \\
\text { of the cell wall } 3-4 \mu \mathrm{m}\end{array}$ & $\begin{array}{l}\text { Diameter }<30 \mu \mathrm{m}(18-25) \text { cell in the } \\
\text { filament cylindrical, } 50-100 \mu \mathrm{m} \text { in } \\
\text { diameter, and } 300-440 \mu \mathrm{m} \text { long; cell wall } \\
\text { thin layer, chloroplast periphery, } \\
\text { reticulate, numerous discoid pyrenoids } \\
\text { and conspicuous (Naw and Win 2011). } \\
\text { Morphological variability: the main axis } \\
\text { continued to grow with cells being half } \\
\text { the diameter of the origin size. Cell } \\
38-76 \mu \mathrm{m} \text { in diameter and } 170-387 \mu \mathrm{m} \\
\text { long, cell wall } 3-7 \mu \mathrm{m} \text {; rounded apical } \\
\text { cell }(\mathrm{W} / \mathrm{L} 35 / 320 \mu \mathrm{m}) \text {, number of nucleus } \\
4.5-8.0 \mu \mathrm{m} \text { and pyrenoids } 10 \mu \mathrm{m} \text { in } \\
\text { diameter }\end{array}$ & $\begin{array}{l}\text { Irregular cell shape and variable cell } \\
\text { dimension apical cells are } 30-70-\mu \mathrm{m} \\
\text { width, main axis cells are } 125-200-\mu \mathrm{m} \\
\text { width (Starmach 1972). Apical cell } \\
\text { rounded 45-71- } \mu \mathrm{m} \text { width and main axis } \\
\text { cells are } 136-363-\mu \mathrm{m} \text { width }\end{array}$ \\
\hline $\begin{array}{l}\text { Creating a } \\
\text { mat }\end{array}$ & Single-species and multi-species; dense mat & Single-species and multi-species; dense mat & Single-species; compact/loose balls \\
\hline $\begin{array}{l}\text { Confused } \\
\text { with }\end{array}$ & Rhizoclonium spp. & Rhizoclonium, Chaetomorpha linum & No data \\
\hline
\end{tabular}

$W$ width, $L$ length

Chapin 1991). At low stress levels, proline can play a protective role due to the possibility of using it for the synthesis of proteins or chlorophyll. It was noticed that significant changes in the composition of amino acids in C. glomerata, which dominates and is the most abundant in aquatic ecosystems, occurred only under the influence of the highest concentrations of $C$. fracta and Rhizoclonium sp. secretions; however, the $C$. glomerata reaction was at a lower level, not comparable to changes that were noticed in other taxa. The biochemical reaction of $C$. glomerata shows the strategy of this species (more resistant to stress), which consists in taking over the dominance of the community or monopolizing the surface of the water surface by creating single or multi-species mats (Pikosz et al. 2019).

\section{Ecology}

Deforestation of many rivers, streams, lakes, and pond catchments as well as conversion of significant areas for agriculturae, increased fertilization, and intensive animal husbandry, also domestic sewage, are the causes of strong eutrophication of the Polish water habitat. Degraded waters contain large amounts of $\mathrm{N}, \mathrm{P} \mathrm{K}, \mathrm{Ca}$, and $\mathrm{Na}$, which favor the development of specific micro- and macroalgae communities. Especially noticeable are macroalgae communities, which often occur in large quantities in the form of anchored (Vaucheria sp., Tribonema sp., Ulothrix sp., Rhizoclonium sp.) or floating mats (Cladophora spp., Ulva flexuosa, Oedogonium sp., Spirogyra sp., Mougeotia sp., Hydrodictyon reticulatum) that accumulate large amounts of biomass. In the hydrobiological literature, one can find mainly works in which the authors only mention the presence of thread-like algae in aquatic ecosystems and pay attention to the few and fragmentary information about the thread-algae ecology. The distribution of filamentous green algae such as C. glomerata, Spirogyra sp., and Oedogonium sp. has attracted the attention of many limnologists, but only a few have written about the ecology of their mats (Van den Hoek 1963; Higgins et al. 2005, 2006, 2008; Messyasz et al. 2015a, 2018a; Prazukin et al. 2018). Available information on the 
Fig. 1 View of the whole Cladophora glomerata thalli showing the dense branching (photos by M. Pikosz): a overall view of profusely branched

Thallus; b lateral branch causing a change in the direction of the main filament growth; c number of branches in apical part of thalli; d apical cell with primary side branch; e thallus with reticulate chloroplast and epiphytic diatoms on the surface of cell wall


Fig. 2 View of the whole Cladophora species thalli showing branching (photos by M. Pikosz): a Cladophora rivularis; b Cladophora fracta

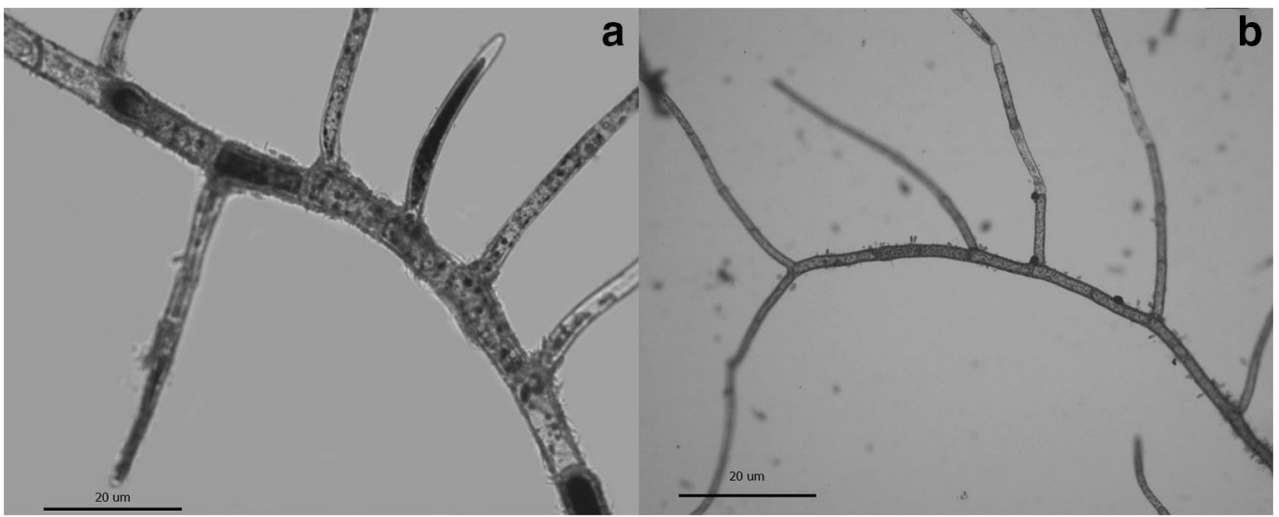


structure and role of algae mats is too general and primarily concerns marine ecosystems. Ecological research on macroalgae mats from freshwater ecosystems was conducted mainly by specialists from India (Khanum 1982) and Canada (Higgins et al. 2008), while incomplete information about the morphological forms of $C$. glomerata from the river comes from the 1960s (Chudyba 1965) and from recent years (Messyasz et al. 2018a, 2018b; Prazukin et al. 2018). Moreover, the characteristics of the interaction between micro- and macroalgae due to shading resulting from the occurrence of dense mats have been studied by Sundbäck and McGlathery (2005), but also applies to the marine ecosystem.

Morphometric structure of thallus, seasonality of occurrence, and production of a large amount of biomass of filamentous algae are closely related to habitat conditions (Van den Hoek et al. 1995; Higgins et al. 2005, 2006, 2008; Pikosz et al. 2017). The relationship between habitat factors and the distribution of Cladophora species indicated that water depth, chloride, orthophosphate, nitrate, total dissolved salts, and chlorophyll $a$ content in water are key parameters determining the composition of filamentous algae communities. Ecological niches of filamentous green algae and the functioning of the structure of mats are described in detail in the work of Pikosz et al. (2017). The response of filamentous algae (C. glomerata, C. rivularis, $C$. fracta) to basic abiotic factors was determined using GAM models. Within the habitat factors, the following were considered: temperature, electrolytic conductivity, total amount of solute and the content of chlorides, orthophosphates, nitrates, and ammonium ions (Table 2). The response curves for the most common taxa showed diversity in their niches.

Different evidence for the temperature control of distribution comes from laboratory studies on the effects of temperature on the life history and the tolerance of species to different ranges of temperatures (Cambridge et al. 1987). Combination of temperature and photoperiodic responses of particular species can explain geographical distribution patterns. However, it should be emphasized that due to the morphological plasticity of some species, there is often the problem with the correct identification and, as a consequence, may lead to errors in geographic distribution. For this reason, the description of ecological conditions was based primarily on information for the temperate zone.

\section{Water temperature}

Higgins et al. $(2005,2008)$ showed that Cladophora species have a wide tolerance range for temperature changes. According to Stewart and Lowe (2008), temperature range for Cladophora is $5-23{ }^{\circ} \mathrm{C}$, whereas the decline in biomass by $C$. glomerata during the summer can be related to temperature and low nutrients - an inability to maintain dominance above $23.5^{\circ} \mathrm{C}$ (Wong et al. 1978). There is also a suggestion that cool spring temperatures limit the potential growth of this species. Moreover, significant differences in preference for a specific temperature range were found for species belonging to Cladophora, such as C. glomerata, C. rivularis, and C. fracta, which developed in different habitat conditions and were characterized by high tolerance to temperature changes. For $C$. glomerata, the curve had a monotonous decreasing function and for other species of this genera the curve was increasing (Pikosz et al. 2017).

\section{Light}

The maximum depth of colonization is connected with water clarity (Higgins et al. 2008). The study of Pärnoja et al. (2014) about the photosynthetic production of macroalgae at a reduced salinity indicates that in shallow water despite a good light exposure C. glomerata can still be strongly light-limited.

\section{Salinity}

The low species richness of the Baltic macroalgae communities compared to those of the Atlantic coast is closely related to the limit of these species to tolerance to low salinity (Snoeijs 1999; Eriksson and Johansson 2005). According to Pikosz et al. (2017), significant models of response to the content of $\mathrm{Cl}^{-}$ions in the form of monotonic curves were fitted to 5 out of 13 taxa analyzed, and another 5 had a unimodal distribution. The salinity range for $C$. glomerata in Polish aquatic ecosystems is at the level $40-80 \mathrm{mg} \mathrm{Cl}^{-} \mathrm{L}^{-1}$. The source of chlorides in the studied aquatic ecosystems was surface runoff from the fields. Representatives of the Zygnemataceae were present in water with a lower content of chlorides (decreasing monotonic curve), biogenic compounds, and total amount of dissolved salts and in water with lower electrolytic conductivity (unimodal curve with optimum development at low values). Oedogonium capillare and Cladophora rivularis, on the other hand, preferred waters with a high concentration of chlorides (growing monotone curve).

\section{Nutrients}

Many studies have documented the association of $C$. glomerata with high nutrient inputs (Bojorge-García et al. 2010). For C. glomerata, the values of electrolytic conductivity and total amount of solutes in which the optimum development was set were determined at the level $300-500 \mu \mathrm{S} \mathrm{cm}^{-1}$. It has been shown that species richness does not increase as the concentration of nutrient compounds increases along the entire gradient. Only a few species are able to grow in an environment with a high content of nutrients. Cladophora glomerata was characterized by unimodal distribution, while Rhizoclonium $\mathrm{sp}$. and Vaucheria sp. had a monotonic growth curve in response to nitrogen compounds (Pikosz et al. 2017). The presence of $C$. glomerata is strongly correlated with 
Table 2 Ecological characteristics of the most widespread species from the order Cladophorales. Main sources follow (Messyasz et al. 2015b; Pikosz and Messyasz 2015, 2016)

\begin{tabular}{|c|c|c|c|}
\hline \multirow{2}{*}{$\begin{array}{l}\text { Freshwater } \\
\text { macroalga }\end{array}$} & \multicolumn{3}{|l|}{ Ecological determinants } \\
\hline & Habitat preferences & Place of occurrence & Accompanying species \\
\hline $\begin{array}{l}\text { C. glomerata } \\
\text { (Poland) }\end{array}$ & $\begin{array}{l}\text { Cosmopolitan species, is } \\
\text { common in marine and } \\
\text { littoral ecosystems } \\
\text { (estuaries), saline and } \\
\text { freshwater, running } \\
\text { waters, and lakes/ponds. } \\
\text { So far not recorded in } \\
\text { polar waters. } \\
\text { Habitat factors: water } \\
\text { temperature }\left(17-29{ }^{\circ} \mathrm{C} \text { ), a }\right. \\
\text { neutral pH (pH }>8 \text { ), the } \\
\text { availability of light (mean } \\
\text { 3000 LUX), the content of } \\
\text { nutrients, prefers clear } \\
\text { waters with color values } \\
\text { not above } 30 \text { mg Pt } \mathrm{L}^{-1} \\
\text { (Johansson } 1982 \text { ). }\end{array}$ & $\begin{array}{l}\text { Common in Polish Baltic } \\
\text { Sea: Gdańsk Gulf(Kornaś } \\
\text { et al. 1960; Pliński and } \\
\text { Florczyk 1984; Pliński } \\
\text { and Jóźwiak 2004), east } \\
\text { coast of the Pomorska } \\
\text { Gulf (Rosińska et al. } \\
\text { 2013), Sopot (own study); } \\
\text { mountain rivers and } \\
\text { streams: Skawa (Chudyba } \\
\text { 1965), Lubogosz } \\
\text { (Starmach 1969); lowland } \\
\text { rivers: Nielba, Wełna, } \\
\text { Mogilnica, Samica } \\
\text { Stęszewska (own study); } \\
\text { lakes: Roś (Pieczyńska } \\
\text { and Tarmanowska 1996), } \\
\text { Durowskie, Zbiornik } \\
\text { Maltański, and different } \\
\text { types of small water } \\
\text { bodies (own study). }\end{array}$ & $\begin{array}{l}\text { Oedogonium, } \\
\text { Stigeoclonium, } \\
\text { Microspora, Mougeotia, } \\
\text { Spirogyra (Pieczyńska } \\
\text { and Tarmanowska 1996); } \\
\text { Hildenbradtia rivularis } \\
\text { (Starmach 1969)-in the } \\
\text { mountain streams, the } \\
\text { lowland rivers; } \\
\text { Enteromopha compressa, } \\
\text { E. flexuosa subsp. } \\
\text { flexuosa, E. linca } \\
\text { (Rosińska et al. 2013)-in } \\
\text { the Baltic Sea; } \\
\text { In the littoral zone among } \\
\text { submerged aquatic plants. }\end{array}$ \\
\hline $\begin{array}{l}\text { C. rivularis } \\
\text { (Poland) }\end{array}$ & $\begin{array}{l}\text { Typical for stagnant and } \\
\text { turbulent water. } \\
\text { Habitat factors: development } \\
\text { in eutrophic condition, } \\
\text { pH }>7 \text {, conductivity } \\
\sim 1000 \mu \mathrm{S} \mathrm{cm} \text { cm }^{-1} \text {, total } \\
\text { dissolved substance } \\
440 \mathrm{mg} \mathrm{L}^{-1} \text { and chlorides } \\
550 \mathrm{mg} \mathrm{L}^{-1} \text {. }\end{array}$ & $\begin{array}{l}\text { Common in Silesia } \\
\text { Region-Strzelin } \\
\text { (Starmach 1972). } \\
\text { Forming dense mat in } \\
\text { Konojad Pond } \\
\text { (Wielkopolska Region). }\end{array}$ & $\begin{array}{l}\text { Cladophora glomerata } \\
\text { among Typha angustifolia } \\
\text { (Van den Hoek 1963); } \\
\text { co-existed with other } \\
\text { Cladophora species (Naw } \\
\text { and Win 2011)_in } \\
\text { streams; Oedogonium sp., } \\
\text { algal-cyanobacterial } \\
\text { metaphyton-in mid-field } \\
\text { pond. }\end{array}$ \\
\hline $\begin{array}{l}\text { Aegagropila } \\
\text { linnaei } \\
\text { (Poland) }\end{array}$ & $\begin{array}{l}\text { Cosmopolitan species, is } \\
\text { common in freshwater } \\
\text { and brackish water (Van } \\
\text { den Hoek 1963), } \\
\text { eutrophic freshwater lakes } \\
\text { (Starmach 1972). It can } \\
\text { occur in several different } \\
\text { growth forms, depending } \\
\text { on environmental } \\
\text { conditions (Boedeker and } \\
\text { Immers 2009). }\end{array}$ & $\begin{array}{l}6 \text { confirmed locations in } \\
\text { Poland: Gulf of Puck, } \\
\text { Jantar, Rewa, Sopot, lake } \\
\text { Miedwie near Szczecin, } \\
\text { Lake Tatarak near } \\
\text { Legnica, lake } \\
\text { Wierzbinickie near } \\
\text { Myślibórz (Pliński and } \\
\text { Jóźwiak 2004; Boedeker } \\
\text { et al. 2010). }\end{array}$ & $\begin{array}{l}\text { Due to ability to } \\
\text { moving/rolling not report- } \\
\text { ed the presence of other } \\
\text { macroalgae. Mathiesen } \\
\text { and Mathiesen (1992) } \\
\text { described the } \\
\text { Aegagropiletum } \\
\text { benthonicum association } \\
\text { composed of } \\
\text { C. aegagropila } \\
(=\text { A. linnaei), attached or } \\
\text { forming loose-lying balls } \\
\text { from Gulf of Bothnia. }\end{array}$ \\
\hline
\end{tabular}

high water fertility, i.e., the content of chlorophyll $a$, nitrates, and phosphates. The presence of $C$. fracta depended on such factors as the content of total dissolved salts and the electrolytic conductivity of water, whereas in the mid-field pond $C$. rivularis together with O. capillare, Microspora sp., Spirogyra sp., and Mougeotia sp. occurred in water with a high content of chlorides and sulfates (Pikosz and Messyasz 2016). Phosphorus was determined to be the primary growth-limiting nutrient for Cladophora growth (Stewart and Lowe 2008). In eastern Lake Erie (North America), mean soluble reactive phosphorus ranged from 0.9 to $3.5 \mu \mathrm{g} \mathrm{L}^{-1}$ during the spring-summer growing period (Higgins et al. 2006, 2008).

\section{Life history}

Cladophora glomerata is a ephemeral species and has long continuous periods of spore production through the growing season and it has colonized the substratum in large quantities early in the succession. However, propagation of $C$. glomerata in Colorado River environment takes place by fragmentation or 
expansion of the holdfast (Blinn et al. 1998). Zoospore production in C. glomerata occurs at temperatures $>16^{\circ} \mathrm{C}$ (Hoffmann and Graham 1984) and because the waters in the river are much cooler than its optimum, the temperature effectively inhibits this process. Furthermore, under the high flow, C. glomerata can be replaced by other filamentous green algae as for example Zygnematales or Ulotrichales. Eriksson and Johansson (2005) observed that the favorite sediment conditions for both spore attachment and growth of Cladophora at $8 \mathrm{~m}$ and $16 \mathrm{~m}$ of Swedish east cost allow for development several generations during the year. With such favorable habitat conditions, the continuous spore production can take place from April to the end of August and then follows the formation of large amounts of over-wintering resting stages (Wallentinus 1979; Kiirikki and Lehvo 1997).

\section{Occurence and distribution}

Van den Hoek (1963) has reviewed in detail the history of the Cladophora group in Europe. The Cladophora genus consist of about 159 species (Guiry and Guiry 2020). Based on initial data provided by van den Hoek (1963), Starmach (1972) distinguished species most often found in freshwater ecosystems. According to this, fifteen taxa can be differentiated, based on the development in freshwaters: Cladophora aegagropila (L.) Rabenh. (=Aegagropila linnaei), C. basiramosa Schimdle, C. cornuta Brand, C. fracta var. fracta (Mull. Ex. Vahl) Kütz., C. fracta var. intricata (Mull. Ex. Vahl) Kütz., C. globulina (Kütz.) Kütz., C. glomerata var. glomerata (L.) Kütz., C. glomerata var. crassior (L.) Kütz., C. hutchinsiae (Dillw.) Kütz., C. kosterae Hoffm. \& Tild., C. okamurae (Ueda) Hoek, C. pachyderma (Kjellm.) Brand, C. rivularis (L.) v.d. Hoek, C. rupestris (L.) Kütz., C. sterrocladia Skuja, and C. surera Brand. At the same time, in the littoral zone of the sea, the following were noted: Cladophora aegagrophila (L.) Rabenh., C. albida (Nees) Kütz., C. basiramosa Schmidle in Wittrock et Nordstedt, C. dalmatica Kütz., C. fracta (O.F. Muller ex Vahl) Kütz., C. glomerata (L.) Kütz., C. humida Brand, C. pygmaea Reinke, C. rupestris (L.) Kütz., C. sericea (Hudson) Kütz., C. vadorum (Ares.) Kütz., and C. vagabunda (L.) Hock.

According to van den Hoek et al. (1995) and Boedeker et al. (2010), species of the genus Cladophora are the globally most widespread freshwater macroalgae. For example, Aegagropila linnaei was recorded from 283 locations in freshwater and brackish waters (Pliński and Jóźwiak 2004; Boedeker et al. 2010). However, for species of the genus Pseudocladophora, the range of occurrence covers mainly the Asia region seashores (van den Hoek and Chihara 2000; Hanyuda et al. 2002; Yoshii et al. 2004; Coppejans et al. 2005; Titlyanova et al. 2014; Titlyanov et al. 2015, 2019; Yoshida et al. 2015). Another species, Cladophora vagabunda, is common along all temperate and tropical seashores (Van den
Hoek et al. 1995). Studies on algae communities in water reservoirs in the Algeti National Park (Georgia) have shown the presence of four species of the genus Cladophora: C. canalicularis (L.) Kütz., C. globulina, and the widespread in low streaming water $C$. fracta and $C$. glomerata (Barinova et al. 2011).

Cladophora species belong to the epiphytic algae that are attached by a properly formed cell (discoid holdfast) to the substrate, which can be the surface of stems of aquatic plants, threads of other algae, animal shells, or abiotic surface (stones, wood) immersed in water. As typical settled plants in younger developmental stages, they are attached to the substratum. Very often the thallus tears from the substratum (e.g., during insolation), floats in water, and creates wadded clusters that are single or multi-species (Kelly and King 2007; Messyasz et al. 2018a) (Fig. 3, Table 2).

Cladophora glomerata is a very common freshwater alga, which grew very intensively on various substrates (rock, bedrock, boulder, cobble, gravel, wood dock, vascular plants, Dreissena shells), and for example to a depth of $10 \mathrm{~m}$ in the water column of Lake Erie throughout the period from 1865 to 2006 (Stewart and Lowe 2008). With the increase in eutrophication, filamentous cyanobacteria appeared, which reduced the occurrence Cladophora in Lake Erie.

Species of the genus listed below belong to the group of commonly reported filamentous algae in Poland: Cladophora (consisted 30\% among all studied sites), Spirogyra (16\%), Oedogonium (11\%), Ulothrix (8\%), Vaucheria (7\%), Mougeotia (7\%); the remaining 20\% consisted of taxa from Rhizoclonium, Microspora, Bulbochaete, Draparnaldia, Stigeoclonium, Hydrodiction, Zygnema, Sirogonium, and Tribonema genus. They most frequently inhabited rivers $(38 \%)$, streams $(12 \%)$, ponds $(20 \%)$, and lakes $(13 \%)$ (Pikosz and Messyasz 2016). In flowing waters, species of Cladophora and Ulothrix were most common, and in the ponds-Cladophora and Spirogyra. The area of monitoring the taxonomic and ecological diversity of filamentous green algae communities included mid-field and natural ponds; artificial reservoir in the city; natural, shallow lakes; rivers; and estuaries. Differences between aquatic ecosystems were visible in terms of physico-chemical parameters of water and the taxonomic composition of algae. Small water reservoirs can often constitute biodiversity refuges because they are also characterized by the highest species richness and the highest share of rare species among various types of freshwater habitats (Scheffer et al. 2006; Ożgo 2010).

\section{Population and community structure}

For thalli that create mats, movement of water itself is very important as it can be slow and light or turbulent. Water as a carrier strength can move algae biomass in the water surface 
Fig. 3 Massive development of filamentous green algae forming mats from inland and marine waters (photos by B. Messyasz): a long filaments of Cladophora glomerata in shallow Lake Oporzynskie; b Cladophora glomerata in the natural field pond; c filaments of Cladophora glomerata in the littoral zone of Lake Zbaszynskie; d Cladophora sp. growing on stones on the coast of the Baltic Sea; e flocs of Cladophora rivularis in Nielba river in Wagrowiec (Poland)
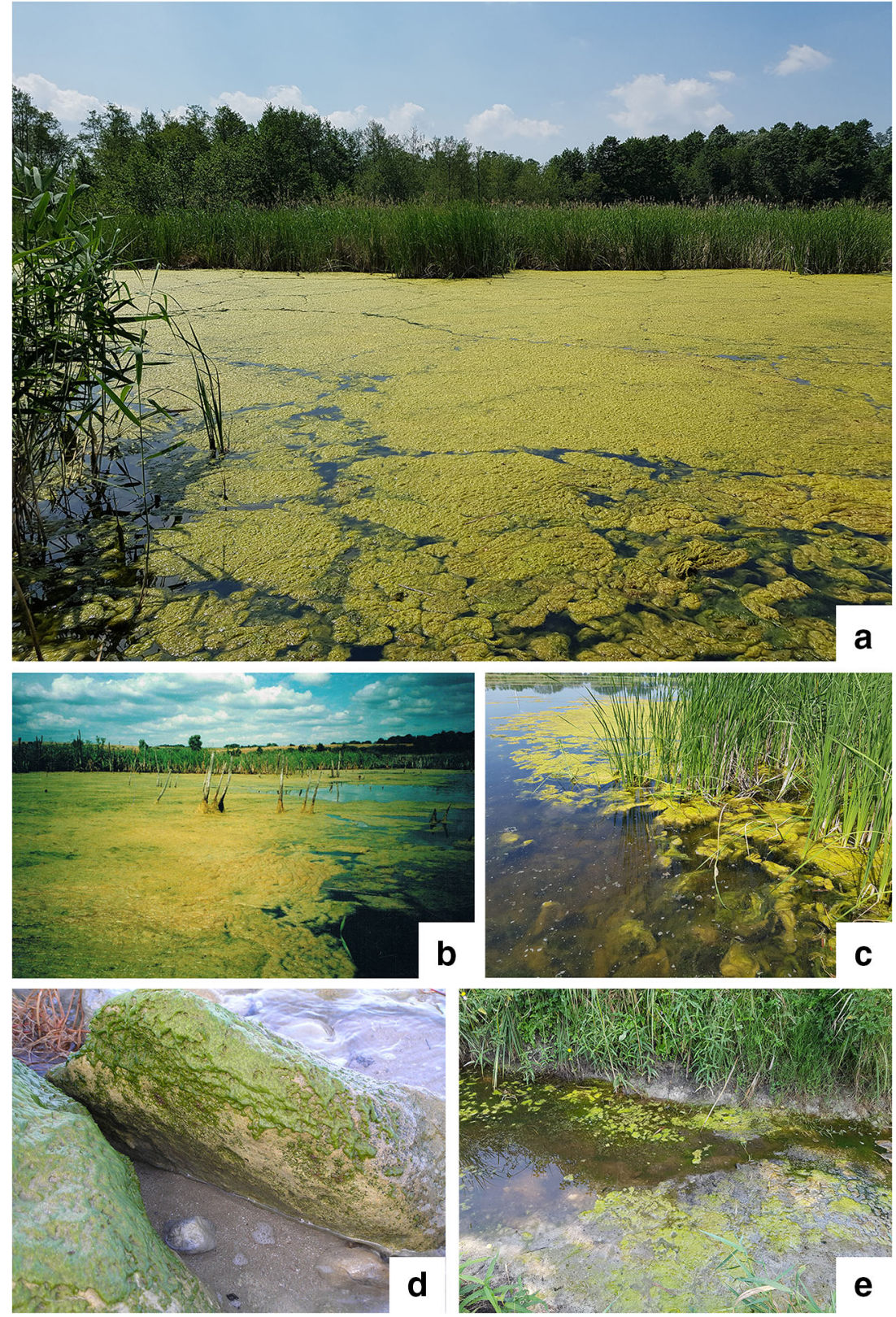

layer shaping its structure (loose, dense) and layer of occurence (pelagial, litoral). The mat structure understood as the way of spatial distribution of individuals (thalli) points to spatial organization and helps define not only purity of the material (homogenous, mixed, with admixture of macrophytes), but also harvest efficiency (quantity of harvest). Biomass, understood as the mass of individuals of given species per unit of area or volume, depends mainly from seasonality of its occurrence and environmental factors which enable colonization in new places. Cladophora glomerata has low light and temperature requirements, especially in the first phase of growth, hence its early development in spring in conditions of low temperature to create mats before the start of vegetative season (Pikosz et al. 2017). This strategy helps it to successfully compete with submerged plants for nutrients in water and spatial surface. Forms of $C$. glomerata which float on the water surface are dependent mainly on water chemistry. The optimal chemical composition of water for this species which allows increase of the quantity of filaments in mats and increase of the mat area includes high concentrations of phosphates and ammonium nitrate (stimulation of growth of thalli in length), and low concentrations of sodium chloride (high concentrations inhibit growth of thalli in length) (Pikosz and Messyasz 2016). In ponds and shallow lakes, C. glomerata mats are big enough to obtain a homogenous macroalgal biomass on the level of ca. $4 \mathrm{~kg}$ wet weight $\mathrm{m}^{-2}$.

The term "mat" is connected with filamentous macroscopic algae floating freely on the water surface or attached to the 
bottom (Saunders et al. 2012). According to Messyasz et al. (2018a), Cladophora mat formations can be divided into the following: (i) free-floating mats - taking shapes of flocs, mats or felts, tufts, clouds; (ii) attached to the bottom - upright growth forms (aligned), bush-like structures; (iii) overgrowing the entire water column - includes both free floating and attached forms. Moreover, filamentous thalli might overgrow each element that can serve as a pillar, e.g., submerged water plants. Diversification of mat shapes can occur also because of hydrodynamic conditions of the given water ecosystem, even when concerning the same macroalgal species (Fig. 4). The architectural diversity of macroalgal mats in terms of structure applies even to small aggregations in the very shallow littoral zone of ponds (Fig. 5). Cladophora thalli can float in the form of small clouds or as a result of water movments that create a mix-up with hydromacrophyte fragments. Aegagropila linnaei (syn. C. aegagropila) occurs in both brackish and freshwaters, and its thalli is shaped as unattached ball form.

Based on the mat, which occupied over $95 \%$ of the surface of the eutrophic Lake Oporzyńskie (Poland), a detailed study of the structure of dense, single-species mat was carried out in the vertical (surface zone, middle, bottom) and horizontal (edge zone and open water column) profile. In the horizontal profile, the biological, chemical, and physical parameters of the water did not show statistically significant differences except temperature, PAR radiation, and turbidity. The biometric parameters of $C$. glomerata thalli collected from the horizontal profile were also similar to each other. In contrast to the lack of changes in the spatial approach, there were significant changes in the vertical profile. The difference in water temperature at the surface and at the bottom was $6^{\circ} \mathrm{C}$, anaerobic conditions began to prevail at a depth of $130 \mathrm{~cm}$, but an intense fall in dissolved oxygen was already recorded at a depth of $50 \mathrm{~cm}$ below the water surface. The presence of a dense mat caused statistically significant changes in the tested physical and chemical indicators of water in the vertical profile $(0$ $2 \mathrm{~m})$. In addition, significant changes in the structure of C. glomerata cells collected in the vertical profile were noted. With depth, the pirenoid diameter increased and the cells were smaller. The content of chlorophyll $b$ and carotenoids in the thallus also changed. The pigment content in the thallus increased with depth. Increased starch storage in pyreneids was a cell response to stress factors. The developed results allow to better understand the role of filamentous green algae as bioindicators in water monitoring (Pikosz et al. 2017; Messyasz et al. 2018a).

Cladophora glomerata, as the only species of homogenous macroalgae mass development, is able to achieve high biomass in shallow water bodies in a short time. In Poland, this species forms its highest biomass concentration in two periods (Pikosz et al. 2017): spring (April-June) and autumn (SeptemberOctober), what confirms its strong response to colder water and also the possibility of harvesting biomass for several
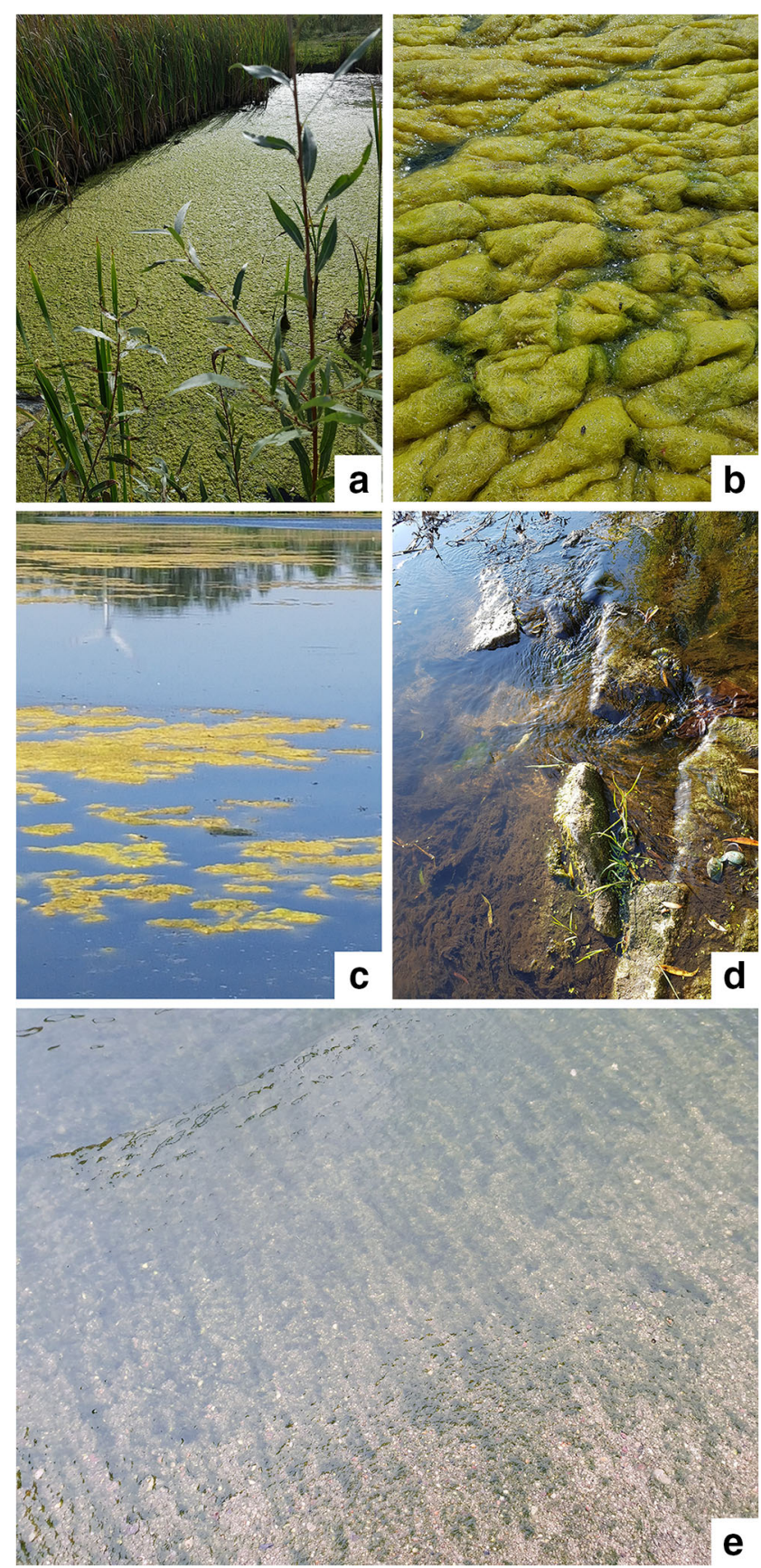

Fig. 4 The diverse in size and architectural shape species of Cladophora mats in various aquatic ecosystems (photos by B. Messyasz): a short and delicate filaments of Cladophora fracta in the artificial city pond; $\mathbf{b}$ a densely packed patch of very long filaments of Cladophora glomerata in Lake Oporzynskie; c small aggregations of Cladophora glomerata thalli in shallow Lake Oporzynskie (cloud-shaped mats); $\mathbf{d}$ loosely attached to the stones Cladophora glomerata and Cladophora rivularis with silty detritus among the filaments in Nielba River; e an example of an marine form of the thalloid alga Cladophora sp. creating large surface patches on the coast of the Baltic Sea

months a year. Such a phenomenon is consistent with the model example of mass appearances of Cladophora to $10 \mathrm{~m}$ in the water column in Lake Erie (Higgins et al. 2005, 2006; Stewart and Lowe 2008) and in the Laurentian Great Lakes (North 
Fig. 5 The diverse in size and species of Cladophora

macroscopic appearance in various aquatic ecosystems (photos by B. Messyasz): a freefloating mats of Cladophora globulina taking shapes of flocs in a drainage ditch; $\mathbf{b}$ a small loosely packed filaments of Cladophora fracta in small and shallow eutrophic pond; $\mathbf{c}$ a small cloud of Cladophora glomerata mixed with Cladophora rivularis in shallow garden pond; $\mathbf{d}$ a looselying ball of Aegagropila linnaei (syn. C. aegagrophila) from western part of the gulf of Gdansk
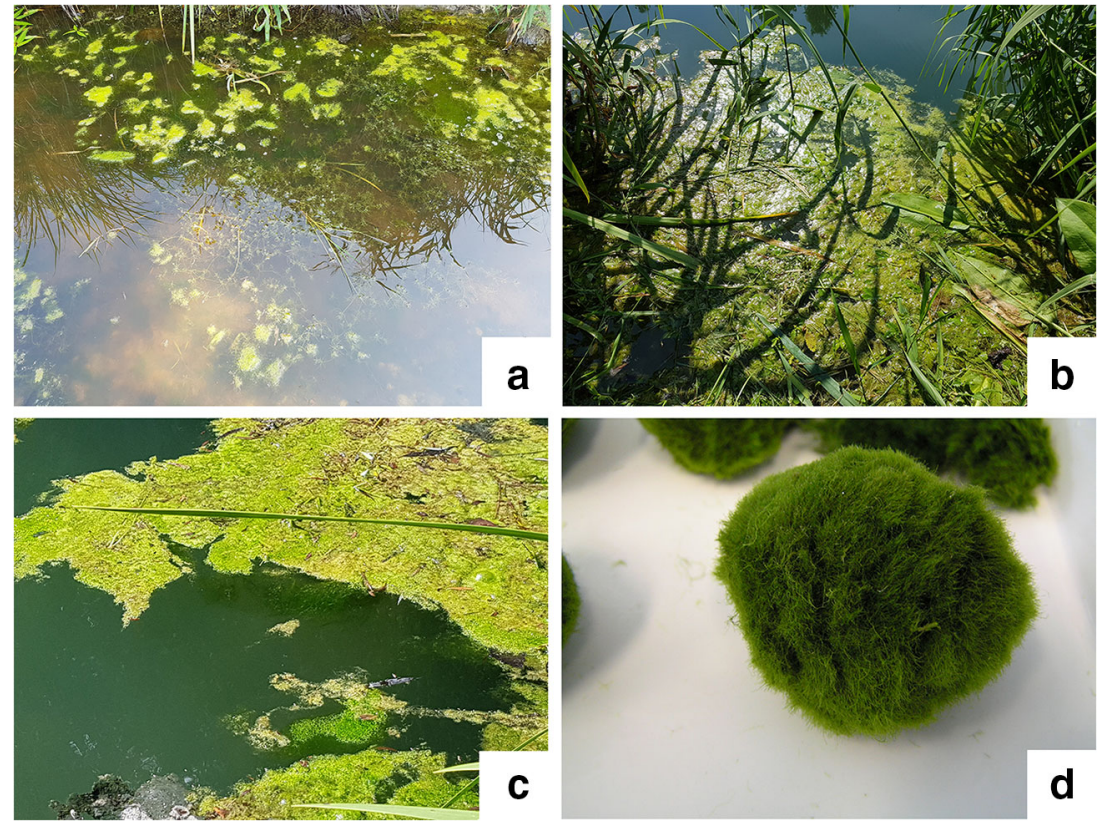

America) (Higgins et al. 2008). In all cases, the lowest biomass of Cladophora thalli were noted from December to April. For other freshwater species of macroalgae, optimum development is limited only to a few weeks, making it difficult to accurately plan the collection of biomass. It seems that the impact of environmental factors on the size of freshwater macroalgae biomass is higher than that of the marine ecosystem, which adds an additional factor of high variability and seasonality of harvest. A lack of repeatability in the development of the same amount of biomass in natural aquatic ecosystems can negatively affect subsequent economic aspects.

Mats can have a very complex vertical structure, where subsequent layers are also easy to indicate in color. Such a unique phenomenon occurs in small hypersaline Lake Chersovesskoye (Crimea, Russia) where the range of salinity varies in range from 35 to $360 \mathrm{~g} \mathrm{~L}^{-1}$ (Prazukin et al. 2018). The dense floating filamentous green algae mats are observed with domination of Cladophora species: C. vadorum (Aresch.) Kütz., C. siwaschenis Mayer, and C. echinus (Biasol.) Kütz. Cladophora mats occupied almost the entire water area of this lake. In the vertical structure of the mat, two or three layers differing in color were detected: (i) at the top occurrs crust of algae with layer of mineral salts; (ii) next in the middle is the thick layer with varied in size caverns; (iii) and the third layer is formed by decaying macrophytes. Interestingly, various levels of this mat were inhabited by numerous animals. This marine Cladophora beds provided habitat for a diverse group of animals including Orchestia gammarellus Pallas, O. mediterranea Costa, species of Coleoptera, Cletocamptus retrogressus Shmankevich, and Ostracoda Eucypris mareotica Fischer.
The mats next to the animal refuge are also a source of food for them. In the eutrophic Lake Crosemere (England), C. glomerata colonizes stones in the littoral zone for April onwards, developing a dense community in summer. Due to inter-species competition, it is often replaced by galleybuilding caddis larvae (Tinodes waeneri L.) (Harrison and Hildrew 2001). However, in rivers and spring-fed streams throughout Georgia and Alabama, frequently, C. glomerata co-occurs with red macroalgae: Batrachospermum helminthosum Sirodot (syn. Batrachospermum confusum (Bory) Hassall); Boldia erythrosiphon Herndon; Kumanoa holtonii Vis, Necchi, Chiasson, and Entwisle; Paralemanea annulata (Kütz.) Vis and Sheath and Tuomeya americana (Kütz.) Papenfuss. In these ecosystems with large amounts of C. glomerata biomass, crayfish showed a preference for grazing it, but when the population decreased, they switched to feed on the red alga Boldia (Goodman and Hay 2013).

Pikosz and Messyasz (2015) studied seasonality of filamentous algae occurrence and co-occurrence in small, natural, and artificial water bodies. In both types of ponds, there were metaphyton communities (green algae-cyanobacterial mats), which were present from spring until autumn. The metaphyton of the natural pond was dominated by representatives of Cladophorales and Oeodogoniales, while in the artificial pond Cladophorales and Zygnematales. In total, 12 taxa were determined in both ponds (11 in mid-field, 9 in artificial), of which 5 taxa occurred simultaneously in both locations (Ulothrix variabilis, Tribonema aequale, Oedogonium spp., Spirogyra spp., and Mougeotia sp.). The mid-field pond was characterized by a higher biodiversity of filamentous algae than the artificial pond. In both studied ecosystems, seasonal variability in the 
taxonomic composition of metaphyton was observed. In early spring, at lower water temperatures (up to $10{ }^{\circ} \mathrm{C}$ ), taxa of the Tribonema and Ulothrix dominated and were accompanied by representatives of Zygnematales. In the next phase, from May to August, the species structure of the community was converted into species of Cladophora and Oedogonium. Cladophora rivularis dominated in the natural pond, while $C$. fracta dominated in the artificial pond. Species of Cladophora dominated studied aquatic ecosystems, with mostly $C$. glomerata showing a clear dominance advantage over other filamentous algae species. The appearance, disappearance, and dominance of individual taxa is associated with life strategy and relates to the reaction of algae to changes in habitat factors, for example, water temperature, $\mathrm{pH}$, or electrolytic conductivity. In the mid-field pond, the $\mathrm{pH}$ of the water was up to 10.16 , while in the artificial reservoir the maximum $\mathrm{pH}$ was 8.75 with three times lower electrolytic conductivity. According to Fairchild et al. (1989), Cladophora occurs in neutral waters, while Oedogonium and Spirogyra prefer alkaline waters.

\section{Cladophora as a substrate for epiphytic diatoms}

The heterogeneity of epiphytic diatom communities is a simple and understandable phenomenon, because in the natural environment it is difficult to have homogeneity, uniformity, and no differences in conditions unmodified by humans. In the case of epiphytic diatom communities on macroscopic filamentous algae, there is no doubt that there is a high species richness and heterogeneity in terms of quantitative structure. Each macroscopic green algal species has its own habitat preferences, ecological optima, in which it develops best (Dodds and Gudder 1992; Messyasz et al. 2015a; Schroeder et al. 2016). Mostly, they are ubiquist and cosmopolitan taxa, commonly occurring in fresh, salt, flowing, and standing waters (South and Whittick 1996; Kelly and King 2007; Messyasz et al. 2018a). However, the above research shows that individual species of Cladophora did not occur together; even in similar ecosystems, only each species had a niche suitable only for itself. Cladophora glomerata preferred watercourses, that is, an environment where the water is constantly moving, and it was there that it created mass occurances, sometimes making the rivers take on completely green color. Cladophora globulina is also a widespread species, but in the Wielkopolska region (Poland) it was observed only in an artificial reservoir. Another species, C. fracta, found its niche to grow in an artificial pond. Despite the fact that habitat conditions were similar in all studied ecosystems, and slightly higher nitrate, phosphate, and sulfide values were noted in the rivers, the communities forming macroalgae mats were clearly diversified.

A similar phenomenon can be seen in epiphytes growing on the thalli of filamentous green algae of the genus
Cladophora. Despite similar habitat conditions, diversity in species and quantity composition of diatom communities was observed (Mpawenayo and Mathooko 2005). Diatoms settled more readily on some macroscopic green algae, while on others much slower and in smaller amounts. It cannot be ruled out that this could be due to the cell wall structure of the individual species' thalli, taking into account the amount of cellulose covering the thalli, as well as substances produced by plants that may somehow allelopathically affect diatom communities (Pikosz et al. 2019). The least taxa of diatoms were recorded on Cladophora fracta (O.F. Müller ex Vahl) Kütz., which was located in a small retention reservoir, where pollution from air conditioning is discharged - perhaps this significantly affects the development of periphyton diatoms, causing a certain barrier to their development.

In the case of $C$. glomerata, the largest number of diatom species was observed, which could be due to its rough surface enabling the attachment of individual cells. In addition, the thallus of C. glomerata in all the studied rivers created huge mats that were attached to the ground, so that the epiphytes had the right conditions for development and migration between individual thalli. The vast majority of the composition and biomass of epiphytes were species from the genus Cocconeis, i.e., Cocconeis placentula Ehr. and its varieties, as well as Cocconeis pediculus Ehr. Comte and Cazaubon (2002) also found the largest numbers of diatom cells among Cocconeis pediculus Ehr. and Achnanthidium minutissium (Kütz.) Czarnecki. However, species richness was slightly lower on the thalli of this species of Cladophora where they recorded only 15 diatom taxa. A large proportion of species abundance was observed in the C. glomerata thalli among genera Navicula and Gomphonema, i.e., Gomphonema olivaceum (Horn.) Kützing, Gomphonema parvulum (Kütz.) Kützing, Gomphonema truncatum Ehrenberg, also Navicula cryptocephala Kützing, Navicula menisculus Schumann, Navicula perminuta Grunow in van Heurck, and Navicula recta J. Brun and Héribaud-Joseph.

Another analyzed substrate was C. globulina, whose mats drifted on the surface of the water ecosystems. A large number (ca. 83) of diatom taxa was observed on its thalli surface. In the case of this macroscopic green alga, the biomass and total diatoms on thalli were significantly lower and its composition differed in relation to the species described earlier (C. glomerata). The abundance structure of community lacked a group of epiphytes that would achieve a definite advantage, because only $35 \%$ of the total number were species of the genera Cocconeis and Gomphonema, and about $10 \%$ Cymatopleura. Also, in the case of C. globulina, despite a significantly smaller number of species of the genus Cymatopleura, they achieved a definite advantage in biomass, constituting about $80 \%$ of the total biomass. Cymatopleura elliptica (Bréb.) W. Smith was a definite dominant, followed by Cocconeis placentula, Surirella striatula Turpin, Ulnaria 
ulna (Nitzsch) P. Compère in Jahn et al., and Gomphonema olivaceum. The thalli of $C$. globulina also show surface roughness, which could promote diatom deposits. A characteristic feature of C. globulina in relation to C. glomerata is that it has definitely more delicate threads. The diatom community diversity index was only 0.37 (Messyasz et al. 2012; Schroeder et al. 2016).

Cladophora rivularis was less populated, with only 68 taxa recorded on its thalli. The filaments of this alga are very long and unbranched (Pikosz and Messyasz 2016). On this species thallus surface, significantly fewer diatom cells have been noted than on $C$. glomerata, but definitely more than on other species, whether it be $C$. globulina, C. fracta, or Oedogonium sp. On C. rivularis, the abundance and size of diatoms was much different, with species of the Epithemia genus achieving a decisive advantage on thalli, including Epithemia argus (Ehr.) Kütz., Epithemia cistula (Ehr.) Ralfs, Epithemia sorex Kütz., or Epithemia turgida (Ehr.) Kütz. The genus Cocconeis in this case accounted for only $20 \%$ of the total number, giving way to the genus Epithemia. Among the dominants appeared Epithemia turgida, Cocconeis placentula, Epithemia sorex var. gracilis Hustedt, Epithemia sorex, and Cymatopleura elliptica (Bréb.) W. Smith, which shows that the thalli of C. rivularis is most likely to create a more specific environment than other species of the genus Cladophora.

Cladophora fracta is characterized by a few branches and if they occur, they are usually arranged at an obtuse angle from the main axis (Pliński and Hindák 2012; Škaloud et al. 2018), which means that individual filaments have difficulty entangling. This Cladophora species had the fewest epiphytic diatom taxa, only 44. The abundance and biomass composition differed significantly from that observed in the other macroscopic green algae. In this case, the highest numerousness was reached by species of Gomhonema (40\%), i.e., Gomphonema acuminatum Ehr., Gomphonema angustatum (Kütz.) Rab., Gomphonema olivaceum (Horn.) Kütz., then Navicula (29\%) and Cocconeis $10 \%$. Among the dominants, a completely different composition was also noted: Cymatopleura elliptica (Bréb.) W. Smith, Navicula perminuta Grun. in van Heurck, Cocconeis placentula Ehr., Gomphonema minutum (Ag.) C. Ag., Gomphonema parvulum (Kütz.) Kütz. On the thalli of Cladophora fracta, there was a clear heterogeneity of the diatom community at abundance level; however, Shannon-Weaver biodiversity remained at a low level of about 0.4 (Messyasz et al. 2012; Schroeder et al. 2016).

Undoubtedly, thalli of Cladophora are a good substrate for the development of epiphytic species and are eagerly inhabited by diatoms. Numerous studies confirm that the diatom distribution is strongly correlated with the substrate architecture of colonized macroalgae (Johnson et al. 1996; Comte and Cazaubon 2002; Messyasz and Kuczyńska-Kippen 2006; Stewart and Lowe 2008) and habitat conditions (Cambra and Aboal 1992; Pihl et al. 1999; Škaloud et al. 2018).

\section{Harvesting and culture conditions}

Cladophora species grow on submerged rocks and stones or move freely in water (Mihranyan 2011; Munir et al. 2019). These algae proliferate usually in a shallow water. Mats formed by Cladophora, which float on the water surface, can be collected manually or using boats equipped with a special rake, a cable, or a strip (Messyasz et al. 2015b; Munir et al. 2019). For the habitat characterization, the basic physio-chemical parameters of the water (temperature, conduction, concentration of oxygen, and $\mathrm{Cl}^{-}$as well as the $\mathrm{pH}$ level) at the same sites as macroalgae thalli should be measured using, e.g., the YSI Professional Plus handheld multiparameter meter. Considering that the algal analyses in the laboratory require the right amount of material, it is recommended to gather about $500 \mathrm{~g}$ of thalli. It is advisable to place thalli in a plastic container and transport and store after collection in a refidgerator $\left(\right.$ at $4{ }^{\circ} \mathrm{C}$ ) at the laboratory. The collected algae should be washed and cleaned of solid impurities prior to drying (Munir et al. 2019). Depending on further laboratory work, the purified thalli are best divided into parts and used for microscopic analysis and morphometric measurements of thalli and cells, to prepare herbarium specimens or to analyze the chemical composition (Messyasz et al. 2015a; Piotrowicz et al. 2019). To preserve fresh material, part of the collected sample (at least $400 \mathrm{~g}$ ) can be placed in an 10-L aquarium with water filtered from habitat, or the MWC medium (Guillard and Lorenzen 1972) or the Wang medium and then placed in phytotrons (at $250 \mu \mathrm{mol}$ photons $\mathrm{m}^{-2} \mathrm{~s}^{-1}$, light:dark period $12: 12$, temperature $21^{\circ} \mathrm{C}$ ) to conduct macro-cultures in open or closed system (Andersen 2005).

Each planned experiment should be preceded by a process of acclimatization, in order to mitigate the initial stress caused by transportation, change of lighting, and thermal conditions, as well as to obtain biogenic stabilization in the thalli. Cultivation of algal biomass are conducted using only those specimens which display no mechanical damage, necrosis, and chlorosis. Open cultures are mainly related to algae culture on a large scale or in cases where experimental sets occupy a large surface. Many researchers recommend that to examine the ecological mutual relations, a construction of small containers for breeding algae with other organisms (e.g., shrimp) is needed (RobertsonAndersson et al. 2008; Cruz-Suárez et al. 2010). The open culture are often equipped with pipes supplying water enriched with nutrients and providing water circulation, the heater modeling the temperature of water, devices for simulating the movements of water, or artificial light source (Lüning et al. 2008), and thalli of algae instead of freely floating on the water are deposited on the special nets or other similar media (Msuya and Neori 2008).

In contrast, algal cultures in phytotron chambers can be freely modified such environmental factors as: air temperature, which is set by the heating and cooling systems, maintaining the temperature regardless of the 
surroundings, circulation and humidity, intensity and color of light, and also day lengths. The composition of medium for the cultivation of macroscopic algae may be adapted to particular species, so as to simulate their most preferred habitat conditions. The components of the culture medium, which can then be elective modeled are nitrogen, phosphorus, pH buffers, salinity (minimum $30 \mathrm{ppt}$ ), and optionally trace metals and vitamins defined by the medium recipe. Messyasz et al. (2015c) noted that modifying the culture medium through compounds (ascorbic acid, biotin, glucose, sucrose) had only short-term effects on the composition of algal biomass. On the basis of experimental results and on field observations, it was confirmed that the concentration of nutrients for the successful growth of macroalgae including Cladophora was appropriate in the Wang culture medium or the Benecke medium (with some modifications) (Andersen 2005; Pikosz et al. 2019). The relatively high content of $\mathrm{N}$ and $\mathrm{P}$ present in these media is similar to that existing in a eutrophic reservoir habitat (Schiewer 2008). Species of the genus Cladophora differ substantially in terms of levels of certain nutrient preference; it is therefore necessary to make the proper identification of the species which was collected for testing in the culture.

\section{Chemical composition}

Macroalgae are known to be a rich source of biologically active compounds. The production of a great variety of secondary metabolites that cannot be found in other organisms results out of necessity to quickly adapt to new environmental conditions. These compounds protect the algal cells against stressful conditions, such as ultraviolet radiation, sudden temperature changes, fluctuations in nutrient concentration, and salinity level (Elenkov et al. 1996a; Rani 2007; Laungsuwon and Chulalaksananukul 2014). Cladophora species have the ability to survive in a highly saline environment (up to $100 \%$ o of salinity) what makes them ecologically important (Elenkov et al. 1996b). The general chemical composition of Cladophora species is presented in Table 3. This alga contains a high amount of carbohydrates, minerals, and proteins and is characterized by high moisture-typically around 90\% (Srimaroeng et al. 2015).

The composition of Cladophora largely depends on the environment from which this biomass is collected or the algae cultivation conditions, and season, as well as algae species and many other factors. As it was shown in the work of Khuantrairong and Traichaiyaporn (2011), the biomass of freshwater alga Cladophora sp. cultured in the medium with the addition of $10 \%$ of canteen wastewater and di-potassium hydrogen orthophosphate contained more protein, carotenoids
( $\beta$-carotene, lutein, and zeaxanthin), and vitamin $\mathrm{A}$, when the concentration of phosphorus increased in the medium when compared to the biomass from the control group. The supplementation of phosphorus to the medium can enhance the production, as well as the nutritional value of this alga. Reduced phosphate availability in water can markedly decline the amount of the Cladophora biomass. Other limiting factors are the concentration of nitrogen, trace elements, and vitamins (Parker and Maberly 2000).

The presence of biologically active compounds in seaweed products can differ also due to the chosen extraction method, organic solvents used for their extraction, and differences in assay methods (Yuvaraj et al. 2011; Messyasz et al. 2018b). For example, Fabrowska et al. (2018) showed that for the extraction of phenolic compounds and pigments (chlorophylls and carotenoids) from freshwater $C$. glomerata, microwaveassisted extraction (MAE) and superficial fluid extraction (SFE) with $\mathrm{CO}_{2}$ methods were more effective, respectively. It is also important to select an appropriate solvent in order to achieve high extraction yield and isolation of a given compound from algae (Yuvaraj et al. 2011; Yuvarani et al. 2017; Messyasz et al. 2018b). For example, Yarnpakdee et al. (2019) showed that in the case of water extraction of C. glomerata, the extraction yield was $28.0 \%$, whereas for the extraction with ethanol it ranged from 2.98 to $15.5 \%$, depending on the concentration of ethanol used for this process.

\section{Carbohydrates}

The content of carbohydrates in marine and freshwater Cladophora species is comparable and about 60\% (Table 3). The Cladophora cell wall is composed mainly of cellulose that is usually highly crystalline (Ek et al. 1998; Mihranyan 2011; Camacho et al. 2013). Its content can be as high as $45 \%$ by weight (Mihranyan 2011). Cladophora glomerata is also an interesting source of polysaccharide called ulvan, whose main component is 3 -sulfated rhamnoglucuronan. Its amount in the Cladophora cells increases with increasing size of the thalli. Mono- and oligo-saccharides produced from ulvan can potentially be applied in pharmaceutical, cosmetic, and food industry (Pankiewicz et al. 2016).

\section{Lipids}

The lipid content in the algal biomass is generally low-less than $5 \%$ of dry weight (Table 3). Kamenarska et al. (2004) examined the lipid composition of brackishwater $C$. rivularis, which included four main lipid classes, such as triacylglycerols-33.3\% by weight from the total lipids, monogalactosyldiacylglycerols- $56.4 \%$ by weight, digalactosyldiacylglycerols $-2.5 \%$ by weight and phospholipids $-7.8 \%$ by weight. An important component of algae are fatty acids, especially polyunsaturated fatty acids, which 
Table 3 Chemical composition of Cladophora species

\begin{tabular}{|c|c|c|c|c|c|}
\hline \multirow{2}{*}{$\begin{array}{l}\text { Substance } \\
(\%)\end{array}$} & \multicolumn{5}{|l|}{ Species } \\
\hline & $\begin{array}{l}\text { C. glomerata (F; } \\
\text { Oporzyn Lake, Poland) } \\
\text { (Messyasz et al. 2015b) }\end{array}$ & $\begin{array}{l}\text { Cladophora sp. (F; } \\
\text { cultivated) } \\
\text { (Khuantrairong and } \\
\text { Traichaiyaporn 2011) }\end{array}$ & $\begin{array}{l}\text { C. glomerata (F; } \\
\text { Acıöl Lake, } \\
\text { Turkey) } \\
\text { (Akköz et al. 2011) }\end{array}$ & $\begin{array}{l}\text { C. glomerata (F; } \\
\text { Lake, Poland) } \\
\text { (Michalak et al. 2018b) }\end{array}$ & $\begin{array}{l}\text { C. socialis, C. prolifera, } \\
\text { C. crupila (M; Vietnam) } \\
\text { (Vo Thanh Trung et al. 2013) }\end{array}$ \\
\hline Moisture & 95.56 & $89.02 \pm 1.91$ & n.a. & n.a. & $88.5,86.6,86.9$ \\
\hline Ash & 39.25 & $15.29 \pm 1.11$ & $2.44 \pm 0.07$ & 22.6 & $7.71,7.76,8.40$ \\
\hline Total protein & 14.45 & $10.71 \pm 1.14$ & $14.13 \pm 1.13$ & 22.5 & $20.9,15.0,17.4$ \\
\hline Crude fiber & 15.60 & $23.05 \pm 2.63$ & n.a. & 19.6 & n.a. \\
\hline Crude fat & 0.78 & $2.04 \pm 0.78$ & $2.48 \pm 0.12$ & 0.4 & $1.52,2.06,2.37$ \\
\hline Carbohydrate & n.a. & $60.98 \pm 1.57$ & n.a. & 4.1 (starch) & $58.4,61.7,58.8$ \\
\hline
\end{tabular}

$F$ freshwater, $M$ marine, n.a. data not available

are crucial for human and animal health. In many research papers, it was shown that macroalgae (both marine and freshwater) are rich in saturated and unsaturated fatty acids (Table 4). For example, C. vagabunda contains $39.6 \pm 2.1 \%$ of saturated and $29.3 \pm 3.8 \%$ of total unsaturated fatty acids (Horincar et al. 2014), and C. glomerata $32.7 \%$ of saturated and $29.8 \%$ of unsaturated fatty acids (Messyasz et al. 2015b). Messyasz et al. (2018b) showed that there were differences in the content of fatty acids (\%) in freshwater $C$. glomerata depending on the extraction technique and solvent used. For the Soxhlet extraction, this content was as follows: hexane $28.8 \pm$ $0.63 \%$, acetone $34.0 \pm 1.02 \%$, ethanol $21.2 \pm 0.71 \%$ and 36.4 $\pm 1.32 \%$ for supercritical fluid extraction with $\mathrm{CO}_{2}$.

The content of lipids in Cladophora species can vary depending on salinity. Higher salinity (lake 50\%o, saltpan 200\%o) lowered total lipid content in C. vagabunda (Elenkov et al. 1996b). According to the authors, the changes in algal lipid composition resulted probably from the adaptation to salt stress. Phospholipids were not affected by the salt stress. At lower salinity, there was a high content of triacylglycerols. Cladophora vagabunda from the saltpan had increased content of saturated fatty acids, which lower the cell membrane permeability which can be probably also an adaptive mechanism (Elenkov et al. 1996b), although in the work of Elenkov et al. (1996a), it was shown that there were no statistically significant differences between marine (C. rivularis, $C$. laetevirens and C. sericea) and freshwater species (C. glomerata), neither in the lipid composition nor in the fatty acid profile. The authors demonstrated that glicolipids, with monogalactosyl and diacylglycerols as the main components, were the dominant lipid class in Cladophora species. Palmitic and linolenic fatty acids occurred in the largest quantities.

\section{Protein and amino acids}

Cladophora species can also serve as a source of protein. Protein content ranges from $\sim 10$ to $\sim 25 \%$ and is comparable to feed materials (Heiba et al. 1997). Cladophora species have also interesting composition of amino acids, which can be influenced by the environmental conditions (Messyasz et al. 2015b; Marycz et al. 2017; Pikosz et al. 2019). The main

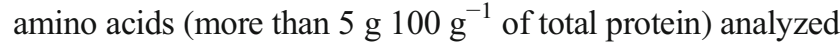
in Cladophora species (C. glomerata and C. fracta) were aspartic and glutamic acid, leucine, glycine, alanine, arginine, and valine (Table 5). Rani (2007) showed that with the increase of salinity, the content of free amino acids - arginine, aspartate, glutamate, glycine, histidine, and lysine-in C. vagabunda increased, but valine slightly decreased. Decrease of salinity caused a drop in arginine, aspartate, glycine, histidine, threonine, and valine content, but a steep increase in glutamate and lysine. It is suggested that such a response to salinity change in the environment can result from the role of amino acids as osmoticants.

\section{Pigments}

Cladophora species are a rich source of pigments such as chlorophylls ( $a$ and $b$ ) and carotenoids ( $\beta$-carotene, lutein, and zeaxanthin). Khuantrairong and Traichaiyaporn (2011) showed that cultivated Cladophora sp. contained carotenoids, such as $\beta$-carotene $20.0 \pm 14.0 \mu \mathrm{g} \mathrm{g}^{-1}$, lutein $173 \pm 48 \mu \mathrm{g} \mathrm{g}^{-1}$, and zeaxanthin $24.6 \pm 12.5 \mu \mathrm{g} \mathrm{g}^{-1}$. Messyasz et al. (2018b) showed that the content of chlorophyll $a$ in marine $C$. glomerata was $0.30 \pm$ $0.01 \mathrm{mg} \mathrm{g}^{-1}$ and carotenoids $0.08 \pm 0.01 \mathrm{mg} \mathrm{g}^{-1}$ in extract of the dry algal biomass. Pikosz et al. (2019) compared the content of pigments in two freshwater species- $C$. glomerata and $C$. fracta. The first alga contained pigments in higher amounts (chlorophylls: chlorophyll $a 8.45 \pm 0.18 \mu \mathrm{g} \mathrm{mL} L^{-1}$, chlorophyll $b$ $6.36 \pm 0.11 \mu \mathrm{g} \mathrm{mL}^{-1}$, and carotenoids $2.32 \pm 0.03 \mu \mathrm{g} \mathrm{mL}^{-1}$ ) than C. fracta where these values were as follows: $3.13 \pm$ $0.12 \mu \mathrm{g} \mathrm{mL}^{-1}, 2.95 \pm 0.07 \mu \mathrm{g} \mathrm{mL}^{-1}, 0.72 \pm 0.05 \mu \mathrm{g} \mathrm{mL}^{-1}$, respectively. Fabrowska et al. (2018) indicated that in the case of pigments in thalli of freshwater C. glomerata (chlorophylls and 
Table 4 The content of fatty acids (\% weight in dry matter of the extract) in Cladophora species

\begin{tabular}{|c|c|c|c|c|c|c|c|c|}
\hline \multirow{3}{*}{$\begin{array}{l}\text { Polyunsaturated/ } \\
\text { saturated fatty } \\
\text { acid }\end{array}$} & \multicolumn{8}{|l|}{ Species } \\
\hline & \multicolumn{3}{|c|}{$\begin{array}{l}\text { C. glomerata (F; Oporzyn Lake, } \\
\text { Poland) } \\
\text { (Messyasz et al. 2015b) }\end{array}$} & \multirow{2}{*}{$\begin{array}{l}\text { C. vagabunda } \\
\text { (M; Black Sea, } \\
\text { Romania) } \\
\text { (Horincar et al. } \\
\text { 2014) } \\
\text { Sonication: } \\
\text { hexane }\end{array}$} & \multirow{2}{*}{$\begin{array}{l}\text { C. fracta (F; Tokat } \\
\text { Gaziosmanpasa } \\
\text { University, Turkey) } \\
\text { (Karan and Erenler } \\
\text { 2018) } \\
\text { Extraction: hexane, } \\
\text { re-extraction: methanol }\end{array}$} & \multirow{2}{*}{$\begin{array}{l}\text { C. glomerata } \\
\text { (F; Oporzyn } \\
\text { Lake, Poland) } \\
\text { (Messyasz } \\
\text { et al. 2018b) } \\
\text { Soxhlet: } \\
\text { ethanol }\end{array}$} & \multirow{2}{*}{$\begin{array}{l}\text { C. rupestris (M; } \\
\text { Mar Piccolo of } \\
\text { Taranto, Ionian } \\
\text { Sea) } \\
\text { (Stabili et al. } \\
\text { 2014) } \\
\text { Soxhlet: } \\
\text { chloroform/ } \\
\text { methanol }\end{array}$} & \multirow{2}{*}{$\begin{array}{l}\text { C. glomerata } \\
\text { (M; Quatar) } \\
\text { (Heiba et al. } \\
\text { 1997) } \\
\text { Extraction: } \\
\text { chloroform/ } \\
\text { methanol }\end{array}$} \\
\hline & $\begin{array}{l}\text { Soxhlet: } \\
\text { ethanol }\end{array}$ & $\begin{array}{l}\text { Soxhlet: } \\
\text { acetone }\end{array}$ & $\begin{array}{l}\text { Supercritical } \\
\text { fluid } \\
\text { extraction- }-\mathrm{CO}_{2}\end{array}$ & & & & & \\
\hline C9:0 & 1.9 & 1.6 & 2.0 & n.a. & n.a. & $3.0 \pm 0.3$ & n.a. & n.a. \\
\hline $\mathrm{C} 10: 0$ & n.d. & n.d. & n.d. & n.a. & n.a. & $<$ LLD & $0.02 \pm 0.01$ & n.a. \\
\hline C11:0 & n.d. & n.d. & n.d. & n.a. & n.a. & $<$ LLD & n.a. & n.a. \\
\hline $\mathrm{C} 12: 0$ & 0.1 & 0.2 & n.d. & n.a. & 0.42 & $<$ LLD & $1.18 \pm 0.16$ & n.a. \\
\hline C14:0 & 2.7 & 3.0 & 12.5 & $9.0 \pm 0.08$ & 4.46 & $2.7 \pm 0.4$ & $16.4 \pm 1.3$ & 5.8 \\
\hline $\mathrm{C} 15: 0$ & n.a. & n.a. & n.a. & $0.5 \pm 0.5$ & 9.29 & n.a. & n.a. & n.a. \\
\hline C16:0 & 5.9 & 7.1 & 17.4 & $24.6 \pm 2.0$ & 15.6 & $8.2 \pm 1.2$ & $28.9 \pm 1.8$ & 19.7 \\
\hline C18:0 & 0.4 & 0.8 & 0.6 & $5.4 \pm 0.8$ & 2.21 & $0.1 \pm 0.01$ & $0.83 \pm 0.15$ & 8.8 \\
\hline C20:0 & n.d. & n.d. & n.d. & $0.1 \pm 0.03$ & n.a. & $<$ LLD & $0.32 \pm 0.11$ & 0.3 \\
\hline $\mathrm{C} 22: 0$ & n.d. & n.d. & 0.2 & n.a. & n.a. & $<$ LLD & n.a. & 0.5 \\
\hline C16:1 (n-7) & 1.9 & 2.8 & 4.9 & $0.3 \pm 0.05$ & n.a. & $2.0 \pm 0.3$ & n.a. & $16: 1-3.5$ \\
\hline C16:1 (n-9) & n.a. & n.a. & n.a. & $0.7 \pm 0.1$ & n.a. & n.a. & n.a. & \\
\hline C18:1 (n-9) & 1.0 & 1.4 & 9.3 & $11.3 \pm 1.3$ & 46.0 & $1.0 \pm 0.09$ & $4.46 \pm 0.79$ & 19.3 \\
\hline $\begin{array}{l}\text { C18:2 (n-9) } \\
\text { C18:2 (n-6) }\end{array}$ & $\begin{array}{l}\text { n.a. } \\
1.9\end{array}$ & $\begin{array}{l}\text { n.a. } \\
3.0\end{array}$ & $\begin{array}{l}\text { n.a. } \\
6.5\end{array}$ & $\begin{array}{l}2.4 \pm 0.3 \\
\text { n.a. }\end{array}$ & $\begin{array}{l}\text { n.a. } \\
7.53\end{array}$ & $\begin{array}{l}\text { n.a. } \\
1.5 \pm 0.2\end{array}$ & $\begin{array}{l}\text { n.a. } \\
1.89 \pm 0.65\end{array}$ & $18: 2-15.1$ \\
\hline $\begin{array}{l}\text { C18:3 (n-3) } \\
\text { C18:3 (n-6) }\end{array}$ & $\begin{array}{l}1.7 \\
\text { n.d. }\end{array}$ & $\begin{array}{l}2.2 \\
\text { n.d. }\end{array}$ & $\begin{array}{l}5.2 \\
\text { n.d. }\end{array}$ & $\begin{array}{l}\text { n.a. } \\
\text { n.a. }\end{array}$ & $\begin{array}{l}\text { n.a. } \\
10.7\end{array}$ & $\begin{array}{l}4.0 \pm 0.3 \\
<\text { LLD }\end{array}$ & $\begin{array}{l}12.4 \pm 0.9 \\
0.81 \pm 0.07\end{array}$ & $18.3-1.0$ \\
\hline C18:4 (n-3) & 1.5 & 3.0 & 3.1 & n.a. & n.a. & $1.6 \pm 0.1$ & n.a. & n.a. \\
\hline $\mathrm{C} 20: 2(\mathrm{n}-6)$ & n.a. & n.a. & n.a. & $0.4 \pm 0.02$ & n.a. & n.a. & $2.11 \pm 0.21$ & 6.5 \\
\hline $\mathrm{C} 20: 3(\mathrm{n}-6)$ & n.a. & n.a. & n.a. & $0.8 \pm 0.1$ & n.a. & n.a. & $0.88 \pm 0.08$ & 1.5 \\
\hline $\mathrm{C} 20: 4(\mathrm{n}-6)$ & n.d. & n.d. & n.d. & $23.0 \pm 3.0$ & n.a. & $<$ LLD & $0.86 \pm 0.13$ & n.a. \\
\hline $\mathrm{C} 20: 5(\mathrm{n}-3)$ & n.d. & n.d. & n.d. & n.a. & 8.37 & $<$ LLD & $1.32 \pm 0.31$ & n.a. \\
\hline $\mathrm{C} 20: 5(\mathrm{n}-6)$ & n.a. & n.a. & n.a. & $2.7 \pm 0.7$ & n.a. & n.a. & n.a. & n.a. \\
\hline $\mathrm{C} 22: 1$ (n-9) & n.d. & n.d. & n.d. & n.a. & 0.22 & $<$ LLD & n.a. & n.a. \\
\hline $\mathrm{C} 22: 6(\mathrm{n}-3)$ & n.d. & n.d. & n.d. & n.a. & n.a. & $<$ LLD & $2.21 \pm 0.52$ & 12.5 \\
\hline
\end{tabular}

n.a. data not available, $n . d$. not detected, $L L D$ below lower limit of detection

carotenoids), there are seasonal differences. Additionally, the content of these compounds is influenced by C. glomerata habitat.

\section{Minerals}

Generally, macroalgae are considered to have a high ash content, micro- and macroelements, essential minerals, and trace elements that are required by all living organisms. As can be seen from Table 3, ash content in Cladophora species varied from $2.44 \%$ in freshwater C. glomerata (Akköz et al. 2011) to $39 \%$ also in in algae of the same species (Messyasz et al. 2015a). The mineral composition of Cladophora species is presented in Table 6.

\section{Vitamins}

Important from the nutritional and medicinal point of view are also vitamins. Cladophora species are known to contain a wide range of vitamins. Khuantrairong and Traichaiyaporn (2011) showed that the cultivated Cladophora sp. contained vitamins $\mathrm{A}\left(0.33 \pm 0.23 \mathrm{mg}(100 \mathrm{~g})^{-1}\right), \mathrm{B}_{1}(0.05 \pm 0.01 \mathrm{mg}$ $\left.(100 \mathrm{~g})^{-1}\right), \mathrm{B}_{2}\left(0.05 \pm 0.00 \mathrm{mg}(100 \mathrm{~g})^{-1}\right), \mathrm{C}(1.89 \pm 0.10 \mathrm{mg}$ $\left.(100 \mathrm{~g})^{-1}\right)$, and $\mathrm{E}\left(5.97 \pm 0.13 \mathrm{mg}(100 \mathrm{~g})^{-1}\right)$. Cladophora 
Table 5 The content of amino acids ( $\mathrm{g}(100 \mathrm{~g})^{-1}$ of total protein) in Cladophora species

\begin{tabular}{llll}
\hline Amino acid & Species & & \\
\cline { 2 - 4 } & $\begin{array}{l}\text { C. glomerata } \text { (F; Oporzyn } \\
\text { Lake, Poland) } \\
\text { (Messyasz et al. 2015b) }\end{array}$ & $\begin{array}{l}\text { C. glomerata } \text { (F; Lake, } \\
\text { Tomaszówek, Poland) } \\
\text { (Marycz et al. 2017) }\end{array}$ & $\begin{array}{l}\text { C. fracta } \text { (F; Malta Reservoir, } \\
\text { Poznan, Poland) } \\
\text { (Pikosz et al. 2019) }\end{array}$ \\
\hline Aspartic acid & 10.52 & $1.50 \pm 0.16$ & $10.53 \pm 0.00$ \\
Threonine & 4.57 & $0.60 \pm 0.03$ & $4.53 \pm 0.00$ \\
Serine & 4.35 & $0.73 \pm 0.04$ & $4.50 \pm 0.00$ \\
Glutamic acid & 12.46 & $1.82 \pm 0.07$ & $12.69 \pm 0.01$ \\
Proline & 4.51 & $0.81 \pm 0.03$ & $4.50 \pm 0.00$ \\
Cysteine & 1.51 & $0.092 \pm 0.008$ & $1.51 \pm 0.00$ \\
Glycine & 5.13 & $1.31 \pm 0.07$ & $5.17 \pm 0.00$ \\
Alanine & 5.46 & $1.52 \pm 0.07$ & $5.46 \pm 0.00$ \\
Valine & 5.40 & $1.16 \pm 0.06$ & $5.51 \pm 0.00$ \\
Methionine & 0.82 & $0.23 \pm 0.01$ & $0.79 \pm 0.00$ \\
Isoleucine & 3.36 & $0.83 \pm 0.04$ & $3.40 \pm 0.00$ \\
Leucine & 6.58 & $1.50 \pm 0.04$ & $9.65 \pm 0.00$ \\
Tyrosine & 2.83 & $0.74 \pm 0.03$ & $2.87 \pm 0.00$ \\
Phenylalanine & 4.32 & $0.92 \pm 0.07$ & $4.41 \pm 0.00$ \\
Histidine & 2.17 & $0.090 \pm 0.010$ & $2.21 \pm 0.00$ \\
Lysine & 4.78 & $0.56 \pm 0.05$ & $5.17 \pm 0.00$ \\
Arginine & 7.23 & $0.92 \pm 0.02$ & $7.41 \pm 0.00$ \\
& & &
\end{tabular}

glomerata from Polish pond contained vitamin C $-21.7 \mathrm{mg}$ $(100 \mathrm{~g})^{-1}$ of dry mass, and vitamin E-2.5 mg $(100 \mathrm{~g})^{-1}$ (Marycz et al. 2017).

\section{Utilization}

Cladophora species, both marine and freshwater, are ecologically and economically important macroalgae that provide essential ecosystem services and biomass for soil additives, fertilizers, biostimulants of plant growth, animal feeds, foods, phycocolloids, neutraceuticals, pharmaceuticals, and cosmetics, as well as for wastewater treatment, renewable biofuel production, etc. (Mihranyan 2011; Zulkifly et al. 2013). Cladophora species can be also used in construction materials due to the content of cellulose which can be used as a reinforcement fibers (e.g., in polyurethane foams) (Mihranyan 2011).

Due to high content of proteins, Cladophora species are recommended as a valuable supplement in human food, as well as in animal feed (Messyasz et al. 2015a). As a biomass characterized by low content of calories and high content of minerals, vitamins and fiber is used in the food industry (Akköz et al. 2011). Macroalgal pigments have many applications such as natural colorants applied as food pigments (in dairy products, beverages, etc.), as feed additives (e.g., aquaculture), and as components of cosmetics and pharmaceuticals. It is worth mentioning that Cladophora as an edible macroalga is consumed as a part of the diet in many parts of the world (Amornlerdpison et al. 2011). For example, in northern Thailand, edible Cladophora, known as "Kai," is an economically and ecologically important green alga (Pereira 2016). Cladophora species possess also very good sorption properties, therefore can be used in the wastewater remediation. The most interesting and promising applications of the biomass of Cladophora and products obtained from it are presented in this review.

\section{Pharmaceutical and nutraceutical applications}

Due to their chemical composition, Cladophora species constitute potential raw material for pharmaceutical, nutritional, and cosmetic applications. Algal biologically active compounds demonstrate many activities such as antioxidant, anticancer, antineoplastic, antidiabetic, anti-hypertensive, antimicrobial, antiviral, anti-parasitic, and cytotoxicity activity (Soltani et al. 2011; Horincar et al. 2014; Zbakh et al. 2014; Srimaroeng et al. 2015; Lezcano et al. 2018; Munir et al. 2019). In the review paper of Munir et al. (2019), the main activities of algae (antibacterial, anti-mycobacterial, antifungal, anti-parasitic, antioxidant, anti-coagulant, antidiabetic, anti-inflammatory/antioedema, anticancer, immunomodulatory, anti-ulcer, hypotensive and analgesic activity) are described in detail. 
Table 6 Multielemental composition of Cladophora species

\begin{tabular}{|c|c|c|c|c|}
\hline \multirow[t]{2}{*}{ Element } & \multicolumn{4}{|l|}{ Species } \\
\hline & $\begin{array}{l}\text { C. glomerata (F; Oporzyn } \\
\text { Lake, Poland) } \\
\text { (Messyasz et al. 2015b) }\end{array}$ & $\begin{array}{l}\text { Cladophora sp. (F; cultivated, } \\
\mathrm{mg} \mathrm{kg}^{-1} \text { of dry biomass) } \\
\text { (Khuantrairong and } \\
\text { Traichaiyaporn 2011) }\end{array}$ & $\begin{array}{l}\text { C. glomerata (F; Acıgöl Lake, } \\
\text { Turkey, mg kg }{ }^{-1} \text { of dry biomass) } \\
\text { (Akköz et al. 2011) }\end{array}$ & $\begin{array}{l}\text { C. glomerata (F; Lake, Tomaszówek, } \\
\text { Poland, } \mathrm{mg} \mathrm{kg}^{-1} \text { of dry biomass) } \\
\text { (Michalak et al. 2018b) }\end{array}$ \\
\hline $\mathrm{Ca}$ & $146.2 \pm 3.4 \mathrm{~g} \mathrm{~g}^{-1}$ & $66,310 \pm 2090$ & $35,632 \pm 137$ & $56,786 \pm 11,357$ \\
\hline $\mathrm{Mg}$ & $3.63 \pm 0.02 \mathrm{~g} \mathrm{~g}^{-1}$ & $2420 \pm 187$ & $10,268 \pm 142$ & $2951 \pm 590$ \\
\hline $\mathrm{Na}$ & $0.47 \pm 0.02 \mathrm{~g} \mathrm{~g}^{-1}$ & n.a. & $8554 \pm 143$ & $723 \pm 108$ \\
\hline $\mathrm{K}$ & n.a. & $26,580 \pm 2000$ & $52,048 \pm 198$ & $25,122 \pm 5024$ \\
\hline $\mathrm{P}$ & n.a. & $692 \pm 12$ & $2347 \pm 103$ & $2269 \pm 454$ \\
\hline $\mathrm{Fe}$ & $0.19 \pm 0.01 \mathrm{~g} \mathrm{~g}^{-1}$ & $299 \pm 19$ & $7847 \pm 67$ & $1650 \pm 330$ \\
\hline $\mathrm{Zn}$ & $0.03 \pm 0.01 \mathrm{~g} \mathrm{~g}^{-1}$ & $19.1 \pm 0.4$ & $10.51 \pm 1.09$ & $15.96 \pm 2.39$ \\
\hline $\mathrm{Cu}$ & $0.05 \pm 0.01 \mathrm{~g} \mathrm{~g}^{-1}$ & n.a. & $7.15 \pm 0.97$ & $4.90 \pm 0.74$ \\
\hline As & $0.53 \pm 0.05 \mu \mathrm{g} \mathrm{g}^{-1}$ & n.a. & n.a. & n.a. \\
\hline $\mathrm{Cd}$ & $0.07 \pm 0.01 \mu \mathrm{g} \mathrm{g}^{-1}$ & n.a. & $1.19 \pm 0.06$ & $0.10 \pm 0.01$ \\
\hline $\mathrm{Ni}$ & $0.15 \pm 0.03 \mu \mathrm{g} \mathrm{g}^{-1}$ & n.a. & $8.09 \pm 0.78$ & $2.14 \pm 0.32$ \\
\hline $\mathrm{Pb}$ & $0.80 \pm 0.09 \mu \mathrm{g} \mathrm{g}^{-1}$ & n.a. & $5.03 \pm 0.36$ & $2.76 \pm 0.36$ \\
\hline $\mathrm{Cr}$ & $0.01 \pm 0.00 \mu \mathrm{g} \mathrm{g}^{-1}$ & n.a. & $3.34 \pm 0.19$ & $6.16 \pm 0.92$ \\
\hline $\mathrm{Mn}$ & $0.09 \pm 0.03 \mu \mathrm{g} \mathrm{g}^{-1}$ & n.a. & $2977 \pm 142$ & $588 \pm 88$ \\
\hline Co & $0.01 \pm 0.00 \mu \mathrm{g} \mathrm{g}^{-1}$ & n.a. & $12.56 \pm 1.19$ & n.a. \\
\hline
\end{tabular}

n.a. data not available

One of the most important activities of Cladophora species in terms of pharmaceutical, nutraceutical, and cosmetic applications is substantial antioxidant activity. In Table $7 \mathrm{a}$, the examples of the antioxidant activity of Cladophora species are presented. Macroalgae contain many antioxidative molecules such as polyphenols, vitamins - ascorbic acid - tocopherols, pigments - carotenoids, chlorophylls - and polysaccharides. Among them, the most important are polyphenols. There is a strong correlation between the antioxidant activity of the sample and the content of phenolic compounds in Cladophora (Messyasz et al. 2018a). But, as it was shown by Fabrowska et al. (2018), the secretion of phenolic compounds by freshwater $C$. glomerata decreased with aging the algae population. Additionally, there are seasonal differences in the content of phenols in thalli of freshwater C. glomerata and the content of these compounds is influenced by C. glomerata habitat (Fabrowska et al. 2018). Antioxidant activity of Cladophora species can be higher if the biomass occurs in adverse environmental conditions. Zubia et al. (2007) found that tropical macroalgae, including Cladophora, developed an effective antioxidant defense system which may reflect the adaptation of algae to high solar radiation.

Main classes of phytochemicals in Cladophora spp. include the following: lipid (glycolipids, monogalactosyldiacyl glycerol, digalactosyldiacyl glycerols), fatty acid (palmitic, linolenic, hexadecatetraenoic, oleic acids, palmitoleic, myristic, hexadecanoic acid, 9-methyl-10-hexadecenoic acid), volatile fraction (palmitic, myristic acids, hexahydrofarnesylacetone, phytol, benzyl alcohol, dihydroactinidiolide, myrtenal, nonan-2-one), terpense, alcohol (butane-2,3-diol), phenols (2-methylphenol), aldehyde (deca-2,4-dienal, hexanal, oct-2-enal), glycoside $(\beta$ sitosteryl-galactoside) (Munir et al. 2019). Terpenoids and sterols in $C$. vagabunda were studied by Elenkov et al. (1995) and in C. rivularis by Kamenarska et al. (2004). In the work of Amornlerdpison et al. (2011), it was found that water extract of freshwater $C$. glomerata contained phenolic compounds, such as phynyl ester and methoxyl phenyl.

Antioxidant activity of Cladophora extracts is examined mainly in terms of total phenolic and flavonoid content, DPPH and ABTS radical scavenging activity, iron chelating activity, and nitric oxide-scavenging activity (Table 7a). As can be seen from this table, more often freshwater species are examined than marine. Detailed identification of the antioxidant compounds in Cladophora extracts will allow their evaluation in food production, cosmetic industry, and medicine. Cladophora species extracts could be a promising source for drug development (Karan and Erenler 2018), not only because of the mentioned properties, but also due to characteristics of the alga itself. Cellulose from Cladophora due to large surface area and inertness can be used as a drug carrier (also for liquid drugs) (Mihranyan 2011). Antioxidant properties of Cladophora extracts can be also used in food industry. 
Yarnpakdee et al. (2019) examined the effect of ethanolic extracts on the prevention against lipid oxidation of refrigerated tuna slice. It was shown that the extract obtained from freshwater macroalga (C. glomerata) with $60 \%$ ethanol had very good antioxidant activity due to the content of hydroquinin, quercetin, and isoquercetin as major components that could retard lipid oxidation in tuna fish slices. This extract applied at a dose $400 \mathrm{mg} \mathrm{kg}^{-1}$ prevented lipid oxidation during 10 days of refrigerated storage. In the future, it is necessary to evaluate activities of Cladophora extracts in the real systems (e.g., food preservation activity). Algal extract can be used as natural antioxidant to prevent lipid oxidation in food products during their storage or transportation. Lipidic extracts from marine $C$. rupestris, rich in n-3 fatty acid, can be also used in a human diet or in the production of nutraceuticals and replacements for fish oil (Stabili et al. 2014).

Extracts produced from Cladophora species demonstrate also antimicrobial properties (Table 7b). Antimicrobial activity of Cladophora extract can be attributed to the presence of fatty acids (Kamenarska et al. 2004; Laungsuwon and Chulalaksananukul 2014; Stabili et al. 2014; Zbakh et al. 2014). Stabili et al. (2014) found that $\alpha$-linolenic acid, which was the predominant n-3 fatty acid in the extract obtained from marine C. rupestris, could be involved in the antibacterial activity. Besides fatty acids, Laungsuwon and Chulalaksananukul (2014) reported that Cladophora extracts contained also other compounds such as alkanes, phenols, imidazole, 2-amino-5-[(2-carboxy)vinyl]-, 2,4-di-tertbutylphenol, and dihydroactinidiolide. Antifungal and antibacterial properties of Cladophora extracts can be also due to the presence of thymol, which is widely used in cosmetics (Horincar et al. 2014). As can be seen from Table 7b, much more is known about the antimicrobial activity of marine algae than freshwater.

Scientists are also looking for other properties of Cladophora extracts that could be used in the prevention and treatment of numerous diseases and ailments. In Table 7c, few examples of anticancer activity of Cladophora extracts are presented, which concern human breast adenocarcinoma cell line (Lezcano et al. 2018) and human colon carcinoma (Zbakh et al. 2014; Karan and Erenler 2018). Extracts from Cladophora (produced mainly with methanol and hexane) exhibited inhibition of proliferation of cells in a dose- and time-dependent manner. Antioxidant properties of Cladophora extracts are of great importance in the prevention and treatment of cancer. The high concentration of phenols in algal extracts exhibits strong DPPH radical scavenging activity whereby they have the ability to neutralize free radicals, which can trigger cancer cells (Laungsuwon and Chulalaksananukul 2013). Moreover, Cladophora extracts could protect from many other diseases (Amornlerdpison et al. 2011). Cladophora glomerata extract, obtained by blending and boiling at $100{ }^{\circ} \mathrm{C}$ for $1 \mathrm{~h}$, exhibited also antidiabetic and renoprotective effects what was shown in the experiments on rats with type 2 diabetes mellitus (Srimaroeng et al. 2015). The authors showed that it was possible due to restoration of pathogenic consequences, including antihyperglycemia, antihypertriglyceridemia, anti-insulin resistance, and restoration of insulin-stimulated renal rOat (rat organic anion transporter) 1 and 3 functions. Cladophora glomerata extract, obtained by boiling at $100{ }^{\circ} \mathrm{C}$ for $2 \mathrm{~h}$, presented anti-inflammatory activity in ethyl phenylpropiolate-induced ear edema and carrageenan-induced hind paw edema in rats (Amornlerdpison et al. 2011).

Cladophora species exhibit several activities that are listed in Table 7, but as it was underlined by many authors, there is a need to isolate and identify the active chemical compounds which are responsible for these properties (Sheikh et al. 2009; Soltani et al. 2011; Laungsuwon and Chulalaksananukul 2013; Karan and Erenler 2018). It will lead to their potential applications in medicine, cosmetic industry, and food production.

\section{Cosmetic applications}

Macroalgae are also of great importance in the cosmetics industry. As it was shown in the work of Fabrowska et al. (2015), Cladophora species contain compounds of cosmetic applications, such as fatty acids (e.g., linoleic acid), steroids (e.g., $\beta$-sitosterol), carotenoids (e.g., $\beta$-carotene), polyphenols (e.g., eckol), terpenoids (e.g., trans-phytol), carbohydrates, and vitamins (e.g., ascorbic acid) which exhibit many activities such as antioxidative, antiallergic, antibacterial, anti-inflammatory, photoprotective, moisturizing, anti-wrinkle, firming, regulating keratinization processes, regenerating, and rejuvenating. It is important to choose the best extraction process that will guarantee the extraction of selected biologically active compounds and the preservation of their activity. Messyasz et al. (2015a) showed that the extract obtained from C. glomerata using supercritical fluid extraction with carbon dioxide can be used as a component of cosmetics, for example creams, masks, and scrubs. Cladophora extracts can find application in the whole range of cosmetic products, for example creams to dry, sensitive skin; anti-wrinkle and moisturizing creams; creams for vascular skin; creams to sensitive and allergic skin; anti-acne and anti-aging cosmetics; make-up cosmetics; antiallergic preparations; puryfying gels; firming balms; and anti-dandruff shampoos. (Fabrowska et al. 2015). In the in vivo studies, it was confirmed that $C$. glomerata extract obtained by supercritical fluid extraction affected positively the stability of prepared cosmetic emulsions and additionally improved the skin hydration and its elasticity (Fabrowska et al. 2017).

\section{Fertilizers and biostimulants for plant growth}

Cladophora biomass, derived from the eutrophied water reservoirs and remediation of wastewater from aquaculture, 
Table 7 Activities of Cladophora species

\section{(a) Antioxidant activity}

Species

C. prolifera, C. vagabunda (M)

C. glomerata (M)

\section{Form of algae}

Extract: extraction of lyophilized algae twice, dichloromethanol: methanol (2:1), $20 \mathrm{~h}$

Extract: maceration with $70 \%$ repeated 2 times ethanol, $1 \mathrm{~h}$ sonication, filtration,

C. prolifera (M) Extract: extraction of freeze-dried alga with methanol in a Soxhlet extractor, $8 \mathrm{~h}$

C. patentiramea Extract: extraction of ground algae (M)

C. surera $(\mathrm{F})$ with hexane and methanol, stirring, $6 \mathrm{~h}$

\section{Extract: shaking of dried algal} powder with $20 \mathrm{~mL}$ of methanol/water $(80: 20), 25^{\circ} \mathrm{C}$, $3 \mathrm{~h}$

C. glomerata (F) Extract: maceration with methanol and water, $24{ }^{\circ} \mathrm{C}, 24 \mathrm{~h}$

C. glomerata (F) Extract: (1) extraction of freeze-dried alga with methanol, hexane, and ethyl acetate at $25^{\circ} \mathrm{C}$, (2) extraction with boiling deionized water, $1 \mathrm{~h}$

C. glomerata (F) Extract: boiling in a hot water for $2 \mathrm{~h}$, then filtration

C. glomerata (F) Extract: Supercritical fluid extraction with $\mathrm{CO}_{2}\left(\mathrm{SFE}-\mathrm{CO}_{2}\right.$, 500 bar, $40{ }^{\circ} \mathrm{C}$ ) and ultrasound-assisted extraction (UAE, methanol, $1 \mathrm{~h}$, room temperature)

C. glomerata (F) Extract: mixing of algae powder with distilled water or ethanol (E $20,40,60,80$, or $100 \%, \mathrm{v} / \mathrm{v})$, homogenization (2 $\mathrm{min})$, stirring, $12 \mathrm{~h}, 25-28^{\circ} \mathrm{C}$, centrifugation

\section{Results}

- Phenolic content: C. prolifera $1.95 \pm 0.12$, C. vagabunda $1.02 \pm 0.08$ (\% dry wt)

- DPPH radical scavenging activity: $\mathrm{EC}_{50}\left(\mathrm{mg} \mathrm{mL}^{-1}\right)$ C. prolifera 16.7 , C. vagabunda 23.2

- Total phenolic contents: $3077 \pm 105 \mathrm{mg} \mathrm{GAE} \mathrm{g}^{-1}$ of extract (Folin-Ciocalteau reagent)

- Total flavonoid contents: $595 \pm 23 \mathrm{mg}$ quercetin equivalent $\mathrm{g}^{-1}$ of extract

- DPPH scavenging activity: $\mathrm{IC}_{50}=920 \pm 42 \mu \mathrm{g} \mathrm{mL} \mathrm{L}^{-1}$

- Iron chelating activity: $\mathrm{IC}_{50}=971 \pm 39 \mu \mathrm{g} \mathrm{mL}^{-1}$

- Nitric oxide-scavenging activity: $\mathrm{IC}_{50}=0.20 \pm 0.01 \mathrm{mg} \mathrm{mL}^{-1}$

- ABTS radical scavenging activity - the percentage of inhibition of $\mathrm{ABTS}^{+}$radical cation was $97.8 \%$ for Trolox and $70.3 \%$ for C. prolifera extract, at the concentration of $200 \mu \mathrm{g} \mathrm{mL}$

- Total phenolic content: hexane $9.62 \pm 0.40$, methanol $15.6 \pm 0.24 \mathrm{mg}$ $\mathrm{GAE} \mathrm{g}^{-1}$ of extract

- DPPH radical scavenging activity for $2 \mathrm{mg} \mathrm{mL}^{-1}$ : hexane $29.8 \%$, methanol $48.7 \%$

- Total phenolic content: $1.6 \pm 0.2 \mu \mathrm{g} \mathrm{GAE} \mathrm{mg}^{-1}$ of dry alga (Folin-Ciocalteau reagent)

- DPPH scavenging activity: $25 \pm 2 \%$

- Total phenol content: water $-0.044 \pm 0.002 \mathrm{mg} \mathrm{GAE} \mathrm{g}^{-1}$ sample; methanol- $0.047 \pm 0.001 \mathrm{mg} \mathrm{GAE} \mathrm{g}^{-1}$ sample

- DPPH scavenging activity: $\mathrm{IC}_{50}=33.97 \pm 3.21 \mu \mathrm{g} \mathrm{mL}{ }^{-1}$ of water extract; $\mathrm{IC}_{50}=29.85 \pm 4.31 \mu \mathrm{g} \mathrm{mL}^{-1}$ of methanol extract

- Total phenolic content: methanol-12.6 \pm 0.8 ; hexane $-15.7 \pm 1.9$; ethyl acetate $-18.1 \pm 2.3$; water $-13.9 \pm 1.1 \mathrm{mg} \mathrm{GAE} \mathrm{g}^{-1}$ dry weight

- DPPH scavenging activity: methanol $-16.7 \pm 2.6$; hexane $-37.4 \pm 2.3$; ethyl acetate $-49.8 \pm 2.7$; water $-18.4 \pm 2.5 \%$; ascorbic acid as control- $89.8 \pm 3.2 \%$

- Total phenolic content: $184 \pm 2 \mathrm{mg} \mathrm{GAE} \mathrm{g}^{-1}$ of extract

- DPPH radical scavenging activity: $\mathrm{EC}_{50} 11.8 \mathrm{mg} \mathrm{mL}^{-1}$

- Scavenging activity of superoxide radicals: $73 \% ; \mathrm{EC}_{50} 6.41 \mathrm{mg} \mathrm{mL}$

- Lipid peroxidation assay: $66 \%, \mathrm{EC}_{50} 21.8 \mathrm{mg} \mathrm{mL}^{-1}$

- Total phenolics [mg GAE g ${ }^{-1}$ ]: SFE- $\mathrm{CO}_{2}-25.2 \pm 1.1$; UAE$21.5 \pm 1.7$

- Total flavonoids [mg QE (quercetin equivalents) $\mathrm{g}^{-1}$ ]: SFE- $\mathrm{CO}_{2}-$ $1.08 \pm 0.04 ; \mathrm{UAE}-1.77 \pm 0.10$

- Activity towards DPPH for $200 \mu \mathrm{L}$ of sample [\%]: SFE- $\mathrm{CO}_{2}-$ $66.5 \pm 2.3$; UAE- $65.2 \pm 2.6$

- Concentration of antioxidant $-\mathrm{C}$ [mg TEAC $\left.100 \mathrm{~mL}^{-1}\right]$ : SFE-CO ${ }_{2}-$ $6.89 \pm 0.30 ; \mathrm{UAE}-6.73 \pm 0.33$

- Total phenolic content - the highest for E 40 and E $60 \sim 11 \mathrm{~g} \mathrm{GAE} \mathrm{kg}^{-1}$ solids, the lowest for $\mathrm{E} 80 \sim 6 \mathrm{~g} \mathrm{GAE} \mathrm{kg}^{-1}$ solids

- DPPH radical scavenging activity: increased with the concentration of ethanol until 60\% 18 $\mu \mathrm{mol}$ Trolox equivalents (TE) $\mathrm{g}^{-1}$ solid (the highest value), the lowest for E 20 6 $\mu \mathrm{mol} \mathrm{TE} \mathrm{g}^{-1}$ solid

- ABTS radical scavenging activity: E 60 showed the highest ABTS radicals scavenging activity $\sim 170 \mu \mathrm{mol} \mathrm{TE} \mathrm{g}^{-1}$ solid, the lowest for $\mathrm{E}$ 20 60 $\mu \mathrm{mol} \mathrm{TE} \mathrm{g}^{-1}$ solid

- Ferric reducing antioxidant power (FRAP): the highest for $\mathrm{E}$ 60 15 $\mu \mathrm{mol} \mathrm{TE} \mathrm{g}^{-1}$ solid, the lowest for E $80 \sim 8 \mu \mathrm{mol} \mathrm{TE} \mathrm{g}^{-1} \mathrm{~g}$ solid

- Metal chelating activity: the highest for E $60 \sim 40 \mu \mathrm{mol}$ EE (EDTA equivalent) $\mathrm{g}^{-1}$ solid, the lowest for water extract $\sim 2 \mu \mathrm{mol}$ EE (EDTA equivalent) $\mathrm{g}^{-1}$ solid

- Total phenolic content: C. glomerata $17.3 \pm 0.2 \mathrm{mg} \mathrm{GAE} \mathrm{g}^{-1}$, C. fracta $11.6 \pm 0.2 \mathrm{mg} \mathrm{GAE} \mathrm{g}^{-1}$

\section{Reference}

(Zubia et al. 2007)

(Soltani et al. 2011)

(Zbakh et al. 2014)

(Sheikh et al. 2009)

(Lezcano et al. 2018)

(Akköz et al. 2011)

(Laungsuwon and Chulalaksananukul 2013)

(Amornlerdpison et al. 2011)

(Messyasz et al. 2018b)

(Yarnpakdee et al. 2019)

(Pikosz et al. 2019) 
Table 7 (continued)

(b) Antibacterial activity

\section{Macroalga Form of algae}

C. glomerata Extract: maceration with $70 \%$

(M)

ethanol, $1 \mathrm{~h}$ sonication, filtration, repeated 2 times
C. vagabunda (M)
Fatty acid obtained from crude oils extracted from C. vagabunda, sonication, hexane
C. prolifera (M) Extract: extraction of freeze-dried Disk diffusion method and Broth alga with methanol, toluene-ethanol microdilution assay: (1:1), ethanol, Soxhlet extractor, 8 h Escherichia coli (ATCC 25922),

C. rupestris (M) Extract: Soxhlet extraction of powdered algae tissues with chloroform/methanol

C. glomerata (M)

C. crispata (F) Extract: different solvents (cold water, hot water, acetone, chloroform, petroleum ether, ethanol, methanol, toluene); mixing Pseudomonas aeruginosa, of algal powder and homogenization with solvents, shaking overnight, $25^{\circ} \mathrm{C}$

C. glomerata (F) Extract: extraction of freeze-dried macroalgal with (1) hexane, ethyl acetate and methanol at room temperature and re-extracted twice with the same solvent (2) with boiling deionized water, $1 \mathrm{~h}$
Method used

Disc diffusion method:

Bacillus subtilis,

Staphylococcus aureus, Proteus mirabilis,

Pseudomonas aeruginosa

Salmonella typhimurium

The microdilution method:

Bacillus cereus,

Listeria monocytogenes,

Escherichia coli,

Salmonella enteritidis

Staphylococcus aureus (ATCC 25923),

Staphylococcus aureus (ATCC 29213),

Enterococcus faecalis (ATCC 29212),

Klebsiella pneumoniae (ATCC 700603)

\section{Results}

- S. aureus - inhibition zone from

$8.7 \mathrm{~mm}$ (for $7.25 \mathrm{mg} \mathrm{mL}^{-1}$ ) to

$22.5 \mathrm{~mm}$ (for $100 \mathrm{mg} \mathrm{mL}^{-1}$ ) - better than $B$. subtilis

- P. mirabilis - inhibition zone from

$12 \mathrm{~mm}$ (for $25 \mathrm{mg} \mathrm{mL}^{-1}$ ) to

$15 \mathrm{~mm}$ (for

$100 \mathrm{mg} \mathrm{mL}^{-1}$ ) - better than

S. typhimurium

- P. aeruginosa - no activity

- Seaweed oil extracts had

substantial antimicrobial potential

- The minimum inhibitory

concentrations of $C$. vagabunda fatty acid extracts varied from 1.8 to $3.8 \mathrm{mg} \mathrm{mL}^{-1}$ for all bacterial strains

- Methanolic extract showed the major activity against $S$. aureus

(ATCC 25923), moderate against

E. coli and low activity against

$K$. pneumoniae and E. faecalis, no activity against $S$. aureus (ATCC

29213)

- Toluene-ethanol extract showed activity only against $S$. Aureus (ATCC 25923)

- Ethanol extract - inactive against all microorganisms

Disc diffusion assay:

Pseudomonas aeuriginosa,

Enterococcus sp.,

Streptococcus agalactiae,

Vibrio salmonicida, Vibrio

fluvialis, Vibrio metschnikovii,

Vibrio vulnificus, Vibrio ordalii,

Vibrio cholerae non-OI

Disc diffusion assay:

Acinetobacter baumannii,

Vibrio parahaemolyticus,

$V$. fischeri,

V. vulnificus,

Bacillus cereus,

Escherichia coli

Agar well diffusion method:

Escherichia coli,

Bacillus subtilis,

Salmonella typhi

Bacillus cereus,

Vibrio parahaemolyticus,

Staphylococcus aureus,

Escherichia coli,

Salmonella typhimurium
- Algal extract in ethanol

(5 $\mathrm{mg} \mathrm{mL}^{-1}$ )-activity only against Vibrio: $V$. fluvialis (inhibition zone

$0.9 \mathrm{~cm})$ V. ordalii $(8 \mathrm{~mm})$,

$V$. cholerae non-O1 (8 mm),

V. metschnikovii $(8 \mathrm{~mm})$,

V. salmonicida $(9 \mathrm{~mm})$,

V. vulnificus $(9 \mathrm{~mm})$

- Crude extract $\left(200 \mu \mathrm{g} \mathrm{mL}^{-1}\right)$ - the (Yuvaraj et al.

highest activity against

A. baumannii $(15 \mathrm{~mm})$,

V. anguillarum $(12 \mathrm{~mm})$,

V. vulnificus $(11 \mathrm{~mm}), 9 \mathrm{~mm}$ for

B. cereus, E. coli,

$V$. parahaemolyticus, $V$. fischeri

- Activity for the concentration of extract $20 \mathrm{mg} 5 \mu \mathrm{L}^{-1}$.

E. coli: chloroform, petroleum ether, toluene

B. subtilis: acetone

P. aeruginosa: no activity of extracts

S. typhi: petroleum ether

- Activity for the concentration of extract $200 \mu \mathrm{g} \mathrm{mL}^{-1}$ :

Staphylococcus aureus: hexane; Vibrio parahaemolyticus: ethyl acetate and methanol

Other bacterial strains - lack of activity of Cladophora extracts Jadhav 2015)
Reference

(Soltani et al. 2011)

(Horincar et al.

2014)

(Zbakh et al. 2014)

(Stabili et al. 2014)
(Mahadik and

(Laungsuwon and Chulalaksananukul 2014) 
Table 7 (continued)

(c) Anticancer activity

$\begin{array}{ll}\text { Macroalga } & \text { Form of algae } \\ \text { C. } \operatorname{surera}(\mathrm{F}) & \text { Extract: shaking of dried algal } \\ & \text { powder with } 20 \mathrm{~mL} \text { of methanol/ } \\ & \text { water }(80: 20), \text { room temperature, } \\ & 3 \mathrm{~h}\end{array}$

C. $\operatorname{fracta}(\mathrm{F}) \quad$ Extract: extraction of powdered alga with hexane for $24 \mathrm{~h}$. Reextraction of $C$. fracta hexane extract with methanol
Method used

Human breast adenocarcinoma cell - Significant inhibition of line MCF-7 (Trypan blue uptake, cell viability assay (MTS), woundhealing migration assay, adhesion assay)

Human colon carcinoma (HT29) and non-tumorigenic African green monkey kidney (Vero) cell lines

\section{Results}

of extract) extract extract and Vero cell lines
Human oral cavity cell lines

(KB) _ resazurin microplate assay (REMA); cytotoxicity against normal cell lines-African green monkey kidney (Vero) cell lines proliferation of cells in a dose-

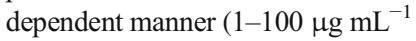

- Significant decrease in cell viability at $100 \mathrm{~g} \mathrm{~m} \mathrm{~mL}^{-1}$ of

- Inhibition of cell migration by

- Considerable influence of extract on the cell adhesion capacity

- Methanol extract had strong antiproliferative activity on HT29

- Hexane extract had good antiproliferative activity at high concentrations on both cell lines

- Both extracts had low effect on HT29 cell at low concentrations in cytotoxicity test

- Inhibition of the growth

(hB cell lines in Chulalaksananukul

tissue culture and a significant de-

crease in the total cellular metabolic (reductase) activity (number of viable cells) was observed only for the hexane and ethyl acetate extracts (not for more polar methanol and hot water extract)

- IC $_{50}$ of ethyl acetate $(1420 \pm$ $\left.66 \mu \mathrm{g} \mathrm{g}^{-1}\right)$ and hexane (1662 \pm $48 \mu \mathrm{g} \mathrm{g}^{-1}$ ) extracts against the KB cell lines

- $\mathrm{IC}_{50}$ of ethyl acetate (2622 \pm $\left.44 \mu \mathrm{g} \mathrm{g}^{-1}\right)$ and hexane $(2574 \pm$ $30 \mu \mathrm{g} \mathrm{g}^{-1}$ ) against the Vero cell lines

$\begin{array}{lll}\text { C. prolifera (M) } & \begin{array}{l}\text { Extract: extraction of freeze-dried } \\ \text { alga with methanol, Soxhlet extrac- }\end{array} & \begin{array}{l}\text { Human colon cancer cells (HT29); } \\ \text { sulforhodamine-B (SRB) assay }\end{array}\end{array}$ tor, $8 \mathrm{~h}$
Reference

(Lezcano et al. 2018)

(Karan and Erenler 2018)

2013)

(Zbakh et al. 2014) C. prolifera extract exhibited a dose $(6.25,12.5,25,50$, $\left.100 \mathrm{Mg} \mathrm{mL}^{-1}\right)$ and time-dependent (48 and $72 \mathrm{~h}$ ) inhibitory effect on the cancer cell growth

$I C_{50}$ extract concentrations resulting in a $50 \%$ inhibition, n.a. data not available

which is rich in nitrogen and phosphorus can constitute a raw material for the production of organic fertilizers, soil ameliorants, and biostimulants for plant growth (Bird et al. 2011). By transforming the algal biomass into products useful for agriculture, it is possible to recover fertilizing elements, especially nitrogen and phosphorus. It is one of the elements of Circular Economy. Freshwater $C$. glomerata can serve as a source of fertilizer ingredients such as macroelements - magnesium, potassium, sodium, and microelement-iron (Messyasz et al. 2015a) (Table 6). Biomass of Cladophora can be used in solid form (fertilizer, soil amendment) or liquid as algal extracts used as biostimulants of plant growth. There are several methods of application of Cladophora extracts in plant cultivation - directly to soil, as a foliar spray (Michalak et al. 2017a, 2019a), or pre-treatment of seeds before sowing (Michalak et al. 2017a, 2018a). The mixture of Baltic seaweeds, containing green algae-Cladophora glomerata, Ulva clathrata (Roth) Agardh, Ulva flexuosa Wulfen, and the red alga Vertebrata fucoides (Hudson) Kuntze- - was used for the production of organic compost (Michalak et al. 2017b, 2017c). This compost had no phytotoxic effect on plant growth (garden cress (Lepidium sativum) and radish (Raphanus sativus)), increased weight of plants, and biofortifed them with micro- (B, Cu, Fe, Zn) and macroelements (Ca, K, S) (Michalak et al. 2017c). Additionally, the risk of odor nuisance during composting of algae was excluded (Michalak et al. 2017b). 
More often, Cladophora biomass is used in the liquid form. In the work of Cavallo et al. (2006), marine C. prolifera, after drying and grinding, was used to prepare fertilizer for tomatoes. The algal powder was mixed with water in order to obtain two concentrations - 5 and $10 \%$. Field experiments showed that the total production and percentage of plant survival were higher for both experimental groups than for the control group, but lower concentration of fertilizer gave better result (Cavallo et al. 2006). Michalak et al. (2017a) produced from the mixture of Baltic seaweeds (C. glomerata, $U$. clathrata, $U$. flexuosa, V. fucoides) algal filtrate for seed soaking before sowing and as a liquid biostimulant for foliar application and homogenate for seed coating. The examined products stimulated plant growth and yield and increased the content of elements in radish seedlings. Additionally, it was shown that algal products have very good complexing properties of metal ions ( $\mathrm{Zn}$ (II) ions). The same mixture of Baltic algae was used in a microwave-assisted extraction. Germination tests with algal extracts $(0.5,2.5$, and $10 \%)$ showed that garden cress (Lepidium sativum L.) in the experimental groups had higher weight, height, chlorophyll, and micro- and macroelement content than plants in the control group. Moreover, algal extracts had no negative influence on the morphology of plants as shown by scanning electron microscopy (Michalak et al. 2015). Another novel extraction technique - supercritical fluid extraction with carbon dioxide as a solvent — enabled isolation of organic (polyphenols, plant hormones: auxins and cytokinins) and inorganic (macro- and microelements) compounds from the Baltic Sea macroalgae (species of Cladophora, Ulva, Vertebrata). It is worth mentioning that heavy metals are not extracted from the biomass using this technique. Supercritical extract enhanced chlorophyll and carotenoid content in plant shoots (garden cress (Lepidium sativum) and wheat (Triticum aestivum L.)), as well as aboveground biomass and root thickness (Michalak et al. 2016a). The positive effect of supercritical algal extracts obtained from algae from the Baltic Sea on the growth and development of plants was later confirmed in the field experiments on winter wheat (Michalak et al. 2016b). Michalak et al. (2018a) showed also that Cladophora extracts stimulated the chlorophyll content in soybean seedlings. In the case of soybean seeds, their soaking in an extract before sowing did not increase germination, because many of the seeds were classified as abnormal due to their swelling during maceration in algal extract. Therefore, other methods of algal extract for big seeds such as soybean are recommended. Application of water extract of $C$. glomerata directly to the filter paper and then sowing of soybean seeds, increased both the number of germinated seeds and the content of chlorophyll in seedlings (Michalak et al. 2019a).

Extracts from Cladophora species can also act as natural biofungicides. Nowadays, safe and ecofriendly alternatives to chemical pesticides that control plant diseases are intensively searched for. The methanol extract of C. glomerata was found to be active against two types of plant fungi, Pythium altimum Trow and Rhizoctonia solani Kühn, which cause diseases in cucumber. For the concentration of algal extract$50 \mathrm{mg} \mathrm{mL}^{-1}$ - the inhibition of P. altimum was $84 \%$ and R. solani, $100 \%$ (Mohammed et al. 2014). The antiphytopathogenic activity exhibited also ethanolic extracts from C. glomerata and C. albida. Both extracts at concentration $50 \mathrm{mg} \mathrm{mL}^{-1}$ showed a high activity-inhibition of Fusarium oxysporum that causes diseases on date palm (Phoenix dactylifera L.) which was $94 \%$ for C. glomerata and $89 \%$ for C. albida (Douma et al. 2017). This activity was probably due to the content of phenols, flavonoids, alkaloids, and tannins (Mohammed et al. 2014; Douma et al. 2017). Mahadik and Jadhav (2015) showed that Cladophora extracts obtained with different solvents (cold and hot water, acetone, chloroform, ethanol, methanol, petroleum ether, toluene) can be active against many other fungal strains.

Another potential end-use for Cladophora biomass is the production of biochar through pyrolysis, which can be also used in agriculture. In pyrolysis, biofuels such as gas and biooil are also obtained (Bird et al. 2011; Chaiwong et al. 2012; Michalak et al. 2019b). During pyrolysis of freshwater Cladophora at $550{ }^{\circ} \mathrm{C}$, the following products were obtained-gas (30\%), bio-oil (39\%), and biochar (31\%) (Chaiwong et al. 2012). Algal biochar is recognized as a tool for carbon sequestration, as well as soil amendment/ ameliorant that improves water holding capacity and nutrient status of soil, and enhances microbial activity in the root system (Bird et al. 2011; Chaiwong et al. 2012). Additionally, Cladophora biochar contains also inorganic nutrients such as Ca, Mg, P, and K (Bird et al. 2011; Chaiwong et al. 2012).

\section{Feed additives}

The content of compounds such as proteins, amino acids, lipids, and elements in Cladophora species is similar to plants that are used as a feed material, therefore, algae can be also used as a valuable feed additive (Heiba et al. 1997). Cladophora biomass shows very interesting content of amino acids (Messyasz et al. 2015a).

Cladophora species are more often used as feed additives for aquaculture, than for livestock. In aquaculture, it is considered a fish meal replacement or protein supplement. For example, in the work of Anh et al. (2018), Cladophora spp. was used as a protein source in the diet for postlarval tiger shrimp (Penaeus monodon). Macroalga constituted a substitute of fishmeal protein. In order to provide the optimal performance, including growth rate, feed efficiency, and stress resistance, shrimp diet should be supplemented with $10-20 \%$ of algae (Anh et al. 2018). Cladophora glomerata was also tested as a protein source for Sarotherodon (Tilapia) niloticus fingerlings. The highest growth rate and best protein utilization was 
observed in a group fed with the diet in which the ratio of fishmeal protein to $C$. glomerata meal protein was 25:5. The highest protein digestibility was observed in a group with the ratio 25:5 $(94.5 \%)$ and 20:10 $(93.9 \%)$. When the content of algal protein increased $(25: 5 ; 20: 10 ; 15: 5 ; 10: 20 ; 0: 25)$, weight gain, protein utilization, and the content of lipids and proteins in carcass decreased (Appler and Jauncey 1983). Promya and Chitmanat (2011) examined the effect of Cladophora supplementation to the diet of the African sharptooth catfish (Clarias gariepinus) on the growth performance and meat quality. The addition of $5 \%$ of Cladophora to the basal diet resulted in the enhancement of the carotenoid levels in the catfish. This additive increased also weight gain, average daily growth, and survival rate. Flesh of sharptooth catfish after 60 days contained higher amounts of proteins, carbohydrates, and ash, but lower of fat and fiber when compared with fish fed with the basal diet.

The biomass of Cladophora species can also serve as a carrier of microelements in the animal diet. Michalak et al. (2018b) showed that Cladophora biomass additionally enriched with microelement ions via biosorption can become a valuable feed additive for different breeds of animals and can partially replace traditionally used inorganic salts. In the work of Michalak et al. (2011), it was shown that the mixture of marine biomass of Ulva prolifera and Cladophora sp. enriched with $\mathrm{Cu}(\mathrm{II}), \mathrm{Zn}(\mathrm{II}), \mathrm{Co}(\mathrm{II}), \mathrm{Mn}$ (II), and $\mathrm{Cr}$ (III) ions via biosorption, when applied to the diet of laying hens, increased the content of these elements in eggs, and enhanced the color of yolk, egg weight, and eggshell thickness as well as body weight of hens, when compared to the control group, where inorganic salts were used.

In animal feeding, the biomass of Cladophora can be also used as extracts, which have promising antioxidant, anti-inflammatory, and immunomodulatory effects. Therefore, these formulations have potential to be used in the prevention of many diseases in animals. Marycz et al. (2017) found that methanolic extract obtained from freshwater C. glomerata, which was previously enriched with $\mathrm{Cr}$ (III) ions, reduced the apoptosis and inflammation in adipose-derived mesenchymal stem cells of horses diagnosed with equine metabolic syndrome. It was possible due to improvement of mitochondrial dynamics, decreasing of pyruvate dehydrogenase kinase 4 expression and reduction of endoplastic reticulum stress. C. glomerata enriched with $\mathrm{Cr}$ (III) ions induced also antioxidative protection as a result of enhanced superoxide dismutase activity. Cladophora species can serve not only as a source of micro- and macroelements for animals, but also as a therapeutic agent in the pharmacological treatment of animal diseases (e.g., EMS in horses). Bourebaba et al. (2019) showed that methanolic extract from freshwater C. glomerata decreased oxidative stress and improved viability and mitochondrial potential in equine adipose-derived mesenchymal stem cells (ASCs). Treatment of these cells with algal extract at doses
1 and $5 \%$, protected them against cellular damage caused by $\mathrm{H}_{2} \mathrm{O}_{2}$.

Cladophora extracts are characterized by very good antimicrobial properties, which is shown in Table 7b. Since the use of antibiotics to control pathogens in shrimp and fish culture is banned, Yuvaraj et al. (2011) proposed to use methanolic extract obtained from $C$. glomerata to control these microorganisms. Long-chain hydrocarbons (e.g., pentadecane, 8-hexyl-; heptadecane, 9-hexyl- and tridecane, 8-hxyl-) detected in the algal extracts may act as potential antimicrobial substances.

\section{Cladophora species as bioaccumulators/bioindicators}

Macroalgae are used as bioaccumulators/bioindicators of water pollution because their biomass is ubiquitous, has very simple growth requirements, and therefore grows easily and colonizes water reservoirs all over the world (Sobhan and Sternberg 1999). Moreover, Cladophora species are easily collected due to sedentary habits, are relatively widespread in different water reservoirs, and have simple morphology and adequate tissues for analysis (Żbikowski et al. 2007).

Macroalgae, including Cladophora species, due to their ability to accumulate pollutants (e.g., heavy metals, pesticides, halogenated hydrocarbons, polychlorinated biphenyls, dioxins, organochlorines, carbamates) are very often used in the environmental monitoring (Sobhan and Sternberg 1999; Żbikowski et al. 2007; Akin and Ünlü 2013; Bačkorová et al. 2016; Ebadi and Hisoriev 2017). There are many point and nonpoint sources of these contaminants, but the main source of nutrients in water is the application of mineral fertilizers, whereas of toxic metals - all branches of industry. The production of large amounts of the biomass by Cladophora is a visible manifestation of eutrophication of water reservoirs (Parker and Maberly 2000). Cladophora species are known as the best bioindicators of aquatic environments which are contaminated with nutrients (nitrogen, phosphorus) and toxic metals (e.g., As, Cd, Cr, Hg, Ni, Pb, V) (Chmielewská and Medved' 2001; Żbikowski et al. 2007; Ebadi and Hisoriev 2017).

Bioaccumulation of pollutants by macroalgae is affected by various abiotic and biotic factors. Cladophora sp. is known as a good scavenger of toxic metal ions in a short time, but it depends on several factors such as algal size, age, stage in life history, and chemical composition of algae, as well as concentration of metal ions in water, its $\mathrm{pH}$, salinity, light, temperature, particulate and organic matter, and chemical species in aqueous solution (Sobhan and Sternberg 1999; Choo et al. 2002; Akin and Ünlü 2013; Ebadi and Hisoriev 2017). During bioaccumulation, toxic metal ions (e.g., $\mathrm{Cd}(\mathrm{II})$ ions) can be accumulated in the cell wall of $C$. rupestris (Zhang et al. 2019). The high affinity of Cadophora species for heavy 
metal cations results from the high negative surface charge (Chmielewská and Medved' 2001).

The advantage of Cladophora species is high bioconcentration of toxic metals at low external concentration which is important for phytoremediation - in a cost-effective manner, it is possible to treat large volumes of wastewater with low concentrations of pollutants (Lamai et al. 2005; Jasrotia et al. 2014). Therefore, $C$. glomerata can be used for the removal of nutrients, pesticides, and toxic metals from the agricultural streams, and industrial and domestic wastewaters (Chmielewská and Medved' 2001; Shelton and Miller 2002; Ji et al. 2012).

Biomass of macroalgae easily removes nutrients from the polluted waters and during bioremediation not polluted and exploitable alga biomass is generated, which can be used for the production of fertilizers, feed additives, and biofuels (Giangrande et al. 2007; Ross et al. 2018). This phytoremediation results in both economic and environmental advantages. Cladophora glomerata was shown to remove ammonium (preferred nitrogen source for the growth of macroalgae) from wastewater derived from aquaculture systems (e.g., fish farms) (Giangrande et al. 2007). In this work, it was shown that marine $C$. glomerata exposed to high ammonium concentration in water $(34 \mu \mathrm{M})$ removed $78 \%$ of ammonium during the first hour of experiment.

Cladophora species are characterized by a high tolerance to toxic metal ions such as $\mathrm{Pb}, \mathrm{Cu}$, and $\mathrm{Zn}$ (Żbikowski et al. 2007). Macroalgae have developed a number of defense mechanisms against high concentrations of toxic metals; for example, cell wall sequestration, chemical morphological transformation, and vacuolar compartmentalization are the main mechanisms of the stress tolerance of $C$. rupestris exposed to Cd(II) ions (Zhang et al. 2019). Sobhan and Sternberg (1999) showed that Cladophora grew continuously even if it was exposed to high concentrations of cadmium $\left(5 \mathrm{mg} \mathrm{L}^{-1}\right.$ ). Living Cladophora sp. can be also used for the phycoremediation of arsenic-enriched water, because this alga can survive in an arsenic concentration of up to $6 \mathrm{mg} \mathrm{L}^{-1}$ in water. When the biomass content in the solution was $80 \mathrm{~g} \mathrm{~L}^{-1}$, Cladophora can bind almost $100 \%$ of arsenic from water in a period of up to 9-10 days (Jasrotia et al. 2014). Ji et al. (2012) tested $C$. fracta as a bioaccumulator of $\mathrm{Cd}(\mathrm{II}), \mathrm{Cu}(\mathrm{II}), \mathrm{Zn}(\mathrm{II})$, and $\mathrm{Hg}$ (II) ions. It was shown that the living alga accumulated $2.4 \mathrm{mg}$ of $\mathrm{Cu}$ (II) (removal efficiency 99\%), $1.6 \mathrm{mg}$ of $\mathrm{Zn}$ (II) (85\%), $0.24 \mathrm{mg}$ of Cd(II) (97\%), and $0.23 \mathrm{mg}$ of $\mathrm{Hg}(\mathrm{II})(98 \%)$ per gram of algae $\left(18{ }^{\circ} \mathrm{C}, \mathrm{pH} 5.0\right.$, initial metal ions concentration $\left(C_{0}\right)$ of $\mathrm{Cu}$ (II) and $\mathrm{Zn}$ (II) ions ranged from 1 to $10 \mathrm{mg} \mathrm{L}^{-1}$, while Cd(II) and $\mathrm{Hg}$ (II) from 0.1 to $1.0 \mathrm{mg} \mathrm{L}^{-1}$ ). Akin and Ünlü (2013) showed that C. glomerata accumulated $\mathrm{Cd}(\mathrm{II})$ - it increased with the increase of metal concentration (0.1 and $1.0 \mathrm{mg} \mathrm{L}^{-1}$ ) and exposure time (15 and 30 days). Additionally, it was found that the co-presence of C. glomerata with Nile tilapia (Oreochromis niloticus) in the medium led to a significant $\mathrm{Cd}$ accumulation in the green alga. This suggests that in the bioaccumulation studies, besides abiotic factors, also biotic factors should be taken into account.

Cladophora can concentrate not only inorganic compounds from solutions, but also organic pollutants. Shelton and Miller (2002) showed that $C$. glomerata has the ability to bioconcentrate atrazine, the most commonly used agricultural herbicide to a high degree-yearly about $54 \%$ of the available atrazine from the water. This alga was recommended for the quick biological removal of atrazine from agriculturally polluted rivers.

Cladophora can grow in environment polluted with toxic metal ions, but some concentrations can inhibit growth of this alga. Higher concentrations of toxic metals can evoke toxicity symptoms such as decreased relative growth, damage, reduced number of chloroplasts and total chlorophyll content, disintegrated cell wall, and finally death as it was observed in the case of $C$. fracta exposed to $\mathrm{Pb}$ (concentration until $80 \mathrm{mg} \mathrm{L}^{-1}$ ) and $\mathrm{Cd}$ (concentration until $8 \mathrm{mg} \mathrm{L}^{-1}$ ) for a longer period of time (until 8 days) (Lamai et al. 2005). Cao et al. (2015) showed that the abiotic stress caused by high concentrations of metal ions (e.g., $\mathrm{Zn}$ (II) ions) decreased the photosynthesis of Cladophora and had a negative impact on the content of total soluble sugar and protein in the algal biomass. For $\mathrm{Zn}(\mathrm{II})$ ions, the inhibiting concentration was only $0.25 \mathrm{mg} \mathrm{L}^{-1}$. Additionally, due to oxidative stress, macroalga produced malondialdehydea marker for lipid peroxidation. On the other hand, $\mathrm{Cu}$ (II) ions greatly influence Cladophora growth. Prolonged exposure of marine benthic Cladophora to $\mathrm{Cu}(\mathrm{II})$ ions $(50 \mu \mathrm{M})$ resulted in the increased intracellular copper content in algal thalli. Other changes included decreased content of potassium, alteration of the composition of assimilation pigments, decrease of the content of chlorophyll $a$, and increase of the number of reactive oxygen species (Bačkorová et al. 2016). It is worth remembering that algae as primary producers in aquatic environments bioconcentrate pollutants which can have a negative effect on consumers at higher trophic levels in the trophic pyramid (Shelton and Miller 2002).

The toxic metals can be conveniently removed from the water by simply harvesting the enriched and polluted macroalgae (Sobhan and Sternberg 1999). The resulting algal biomass from wastewater treatment is usually incinerated, but when it has the proper composition (low amounts of toxic metals) can be recommended for composting (Chmielewská and Medved' 2001). It is well known that dead algal cells could sorb more metal ions than living cells; therefore, for wastewater treatment, mainly dry, metabolically inactive biomass is used (Ji et al. 2012). For this purpose, biosorption is used.

\section{Cladophora species as biosorbents}

Many studies have revealed that Cladophora species possess very good biosorption properties - a high metal binding 
capacity (Deng et al. 2006, 2007, 2008, 2009; Tuzen and Sari 2010; Lee and Chang 2011; Rangabhashiyam and Balasubramanian 2018). Biosorption implies a direct interaction between the biosorbent and sorbate (Özer et al. 2005). The ability of macroalgae to bind organic and inorganic contaminants results from the presence of macromolecules in algal cell wall (e.g., polysaccharides) whose functional groups (e.g., carboxyl, hydroxyl, amino, and sulfate) act as binding sites for pollutants (Deng et al. 2006, 2007, 2008).

Biosorption is known as a fast, cost-effective method for removal of toxic metal ions from wastewater (Deng et al. $2008,2009)$, especially when these ions exist in low concentrations and other conventional methods such as ion exchange, precipitation, membrane processes, evaporation, and electroplating are inefficient (Deng et al. 2006). Biosorption of sorbate by Cladophora sp. is influenced significantly by many factors, such as $\mathrm{pH}$, initial metal ion concentration, biosorbent dose, temperature, and presence of coexisting anions (Aksu et al. 1996; Deng et al. 2009; Tuzen and Sari 2010; Lee and Chang 2011; Godlewska et al. 2018). Light metal ions such as $\mathrm{Na}(\mathrm{I}), \mathrm{K}(\mathrm{I}), \mathrm{Mg}(\mathrm{II})$, and $\mathrm{Ca}(\mathrm{II})$ which occur in industrial wastewater can interfere with the uptake of toxic metal ions by algal biomass (Deng et al. 2007).

Cladophora sp. can be used as a sorbent to remove not only inorganic contaminants such as toxic metal ions from wastewater, but also organic such as dyes (e.g., malachite green) (Rangabhashiyam and Balasubramanian 2018). As can be seen from Table 8, Cladophora species can be used for the removal of several metal ions, such as $\mathrm{Cd}(\mathrm{II}), \mathrm{Cr}(\mathrm{III}), \mathrm{Cr}(\mathrm{VI})$, $\mathrm{Cu}(\mathrm{II}), \mathrm{Pb}(\mathrm{II}), \mathrm{Se}(\mathrm{IV}), \mathrm{Zn}(\mathrm{II})$, and U(VI). Therefore, Cladophora sp. can be used in the phycoremediation (Rangabhashiyam and Balasubramanian 2018; Zhang et al. 2019). Differences in biosorption properties of Cladophora species towards metal ions can result from their distinct chemical composition - the differences in the carbohydrate, protein, and lipid content as shown in Table 3.

Usually, biosorption of toxic metals by Cladophora species is performed in a batch system, including continuousstirred tank reactors (Özer et al. 1999; Sternberg and Dorn 2002), two-staged batch reactor (Aksu et al. 1996; Özer et al. 1999, 2000), and packed bed column reactor (Aksu and Kutsal 1998; Aksu et al. 1998; Sternberg and Dorn 2002). Biosorption in packed bed column filled with algal biomass that acts as an ion exchanger is recognized as a technically efficient and economically feasible technology for the removal of metal ions from wastewater (Aksu and Kutsal 1998; Aksu et al. 1998). Biosorption of Cd(II) ions by algal floes of C. crispata in a column depended on the inlet metal ion concentration, the flow rate, and time. Additionally, the appropriate amount of the algal biomass and its particle size affects metal ion removal (Aksu et al. 1998). Usually, Cladophora biomass is used in biosorption as a powder, but in the case of packed bed columns, immobilized cells are recommended, although high costs and lack of mechanical strength of these cells for large-scale system are the major disadvantages (Aksu and Kutsal 1998). Mokone et al. (2018) used Cladophora sp. immobilized in silica gel and alginate beads for the removal of mercury. Sternberg and Dorn (2002) showed that better option for removal of Cd(II) ions by Cladophora species is batch and semi-batch system, where the removal of metal ions is in the range $80-94 \%$ (agitation allowed better contact of algae with $\mathrm{Cd}(\mathrm{II})$ solution), whereas for flow reactor only $13 \%$ (lack of the contact between alga and $\mathrm{Cd}(\mathrm{II})$ solution).

If algal biomass exhibits very good biosorption properties, sorbed metal ions can be removed in desorption using different reagents such as $\mathrm{H}_{2} \mathrm{O}, \mathrm{HNO}_{3}, \mathrm{Ca}\left(\mathrm{NO}_{3}\right)_{2}$, or EDTA (Deng et al. 2006, 2007, 2008; Lee and Chang 2011). Deng et al. (2007) and Deng et al. (2008) found that EDTA was an efficient desorbent of $\mathrm{Cu}$ (II) and $\mathrm{Cd}(\mathrm{II})$ ions from freshwater Cladophora fascicularis. Eluent $\mathrm{HCl}$ was better for desorption of $\mathrm{Se}\left(\mathrm{IV}\right.$ ) from the $C$. hutchinsiae biomass than $\mathrm{HNO}_{3}$ (Tuzen and Sari 2010). Hydrochloric acid was also used for the desorption of $\mathrm{Pb}$ (II) and $\mathrm{Cu}$ (II) ions from enriched Cladophora spp. (Lee and Chang 2011). Generally, Cladophora sp. biomass was considered good biosorbent taking into account the biosorption performance after a large number of sorptiondesorption cycles (Tuzen and Sari 2010).

There are different techniques which are used to characterize biosorption process. FT-IR spectra usually show which Cladophora's functional groups strongly combine with sorbed metal ions (Deng et al. 2007; Tuzen and Sari 2010; Jafari and Senobari 2012; Bağda et al. 2017; Godlewska et al. 2018; Michalak et al. 2018b; Mokone et al. 2018; Rangabhashiyam and Balasubramanian 2018; Amro and Abhary 2019). FT-IR analysis of Cladophora spp. revealed that it has several functional groups that can participate in biosorption-3351 $\mathrm{cm}^{-1}$ : $-\mathrm{OH}$ hydrogen bonded alcohol; $2896 \mathrm{~cm}^{-1}$ : alkyl chains $\left(\mathrm{CH}_{3}\right.$ and $\mathrm{CH}_{2}$ symmetric and asymmetric stretch); $1658 \mathrm{~cm}^{-1}:-\mathrm{C}=\mathrm{O}$ aldehydes, ketones, carboxylic acid; $1429 \mathrm{~cm}^{-1}$ : $-\mathrm{CO}$ bend from carboxylate ions; $1336 \mathrm{~cm}^{-1}$ : amide II (C-N), COO- groups of the fatty acids; 1163 and $1059 \mathrm{~cm}^{-1}$ : $-\mathrm{C}-\mathrm{O}$ stretches, alcohols, ethers, carboxylic acid, esters (Lee and Chang 2011). The scanning electron microscope combined with energy-dispersive X-ray (SEM-EDX) is also beneficial in biosorption studies since it shows the distribution of metal ions on the Cladophora surface before and after biosorption (Bağda et al. 2017; Godlewska et al. 2018; Michalak et al. 2018b).

Not only dry Cladophora can be used as a biosorbent of metal ions, but also products obtained from this biomass, for example biochar in the pyrolysis. Michalak et al. (2019a) showed that the biosorption capacity of biochar towards $\mathrm{Cr}(\mathrm{III})$ ions increased with the temperature in which it was produced-at $300{ }^{\circ} \mathrm{C}$, it was $45.9 \mathrm{mg} \mathrm{g}^{-1}$, whereas at $450{ }^{\circ} \mathrm{C}, 87.1 \mathrm{mg} \mathrm{g}^{-1}$. Such algal biochar can be used not only 
Table 8 Cladophora species as biosorbents of metal ions

\begin{tabular}{|c|c|c|c|c|}
\hline Macroalga & Sorbate & Biosorption conditions & Biosorption capacity $\left(\mathrm{mg} \mathrm{g}^{-1}\right)$ & Reference \\
\hline C. fascicularis $(\mathrm{F})$ & $\mathrm{Cd}(\mathrm{II})$ & $C_{\mathrm{S}} 2 \mathrm{~g} \mathrm{~L}^{-1}, \mathrm{pH} 5,12 \mathrm{~h}, 200 \mathrm{rpm}$ & (L): $112 \mathrm{mg} \mathrm{g}^{-1}$ & (Deng et al. 2008) \\
\hline C. crispata $(\mathrm{F})$ & $\mathrm{Cd}(\mathrm{II})$ & $\begin{array}{l}C_{\mathrm{S}} 1 \mathrm{~g} \mathrm{~L}^{-1} ; C_{0} 100 \mathrm{mg} \mathrm{L}^{-1} ; \mathrm{pH} 3,4, \\
\quad \text { and } 5 ; 2 \mathrm{~h} ; 25^{\circ} \mathrm{C} ; 150 \mathrm{rpm}\end{array}$ & $\begin{array}{l}\text { (L): } \mathrm{pH}^{3}-24.3 \mathrm{mg} \mathrm{g}^{-1}, \mathrm{pH} 4-28.0 \mathrm{mg} \mathrm{g}^{-1} \text {, } \\
\text { pH 5-28.4 } \mathrm{mg} \mathrm{g}^{-1}\end{array}$ & (Özer et al. 1999) \\
\hline Cladophora sp. (F) & $\begin{array}{l}\mathrm{Cd}(\mathrm{II}) \\
\mathrm{Pb}(\mathrm{II})\end{array}$ & $\begin{array}{l}C_{\mathrm{S}} 4 \mathrm{~g} \mathrm{~L}^{-1}, C_{0} 50-500 \mathrm{mg} \mathrm{L}^{-1}, \mathrm{pH} \\
\quad 4,1 \mathrm{~h}, 25^{\circ} \mathrm{C}, 120 \mathrm{rpm}\end{array}$ & $(\mathrm{L}): \mathrm{Cd}-18.9 \mathrm{mg} \mathrm{g}^{-1} ; \mathrm{Pb}-60.9 \mathrm{mg} \mathrm{g}^{-1}$ & $\begin{array}{l}\text { (Amro and Abhary } \\
\text { 2019) }\end{array}$ \\
\hline C. rivularis $(\mathrm{M})$ & $\mathrm{Pb}(\mathrm{II})$ & $\begin{array}{l}C_{\mathrm{S}} 2 \mathrm{~g} \mathrm{~L}^{-1}, \mathrm{pH} 4, C_{0} 5 \mathrm{mg} \mathrm{L}^{-1}, 6 \mathrm{~h}, \\
\quad 25^{\circ} \mathrm{C}\end{array}$ & (L): $48.1 \mathrm{mg} \mathrm{g}^{-1}$ & $\begin{array}{l}\text { (Jafari and Senobari } \\
\text { 2012) }\end{array}$ \\
\hline Cladophora spp. (F) & $\begin{array}{l}\mathrm{Cu}(\mathrm{II}) \\
\mathrm{Pb}(\mathrm{II})\end{array}$ & $\begin{array}{l}C_{\mathrm{S}} 1 \mathrm{~g} \mathrm{~L}^{-1}, \mathrm{pH} 5, C_{0} \\
\quad 50-300 \mathrm{mg} \mathrm{L}^{-1}, 30 \mathrm{~min}\end{array}$ & (L): $\mathrm{Cu}-14.7 \mathrm{mg} \mathrm{g}^{-1} ; \mathrm{Pb}-46.5 \mathrm{mg} \mathrm{g}^{-1}$ & (Lee and Chang 2011) \\
\hline C. fascicularis $(\mathrm{F})$ & $\begin{array}{l}\mathrm{Cu}(\mathrm{II}) \\
\mathrm{Pb}(\mathrm{II})\end{array}$ & $\begin{array}{l}C_{\mathrm{S}} 2 \mathrm{~g} \mathrm{~L} \mathrm{~L}^{-1}, C_{0} 0.2-4.0 \mathrm{mmol} \mathrm{L}^{-1} \\
\mathrm{pH} 5,25^{\circ} \mathrm{C}, 12 \mathrm{~h}, 200 \mathrm{rpm}\end{array}$ & (L): $\mathrm{Cu}-102 \mathrm{mg} \mathrm{g}^{-1} ; \mathrm{Pb}-199 \mathrm{mg} \mathrm{g}^{-1}$ & (Deng et al. 2006) \\
\hline C. fascicularis $(\mathrm{F})$ & $\mathrm{Cu}(\mathrm{II})$ & $\begin{array}{l}C_{\mathrm{S}} 2 \mathrm{~g} \mathrm{~L}^{-1} ; C_{0} 0.2-4.0 \mathrm{mmol} \mathrm{L}^{-1} \\
\mathrm{pH} 5 ; 15,25,35 \text { or } 45^{\circ} \mathrm{C}, 12 \mathrm{~h}\end{array}$ & $\begin{array}{l}\text { (L): } 15^{\circ} \mathrm{C}-47.0 \mathrm{mg} \mathrm{g}^{-1} ; 25^{\circ} \mathrm{C}- \\
70.5 \mathrm{mg} \mathrm{g}^{-1} ; 35^{\circ} \mathrm{C}-92.8 \mathrm{mg} \mathrm{g}^{-1} ; \\
45^{\circ} \mathrm{C}-111 \mathrm{mg} \mathrm{g}^{-1}\end{array}$ & (Deng et al. 2007) \\
\hline C. crispata $(\mathrm{F})$ & $\mathrm{Cu}(\mathrm{II})$ & $\begin{array}{l}C_{\mathrm{S}} 1 \mathrm{~g} \mathrm{~L}^{-1} ; C_{0} 10-100 \mathrm{mg} \mathrm{L}^{-1} ; \mathrm{pH} \\
\quad 4.5 ; 2 \mathrm{~h} ; 15,25 \text {, and } 35^{\circ} \mathrm{C} ; \\
\quad 150 \mathrm{rpm}\end{array}$ & $\begin{array}{l}\text { (L): } 15^{\circ} \mathrm{C}: 31.0 \mathrm{mg} \mathrm{g}^{-1} ; 25^{\circ} \mathrm{C}: \\
57.5 \mathrm{mg} \mathrm{g}^{-1} ; 35^{\circ} \mathrm{C}: 35.2 \mathrm{mg} \mathrm{g}^{-1}\end{array}$ & (Özer et al. 2005) \\
\hline C. albida $(\mathrm{M})$ & $\mathrm{Cr}(\mathrm{VI})$ & $\begin{array}{l}C_{\mathrm{S}} 0.2-10 \mathrm{~g} \mathrm{~L}^{-1}, \mathrm{pH} 0.5-12, C_{0} \\
20-154 \mathrm{mg} \mathrm{L}^{-1}, 25^{\circ} \mathrm{C}, 24 \mathrm{~h}, \\
200 \mathrm{rpm}\end{array}$ & $\begin{array}{l}q 47.1 \mathrm{mg} \mathrm{g}^{-1}\left(2 \mathrm{~g} \mathrm{~L}^{-1}, 25^{\circ} \mathrm{C}, \mathrm{pH} 0.5, C_{0}\right. \\
\left.\quad 154 \mathrm{mg} \mathrm{L}^{-1}\right)\end{array}$ & (Deng et al. 2009) \\
\hline Cladophora sp. (F) & $\begin{array}{l}\mathrm{Cr}(\mathrm{VI}) \\
\text { mala- } \\
\text { chite } \\
\text { green }\end{array}$ & $\begin{array}{l}C_{\mathrm{S}} 0.2-2 \mathrm{~g} \mathrm{~L}^{-1}, C_{0} 50-250 \mathrm{mg} \mathrm{L}^{-1} \\
\quad \text { pH } 2-10,120 \mathrm{rpm}\end{array}$ & $\begin{array}{l}\text { (L): } 100 \mathrm{mg} \mathrm{g}^{-1}(\mathrm{Cr}(\mathrm{VI}) ; \mathrm{pH} 2) ; \\
\left.143 \mathrm{mg} \mathrm{g}^{-1} \text { (malachite green, } \mathrm{pH} 7\right)\end{array}$ & $\begin{array}{l}\text { (Rangabhashiyam and } \\
\text { Balasubramanian } \\
\text { 2018) }\end{array}$ \\
\hline C. glomerata $(\mathrm{F})$ & $\mathrm{Cr}(\mathrm{III})$ & $\begin{array}{l}C_{\mathrm{S}} 1 \mathrm{~g} \mathrm{~L}^{-1}, C_{0} 25-400 \mathrm{mg} \mathrm{L}^{-1}, \mathrm{pH} \\
5,3 \mathrm{~h}, 20^{\circ} \mathrm{C}, 150 \mathrm{rpm}\end{array}$ & (L): $107 \mathrm{mg} \mathrm{g}^{-1}$ & $\begin{array}{l}\text { (Godlewska et al. } \\
\text { 2018) }\end{array}$ \\
\hline C. hutchinsiae (M) & $\mathrm{Se}(\mathrm{IV})$ & $\begin{array}{l}C_{\mathrm{S}} 1-20 \mathrm{~g} \mathrm{~L}^{-1}, C_{0} 10-400 \mathrm{mg} \mathrm{L}^{-1} \\
\text { pH } 2-8,5-120 \mathrm{~min}, 20-50{ }^{\circ} \mathrm{C} \\
120 \mathrm{rpm}\end{array}$ & 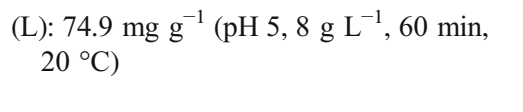 & (Tuzen and Sari 2010) \\
\hline C. crispata $(\mathrm{F})$ & $\mathrm{Zn}(\mathrm{II})$ & $\begin{array}{l}C_{\mathrm{S}} 1 \mathrm{~g} \mathrm{~L}^{-1}, C_{0} 10-100 \mathrm{mg} \mathrm{L}^{-1}, \mathrm{pH} \\
\quad 5,2 \mathrm{~h}, 25^{\circ} \mathrm{C}, 150 \mathrm{rpm}\end{array}$ & (L): $31.1 \mathrm{mg} \mathrm{g}^{-1}$ & (Özer et al. 2000) \\
\hline $\begin{array}{l}\text { Cladophora sp. immobilized } \\
\text { in alginate beads and } \\
\text { silica gel }\end{array}$ & $\operatorname{Hg}(\mathrm{II})$ & $\begin{array}{l}C_{\mathrm{S}} 10 \mathrm{~g} \mathrm{~L}^{-1}, C_{0} 1-100 \mathrm{mg} \mathrm{L}^{-1}, \mathrm{pH} \\
\quad 5,1 \mathrm{~h}, 25^{\circ} \mathrm{C}\end{array}$ & $\begin{array}{l}\text { (L): Alginate beads: } 172.4 \mathrm{mg} \mathrm{g}^{-1} \text {; } \\
\text { (L): Silica gel: } 121.9 \mathrm{mg} \mathrm{g}^{-1}\end{array}$ & (Mokone et al. 2018) \\
\hline C. hutchinsiae (M) & $\mathrm{U}(\mathrm{VI})$ & $\begin{array}{l}C_{\mathrm{S}} 12 \mathrm{~g} \mathrm{~L}^{-1}, C_{0} 10-400 \mathrm{mg} \mathrm{L}^{-1}, \mathrm{pH} \\
\quad 5,1 \mathrm{~h}, 20^{\circ} \mathrm{C}, 120 \mathrm{rpm}\end{array}$ & (L): $152 \mathrm{mg} \mathrm{g}^{-1}$ & (Bağda et al. 2017) \\
\hline
\end{tabular}

$C_{S}$ content of the biomass in the solution $\left(\mathrm{g} \mathrm{L}^{-1}\right), C_{0}$ initial concentration of metal ions in the solution, $(L)$ maximum biosorption capacity (mg $\mathrm{g}^{-1}$ ) determined from Langmuir equation

as a biosorbent for wastewater treatment, but also as a valuable soil amendment.

Most of the experiments concerning biosorption of pollutants by Cladophora species were performed on a laboratory scale. There is still a need to examine the industrial application of biosorption and algal biosorbents using continuous flow studies.

\section{Cladophora species as a source of energy}

Algae are also proposed as a renewable source of energy due to their advantages such as fast growth rate and less requirement of cultivation area (without competition with the food production sector for cultivation space) (Chaiwong et al. 2012; Yuvarani et al. 2017). Therefore,
Cladophora biomass can also find a utilization for the production of biofuels. Nowadays, marine and freshwater macroalgae constitute the third generation of biofuels (Behera et al. 2015; Norouzi et al. 2016). The main algal biomass conversion processes for the production of biofuels are as follows: biochemical conversion (anaerobic digestion for the production of biogas; fermentationethanol; photobiological hydrogen production-hydrogen), thermochemical conversion (pyrolysis for the production of bio-oil, syngas, biochar; gasification-syngas; liquefaction-bio-oil; combustion-electricity), chemical conversion (transesterification for the production of biodiesel) (Behera et al. 2015; Michalak 2018). Due to high water content in macroalgae, hydrothermal processes are the most suitable and ecofriendly for the production of 
biofuels. Algal biomass can be used for the production of biogas or bioethanol. There are some examples in the literature, suggesting that this solution has advantages such as waste management and avoidance of natural resource extraction (Dorella et al. 2018). The biomass of Cladophora sp. can be processed alone or with other waste biomass. Dorella et al. (2018) proposed the production of biogas from Cladophora species mixed with wheat straw. Jachniak et al. (2018) produced biogas from Cladophora collected from the Baltic Sea but the amount of the obtained methane was not impressive- 0.198 $\mathrm{L} \mathrm{g}^{-1}$. The obtained biogas contained $73.3 \%$ of methane and $12.8 \%$ of carbon dioxide.

Macroalgae due to high content of carbohydrates constitute a suitable material for ethanol production, but their utilization depends on the material resources, which are different in each country (Vo Thanh Trung et al. 2013). Boonprab et al. (2018) proposed to use freshwater C. glomerata as a polysaccharide resource (cellulose) for bioethanol processing. Algae produce glucose - a substrate for microorganism (fungus Monascus sp. NP1) to convert into ethanol. In this work, it was shown that during fermentation in algal extract that lasted for 12 days, the mold produced twofold more ethanol than the yeastSaccharomyces cerevisiae TISTR 5049. Vo Thanh Trung et al. (2013) showed that the biomass of marine Cladophora sp. including C. prolifera, C. socialis, and C. crupila was easily hydrolyzed using sulfuric acid and enzymatic hydrolysis with cellulose. The content of total sugar was comparable for these two methods and the obtained solution was easily fermented by $S$. cerevisiae at $30{ }^{\circ} \mathrm{C}$ for $72 \mathrm{~h}$.

Sharmila and Jeyanthi (2012) used the biomass of freshwater C. vagabunda for the production of biodiesel. For the extraction of oil, the mixture chloroform-methanol and isopropanol was used. The oil yield was $8.1 \%$ and $4.5 \%$, respectively. Methanol and base as catalyst were used for transesterification. Chloroform-methanol solvent system produced more biodiesel $(3.3 \mathrm{~mL}$ per $10 \mathrm{~g}$ of dry algae) than isopropanol system $(2.6 \mathrm{~mL}$ per $10 \mathrm{~g})$. Yuvarani et al. (2017) also found that the extraction of oil from freshwater C. glomerata using Soxhlet extraction was the most efficient (18\%), when the methanol-chloroform solvent mixture was used at $65^{\circ} \mathrm{C}$ for $3.5 \mathrm{~h}$. The authors examined also other solvents such as hexane-isopropanol (14.9\%), hexane $(11.8 \%)$, isopropanol $(9.8 \%)$, toluene $(9.0 \%)$, methanol $(8.6 \%)$, and chloroform (7.6\%). What is important, the content of sulfur in algal oil is low, which makes it environment friendly with less corrosion and pollution.

In the case of $C$. glomerata, the following process can be used: hydrothermal liquefaction for the production of biocrude oil and biochar (Neveux et al. 2014; Parsa et al. 2018); hydrothermal gasification for the production of hydrogen, bio-oil, and hydrochar, as a solid residue (Safari et al. 2016); pyrolysis for the production of hydrogen-rich gas, bio-oil, and biochar (Chaiwong et al. 2012; Plis et al. 2015; Norouzi et al. 2016; Gao et al. 2017). Solid biochar produced during pyrolysis of C. glomerata can be used as a catalyst for enhancement of hydrogen production and upgrade the bio-oil (Norouzi et al. 2016).

\section{Other applications}

There are several high-tech applications of the Cladophora biomass, especially its constituent-cellulose (Mihranyan 2011). Cellulose from Cladophora species found application as a substrate material in filter membranes (e.g., filter paper, dialyzer membranes). Cladophora cellulose can be also used as a drug carrier. Due to high surface area of Cladophora cellulose powder, it is a suitable substrate for the manufacturing of highly porous composite paper materials (Mihranyan et al. 2008; Mihranyan 2011). Mihranyan et al. (2008) produced a conducting paper material characterized by a high specific surface area through polymerization of pyrrole in the presence of $\mathrm{FeCl}_{3}$ on a cellulose substrate derived from Cladophora sp. Moreover, this material is light, compact, mechanically stable, and moldable into paper sheets. Therefore, separation or electrochemically controlled ion exchange devices and sensors can be applied. Cellulose extracted from Cladophora can be also used for the fabrication of a composite material together with polyaniline. The presence of a nanolayer of polyaniline on the cellulose fibers preserves its high surface area and thus good sorption properties. This composite was proposed for the remediation of toxic hexavalent chromium - very toxic $\mathrm{Cr}(\mathrm{VI})$ ions are reduced to less toxic Cr(III) ions (Camacho et al. 2013).

The biochar from marine C. glomerata characterized with high thermal stability and macro-/microporous structure can be used as a renewable, low-cost, and environmentally friendly electrode material for Li-ion batteries, which are commonly used in energy storage devices (Salimi et al. 2017). NMR spectroscopy of lipidic extract of marine C. rupestris showed that it contains also polyhydroxybutyrate, which is a natural biodegradable and biocompatible polymer that has a potential to be used in many biotechnological applications such as compostable plastic or medical devices (Stabili et al. 2014).

\section{Conclusions}

Based on the ecological characteristics of Cladophora highlighted in this study and on the previous knowledge about the habitat tolerance of this genera, we predict its consolidation in aquatic communities potentially changing their structure and dynamics. This analysis confirmed the described 
seasonality of occurrence of filamentous green algae. Growth patterns for the common filamentous algae Cladophora indicate the occurrence of both an early spring species and typically summer species in inland ecosystems. Thus, the algae biomass harvesting for industrial purposes will be characterized by seasonality. Cladophora glomerata has a wide tolerance range for temperature changes and has low light requirements. It is a dominant species in filamentous algae communities and develops in different habitat conditions than other Cladophora taxa. This species prefers fertile waters and creates large patches in the surface water. It has the features of pioneer species and is resistant to stress factors. The presence of different species of mats leads to changes in the abiotic elements of the habitat of the studied aquatic ecosystems. Cladophora species have a label as ecological engineers which suggests diverse opportunities for technological applications. This is possible due to their abundance and the content of bioactive compounds. Cladophora species serve as a novel source of natural agents for pharmaceutical, nutraceutical, food, and cosmetic industries. Macroalgae show also very good biosorption and bioaccumulation properties; this is why they are recommended for the removal of metal ions from contaminated areas.

Acknowledgments The authors thank M. Pikosz and E. Treska for the help and technical assistance in the laboratory.

Funding I.M. was funded by a grant entitled: "The effect of bioactive algae enriched by biosorption in the certain minerals such as $\mathrm{Cr}$ (III), $\mathrm{Mg}$ (II) and $\mathrm{Mn}$ (II) on the status of glucose in the course of metabolic syndrome horses. Evaluation in vitro and in vivo" (No 2015/18/E/NZ9/ 00607) and "Eco-friendly technologies for the management of seaweed biomass for products useful for sustainable agriculture and biosorbents used for the removal of heavy metal ions from the environment" (No 2019/33/B/NZ9/01844) from the National Science Centre in Poland. B.M. was funded by grants entitled: "Physico-chemical and biological causes of ecological dominance of filamentous green algae in freshwater ecosystems" (No 2014/13/B/NZ8/04690) and "Biological and physicochemical variability in seasonal intensification of growth of macroalgal biomass in inland waters from different biogeographical zones" (No 2018/31/B/NZ8/00280) from the National Science Centre in Poland.

\section{Compliance with ethical standards}

Conflict of interest The authors declare that they have no conflict of interest.

Open Access This article is licensed under a Creative Commons Attribution 4.0 International License, which permits use, sharing, adaptation, distribution and reproduction in any medium or format, as long as you give appropriate credit to the original author(s) and the source, provide a link to the Creative Commons licence, and indicate if changes were made. The images or other third party material in this article are included in the article's Creative Commons licence, unless indicated otherwise in a credit line to the material. If material is not included in the article's Creative Commons licence and your intended use is not permitted by statutory regulation or exceeds the permitted use, you will need to obtain permission directly from the copyright holder. To view a copy of this licence, visit http://creativecommons.org/licenses/by/4.0/.

\section{References}

Akin HK, Ünlü E (2013) Cadmium accumulation by green algae Cladophora glomerata (L.) Kütz. (Chlorophyta) in presence of Nile tilapia Oreochromis niloticus (L.). Toxicol Environ Chem 95: $1565-1571$

Akköz C, Arslan D, Ünver A, Özcan MM, Yilmaz B (2011) Chemical composition, total phenolic and mineral contents of Enteromorpha intestinalis (L.) Kütz. and Cladophora glomerata (L.) Kütz. seaweeds. J Food Biochem 35:513-523

Aksu Z, Kutsal T (1998) Determination of kinetic parameters in the biosorption of copper(II) on Cladophora sp., in a packed bed column reactor. Process Biochem 33:7-13

Aksu Z, Özer D, Ekiz HI, Kutsal T, Çaglar A (1996) Investigation of biosorption of chromium(VI) on Cladophora crispata in two-staged batch reactor. Environ Technol 17:215-220

Aksu Z, Özer D, Özer A, Kutsal T, Çaglar A (1998) Investigation of the column performance of cadmium(II) biosorption by Cladophora crispata floes in a packed bed. Sep Sci Technol 33:668-682

Amornlerdpison D, Mengumphan K, Thumvijit S, Peerapornpisal Y (2011) Antioxidant and anti-inflammatory activities of freshwater macroalga, Cladophora glomerata Kützing. Thai J Agric Sci 44: 283-291

Amro A, Abhary M (2019) Removal of lead and cadmium ions from water using Cladophora biomass. Polish J Environ Stud 28:35893596

Andersen RA (2005) Algal culturing techniques. Elsevier Academic Press, Burlington, p 596

Anh NTN, Hai TN, Hien TTT (2018) Effects of partial replacement of fishmeal protein with green seaweed (Cladophora spp.) protein in practical diets for the black tiger shrimp (Penaeus monodon) postlarvae. J Appl Phycol 30:2649-2658

Appler HN, Jauncey K (1983) The utilization of a filamentous green alga (Cladophora glomerata (L) Kutzin) as a protein source in pelleted feeds for Sarotherodon (Tilapia) niloticus fingerlings. Aquaculture 30:21-30

Bačkorová M, Maslaňáková I, Bačkor M (2016) Copper uptake and copper-induced physiological changes in the marine alga Cladophora prolifera (Roth.) Kütz. (Chlorophyta, Ulvophyceae). Rev Bras Bot 39:447-452

Bağda E, Tuzen M, Sarı A (2017) Equilibrium, thermodynamic and kinetic investigations for biosorption of uranium with green algae (Cladophora hutchinsiae). J Environ Radioact 175-176:7-14

Barinova S, Kukhaleishvili L, Nevo E, Janelidze Z (2011) Diversity and ecology of algae in the Algeti National Park as a part of the Georgian system of protected areas. Turk J Bot 35:729-774

Behera S, Singh R, Arora R, Kumar Sharma N, Shukla M, Kumar S (2015) Scope of algae as third generation biofuels. Front Bioeng Biotechnol 2:90

Bird MI, Wurster CM, de Paula Silva PH, Bass AM, de Nys R (2011) Algal biochar - production and properties. Bioresour Technol 102: 1886-1891

Blinn DW, Shannon JP, Benenati PL, Wilson KP (1998) Algal ecology in tailwater stream communities: the Colorado River below Glen Canyon Dam, Arizona. J Phycol 34:734-740

Boedeker C, Immers A (2009) No more lake balls (Aegagropila linnaei Kützing, Cladophorophyceae, Chlorophyta) in the Netherlands? Aquat Ecol 43:891-902

Boedeker C, Sviridenko BF (2012) Cladophora koktschetavensis from Kazakhstan is a synonym of Aegagropila linnaei (Cladophorales, Chlorophyta) and fills the gap in the disjunct distribution of a widespread genotype. Aquat Bot 101:64-68

Boedeker C, Eggert A, Immers A, Wakana I (2010) Biogeography of Aegagropila linnaei (Cladophorophyceae, Chlorophyta): a 
widespread freshwater alga with low effective dispersal potential shows a glacial imprint in its distribution. J Biogeogr 37:1491-1503

Boedeker C, Kelly CJ, Star W, Leliaert F (2012) Molecular phylogeny and taxonomy of the Aegagropila clade (Cladophorales, Ulvophyceae), including the description of Aegagropilopsis gen. nov. and Pseudocladophora gen. nov. J Phycol 48:808-825

Bojorge-García M, Carmona J, Beltrán Y, Cartajena M (2010) Temporal and spatial distribution of macroalgal communities of mountain streams in Valle de Bravo Basin, central Mexico. Hydrobiologia 641:159-169

Boonprab K, Matsui K, Kataoka N (2018) Preliminary study on bioethanol from fresh water algae, Cladophora glomerata (Sarai Kai) by the fungus, Monascus sp. NP1. J Appl Phycol 30:137-141

Bourebaba L, Michalak I, Röcken M, Marycz K (2019) Cladophora glomerata methanolic extract decreases oxidative stress and improves viability and mitochondrial potential in equine adipose derived mesenchymal stem cells (ASCs). Biomed Pharmacother 111: 6-18

Camacho DH, Gerongay SPC, Macalinao JPC (2013) Cladophora cellulose-polyaniline composite for remediation of toxic chromium (VI). Cellul Chem Technol 47:125-132

Cambra J, Aboal M (1992) Filamentous green algae of Spain: distribution and ecology. Limnetica 8:213-220

Cambridge ML, Breeman AM, van den Kraak S, Hoek C (1987) Temperature responses of tropical to warm temperate Cladophora species in relation to their distribution in the North Atlantic Ocean. Helgol Meeresunters 41:329-354

Cao D-J, Xie P-P, Deng J-W, Zhang H-M, Ma R-X, Liu C, Liu R-J, Liang Y-G, Li H, Shi X-D (2015) Effects of $\mathrm{Cu}^{2+}$ and $\mathrm{Zn}^{2+}$ on growth and physiological characteristics of green algae, Cladophora. Environ Sci Pollut Res 22:16535-16541

Cavallo A, Giangrande A, Accogli R, Marchiori S (2006) A test on the use of Cladophora prolifera (Roth.) Kutz. (Chlorophyta, Cladophorales) as effective fertilizer for agricultural use. Thalassia Salentina 29:101-106

Chaiwong K, Kiatsiriroat T, Vorayos N, Thararax C (2012) Biochar production from freshwater algae by slow pyrolysis. Maejo Int $\mathrm{J}$ Sci Technol 6:186-195

Chapin FS (1991) Integrated responses of plants to stress: a centralized system of physiological responses. Bioscience 41:29-36

Chmielewská E, Medved J (2001) Bioaccumulation of heavy metals by green algae Cladophora glomerata in a refinery sewage lagoon. Croat Chem Acta 74:135-145

Choo KS, Snoeijs P, Pedersén M (2002) Uptake of inorganic carbon by Cladophora glomerata (Chlorophyta) from the Baltic Sea. J Phycol 38:493-502

Chudyba H (1965) Cladophora glomerata i glony towarzyszace w rzece Skawie. Rozmieszczenie i warunki występowania (in Polish). $\mathrm{PhD}$ Thesis, Kated Bot Wyższej Szk Rol w Olsztynie, Poland

Comte K, Cazaubon A (2002) Structural variations of epiphytic diatom communities on three macrophytes in a regulated river (Durance), in south-east of France. Ann Limnol 38:297-305

Coppejans E, Leliaert F, Verbruggen H (2005) Green algae. Chlorophyceae. Guide to the seaweeds of KwaZulu-Natal. Scr Bot Belgica 33:38-93

Cruz-Suárez LE, León A, Peña-Rodríguez A, Rodríguez-Peña G, Moll B, Ricque-Marie D (2010) Shrimp/Ulva co-culture: a sustainable alternative to diminish the need for artificial feed and improve shrimp quality. Aquaculture 301:64-68

Deng L, Su Y, Su H, Wang X, Zhu X (2006) Biosorption of copper (II) and lead (II) from aqueous solutions by nonliving green algae Cladophora fascicularis: equilibrium, kinetics and environmental effects. Adsorption 12:267-277

Deng L, Zhu X, Wang X, Su Y, Su H (2007) Biosorption of copper (II) from aqueous solutions by green alga Cladophora fascicularis. Biodegradation 18:393-402
Deng L, Zhu X, Su Y, Su H, Wang X (2008) Biosorption and desorption of $\mathrm{Cd}^{2+}$ from wastewater by dehydrated shreds of Cladophora fascicularis. Chin J Oceanol Limnol 26:45-49

Deng L, Zhang Y, Qin J, Wang X, Zhu X (2009) Biosorption of Cr(VI) from aqueous solutions by nonliving green algae Cladophora albida. Miner Eng 22:372-377

Dodds WK, Gudder DA (1992) The ecology of Cladophora. J Phycol 28 : 415-427

Dorella M, Romagnoli F, Gruduls A, Collotta M, Tomasoni G (2018) Design of a biogas plant fed with Cladophora sp. algae and wheat straw. Energy Proced 147:458-466

Douma M, El Kerroumi A, Manaut N, Harkousse O, Najib Al Feddy M, Ouahmane L (2017) First assessment of the anti-phytopathogenic activity of two Cladophora species against Fusarium oxysporum $\mathrm{f}$. sp. albedinis. Res J Pharm Biol Chem Sci 8:262-266

Ebadi AG, Hisoriev H (2017) The prevalence of heavy metals in Cladophora glomerata L. from Farahabad Region of Caspian Sea-Iran. Toxicol Environ Chem 99:883-891

Ek R, Gustafsson C, Nutt A, Iversen T, Nyström C (1998) Cellulose powder from Cladophora sp. algae. J Mol Recognit 11:263-265

Elenkov I, Georgieva T, Hadjieva P, Dimitrova-Konaklieva S, Popov S (1995) Terpenoids and sterols in Cladophora vagabunda. Phytochemistry 38:457-459

Elenkov I, Stefanov K, Alexandrova M, Dimitrova-Konaklieva S, Popov S (1996a) Lipid composition of some Bulgarian Cladophora species. Bot Mar 39:79-82

Elenkov I, Stefanov K, Dimitrova-Konaklieva S, Popov S (1996b) Effect of salinity on lipid composition of Cladophora vagabunda. Phytochemistry 42:39-44

Eriksson BK, Johansson G (2005) Effects of sedimentation on macroalgae: species-specific responses are related to reproductive traits. Oecologia 143:438-448

Fabrowska J, Łęska B, Schroeder G (2015) Freshwater Cladophora glomerata as a new potential cosmetic raw material. Chemik 69: 491-497

Fabrowska J, Kapuścińska A, Łęska B, Feliksik-Skrobich K, Nowak I (2017) In vivo studies and stability study of Cladophora glomerata extract as a cosmetic active ingredient. Acta Pol Pharm Drug Res 74: 633-641

Fabrowska J, Messyasz B, Pankiewicz R, Wilińska P, Łęska B (2018) Seasonal differences in the content of phenols and pigments in thalli of freshwater Cladophora glomerata and its habitat. Water Res 135: 66-74

Fairchild GW, Sherman JW, Acker FW (1989) Effects of nutrient (N, P, C) enrichment, grazing and depth upon littoral periphyton of a softwater lake. Hydrobiologia 173:69-83

Gao W, Chen K, Zeng J, Xu J, Wang B (2017) Thermal pyrolysis characteristics of macroalgae Cladophora glomerata. Bioresour Technol 243:212-217

Giangrande A, Cavallo A, Pierri C (2007) Ammonium uptake of Cladophora prolifera (Chlorophyta, Cladophorales) a candidate species for bioremediation of aquaculture wastes. Thalassia Salentina 30:107-116

Godlewska K, Marycz K, Michalak I (2018) Freshwater green macroalgae as a biosorbent of $\mathrm{Cr}$ (III) ions. Open Chem 16:689-701

Goodman KM, Hay ME (2013) Activated chemical defenses suppress herbivory on freshwater red algae. Oecologia 171:921-933

Guillard RRL, Lorenzen CJ (1972) Yellow-green algae with chlorophyllide $c$. J Phycol 8:10-14

Guiry M, Guiry G (2020) AlgaeBase. World-wide electronic publication. Natl Univ Ireland, Galway http//www.algaebase.org (accessed on 31 January 2020)

Hanyuda T, Wakana I, Arai S, Miyaji K, Watano Y, Ueda K (2002) Phylogenetic relationships within Cladophorales (Ulvophyceae, Chlorophyta) inferred from 18s rRNA gene sequences, with special reference to Aegagropila linnaei. J Phycol 38:564-571 
Harrison SSC, Hildrew AG (2001) Epilithic communities and habitat heterogeneity in a lake littoral. J Anim Ecol 70:692-707

Heiba HI, Al-Easa HS, Rizk AFM (1997) Fatty acid composition of twelve algae from the coastal zones of Qatar. Plant Foods Hum Nutr 51:27-34

Higgins SN, Howell ET, Hecky RE, Guildford SJ, Smith RE (2005) The wall of green: the status of Cladophora glomerata on the northern shores of Lake Erie's eastern basin, 1995-2002. J Great Lakes Res 31:547-563

Higgins SN, Hecky RE, Guildford SJ (2006) Environmental controls of Cladophora growth dynamics in eastern Lake Erie: application of the Cladophora growth model (CGM). J Great Lakes Res 32:629644

Higgins SN, Malkin SY, Todd Howell E, Guildford SJ, Campbell L, Hiriart-Baer V, Hecky RE (2008) An ecological review of Cladophora glomerata (Chlorophyta) in the Laurentian Great Lakes. J Phycol 44:839-854

Hoffmann JP, Graham LE (1984) Effects of selected physicochemical factors on growth and zoosporogenesis of Cladophora glomerata (Chlorophyta). J Phycol 20:1-7

Horincar VB, Parfene G, Tyagi AK, Gottardi D, Dinică R, Guerzoni ME, Bahrim G (2014) Extraction and characterization of volatile compounds and fatty acids from red and green macroalgae from the Romanian Black Sea in order to obtain valuable bioadditives and biopreservatives. J Appl Phycol 26:551-559

Jachniak E, Chmura J, Kuglarz M, Wiktor J (2018) The opportunities for obtaining of the biogas on methane fermentation from marine algae biomass and water plant biomass. BIO Web Conf 10:01007

Jafari N, Senobari Z (2012) Removal of Pb (II) ions from aqueous solutions by Cladophora rivularis (Linnaeus) Hoek. Sci World J 2012: 793606-793606

Jasrotia S, Kansal A, Kishore VVN (2014) Arsenic phyco-remediation by Cladophora algae and measurement of arsenic speciation and location of active absorption site using electron microscopy. Microchem J 114:197-202

Ji L, Xie S, Feng J, Li Y, Chen L (2012) Heavy metal uptake capacities by the common freshwater green alga Cladophora fracta. J Appl Phycol 24:979-983

Johansson C (1982) Attached algal vegetation in running waters of Jämtland, Sweden. Acta Phytogeographica Suecica, 71. Uppsala

Johnson M, Shivkumar S, Berlowitz-Tarrant L (1996) Structure and properties of filamentous green algae. Mater Sci Eng B 38:103-108

Jones HG (1978) How plants respond to stress. Nature 271:610

Kamenarska Z, Stefanov K, Dimitrova-Konaklieva S, Najdenski H, Tsvetkova I, Popov S (2004) Chemical composition and biological activity of the brackish-water green alga Cladophora rivularis (L.) Hoek. Bot Mar 47:215-221

Karan T, Erenler R (2018) Fatty acid constituents and anticancer activity of Cladophora fracta (OF Müller ex Vahl) Kützing. Trop J Pharm Res 17:1977-1982

Kaur G, Asthir B (2015) Proline: a key player in plant abiotic stress tolerance. Biol Plant 59:609-619

Kelly M, King L (2007) Freshwater macroalgae of Britain and Ireland. Macroalgae ID Guide North-South-Share Training course, Derrygonelly, Co Fermanagh 24-26th April 2007, Trial version

Khanum A (1982) An ecological study of freshwater algal mats. Bot Bull Acad Sin 23:89-104

Khuantrairong T, Traichaiyaporn S (2011) The nutritional value of edible freshwater alga Cladophora sp. (Chlorophyta) grown under different phosphorus concentrations. Int J Agric Biol 13:297-300

Kiirikki M, Lehvo A (1997) Life strategies of filamentous algae in the northern Baltic proper. Sarsia 82:259-267

Kornaś J, Pancer E, Brzyski B (1960) Studies on sea - bottom vegetation in the Bay of Gdańsk off Rewa. Fragm Flor Geobot 6:3-92

Lamai C, Kruatrachue M, Pokethitiyook P, Upathamb ES, Soonthornsarathoola V (2005) Toxicity and accumulation of lead and cadmium in the filamentous green alga Cladophora fracta (O.F. Muller ex Vahl) Kutzing: a laboratory study. SciAsia 31:121

Laungsuwon R, Chulalaksananukul W (2013) Antioxidant and anticancer activities of freshwater green algae, Cladophora glomerata and Microspora floccosa, from Nan River in northern Thailand. J Sci Technol 7:181-188

Laungsuwon R, Chulalaksananukul W (2014) Chemical composition and antibacterial activity of extracts from freshwater green algae, Cladophora glomerata Kützing and Microspora floccosa (Vaucher) Thuret. J BioSci Biotech 3:211-218

Lee R (2008) Phycology, 4th edn. Cambridge Univ Press, New York, pp $1-645$

Lee YC, Chang SP (2011) The biosorption of heavy metals from aqueous solution by Spirogyra and Cladophora filamentous macroalgae. Bioresour Technol 102:5297-5304

Lezcano V, Fernández C, Parodi ER, Morelli S (2018) Antitumor and antioxidant activity of the freshwater macroalga Cladophora surera. J Appl Phycol 30:2913-2921

Lüning K, Kadel P, Pang S (2008) Control of reproduction rhythmicity by environmental and endogenous signals in Ulva pseudocurvata (Chlorophyta). J Phycol 44:866-873

Mahadik BB, Jadhav MJ (2015) Antibacterial and antifungal activities of green alga Cladophora crispata. Indian J Appl Res 5:37-39

Malkin SY, Dove A, Depew D, Smith RE, Guildford SJ, Hecky RE (2010) Spatiotemporal patterns of water quality in Lake Ontario and their implications for nuisance growth of Cladophora. J Great Lakes Res 36:477-489

Marycz K, Michalak I, Kocherova I, Maredziak M, Weiss C (2017) The Cladophora glomerata enriched by biosorption process in $\mathrm{Cr}(\mathrm{III})$ improves viability, and reduces oxidative stress and apoptosis in equine metabolic syndrome derived adipose mesenchymal stromal stem cells (ASCs) and their extracellular vesicles (MV's). Mar Drugs 15:385

Mathiesen H, Mathiesen L (1992) Floristic aspects of the coastal inlet Inre Verkviken, northern Aland. In: Wallentinus I, Snoeijs P (eds) Phycological studies of Nordic coastal waters. Acta Phytogeog Suecica 78:101-111

Messyasz B, Kuczyńska-Kippen N (2006) Periphytic algal communities: a comparison of Typha angustifolia L. and Chara tomentosa L. beds in three shallow lakes (West Poland). Polish J Ecol 54:15-27

Messyasz B, Pikosz M, Rybak A, Łepkowska K (2012) Epiphytic diatom community and calcium carbonate crystals characteristics on the surface of freshwater Ulva thalli. Teka Kom Ochr Kszt Srod Przyr 9:96-106

Messyasz B, Pikosz M, Schroeder G, Łęska B, Fabrowska J (2015a) Identification and ecology of macroalgae species existing in Poland. In: Kim SK, Chojnacka K (eds) Marine algae extracts: processes, products, and applications. Wiley-VCH, Weinheim, pp 1540

Messyasz B, Łęska B, Fabrowska J, Pikosz M, Rój E, Cieślak A, Schroeder G (2015b) Biomass of freshwater Cladophora as a raw material for agriculture and the cosmetic industry. Open Chem 13: $1108-1118$

Messyasz B, Łęska B, Fabrowska J, Pikosz M, Rój E, Cieślak A, Schroeder G (2015c) Effects of organic compounds on the macroalgae culture of Aegagropila linnaei. Open Chem 13:10401044

Messyasz B, Pikosz M, Treska E (2018a) Biology of freshwater macroalgae and their distribution. In: Kim SK, Chojnacka K (eds) Algae biomass: characteristics and applications. Wiley-VCH, Weinheim, pp 17-31

Messyasz B, Michalak I, Łęska B, Schroeder G, Górka B, Korzeniowska K, Lipok J, Wieczorek P, Rój E, Wilk R, Dobrzyńska-Inger A, Górecki H, Chojnacka K (2018b) Valuable natural products from marine and freshwater macroalgae obtained from supercritical fluid extracts. J Appl Phycol 30:591-603 
Michalak I (2018) Experimental processing of seaweeds for biofuels. Wiley Interdiscip Rev Energy Environ 7:1-25

Michalak I, Chojnacka K, Dobrzański Z, Górecki H, Zielińska A, Korczyński M, Opaliński S (2011) Effect of macroalgae enriched with microelements on egg quality parameters and mineral content of eggs, eggshell, blood, feathers and droppings. J Anim Physiol Anim Nutr (Berl) 95:374-387

Michalak I, Tuhy Ł, Chojnacka K (2015) Seaweed extract by microwave assisted extraction as plant growth biostimulant. Open Chem 13: $1183-1195$

Michalak I, Chojnacka K, Dmytryk A, Wilk R, Gramza M, Rój E (2016a) Evaluation of supercritical extracts of algae as biostimulants of plant growth in field trials. Front Plant Sci 7:1-11

Michalak I, Górka B, Wieczorek PP, Rój E, Lipok J, Łęska B, Messyasz B, Wilk R, Schroeder G, Dobrzyńska-Inger A, Chojnacka K (2016b) Supercritical fluid extraction of algae enhances levels of biologically active compounds promoting plant growth. Eur J Phycol 51:243-252

Michalak I, Dmytryk A, Schroeder G, Chojnacka K (2017a) The application of homogenate and filtrate from Baltic seaweeds in seedling growth tests. Appl Sci 7:1-19

Michalak I, Miller U, Tuhy Ł, Sówka I, Chojnacka K (2017b) Characterisation of biological properties of co-composted Baltic seaweeds in germination tests. Eng Life Sci 17:153-164

Michalak I, Wilk R, Chojnacka K (2017c) Bioconversion of Baltic seaweeds into organic compost. Waste Biomass Valoriz 8:1885-1895

Michalak I, Lewandowska S, Detyna J, Olsztyńska-Janus S, Bujak H, Pacholska P (2018a) The effect of macroalgal extracts and near infrared radiation on germination of soybean seedlings: preliminary research results. Open Chem 16:1066-1076

Michalak I, Mironiuk M, Marycz K (2018b) A comprehensive analysis of biosorption of metal ions by macroalgae using ICP-OES, SEMEDX and FTIR techniques. PLoS One 13:0205590

Michalak I, Baśladyńska S, Mokrzycki J, Rutkowski P (2019a) Biochar from a freshwater macroalga as a potential biosorbent for wastewater treatment. Water (Switzerland) 11:4-6

Michalak I, Lewandowska S, Niemczyk K, Detyna J, Bujak H, Arik P, Bartniczak A (2019b) Germination of soybean seeds exposed to the static/alternating magnetic field and algal extract. Eng Life Sci 19: 986-999

Mihranyan A (2011) Cellulose from Cladophorales green algae: from environmental problem to high-tech composite materials. J Appl Polym Sci 119:2449-2460

Mihranyan A, Nyholm L, Garcia Bennett AE, Strømme M (2008) A novel high specific surface area conducting paper material composed of polypyrrole and Cladophora cellulose. J Phys Chem B 112:12249-12255

Mohammed DY, Dwaish AS, Jawad ALM (2014) Anti-phytopathogenic activities of Cladophora glomerata extract against plant fungi. Baghdad Sci J 11:883-887

Mokone JG, Tutu H, Chimuka L, Cukrowska EM (2018) Optimization and characterization of Cladophora sp. alga immobilized in alginate beads and silica gel for the biosorption of mercury from aqueous solutions. Water Air Soil Pollut 229:215

Mpawenayo B, Mathooko JM (2005) The structure of diatom assemblages associated with Cladophora and sediments in a highland stream in Kenya. Hydrobiologia 544:55-67

Msuya FE, Neori A (2008) Effect of water aeration and nutrient load level on biomass yield, $\mathrm{N}$ uptake and protein content of the seaweed Ulva lactuca cultured in seawater tanks. J Appl Phycol 20:1021-1031

Munir M, Qureshi R, Bibi M, Khan AM (2019) Pharmaceutical aptitude of Cladophora: a comprehensive review. Algal Res 39:101476

Naw MWD, Win SS (2011) Morphology and nutritional values of green alga Cladophora from Kachin State. Univ Res J 4:99-111

Neveux N, Yuen AKL, Jazrawi C, Magnusson M, Haynes BS, Masters AF, Montoya A, Paul NA, Maschmeyer T, de Nys R (2014)
Biocrude yield and productivity from the hydrothermal liquefaction of marine and freshwater green macroalgae. Bioresour Technol 155: 334-341

Norouzi O, Jafarian S, Safari F, Tavasoli A, Nejati B (2016) Promotion of hydrogen-rich gas and phenolic-rich bio-oil production from green macroalgae Cladophora glomerata via pyrolysis over its bio-char. Bioresour Technol 219:643-651

Özer A, Özer D, Dursun G, Bulak S (1999) Cadmium(II) adsorption on Cladophora crispata in batch stirred reactors in series. Waste Manag 19:233-240

Özer D, Özer A, Dursun G (2000) Investigation of zinc (II) adsorption on Cladophora crispata in a two-staged reactor. J Chem Technol Biotechnol 75:410-416

Özer A, Özer D, Ekiz HI (2005) The equilibrium and kinetic modelling of the biosorption of copper(II) ions on Cladophora crispata. Adsorption 10:317-326

Ożgo M (2010) The role of small water bodies in the conservation of biodiversity (in Polish). Park Nar i Rezerwaty Przyr 29:117-124

Pankiewicz R, Łęska B, Messyasz B, Fabrowska J, Sołoducha M, Pikosz M (2016) First isolation of polysaccharidic ulvans from the cell walls of freshwater algae. Algal Res 19:348-354

Parker JE, Maberly SC (2000) Biological response to lake remediation by phosphate stripping: control of Cladophora. Freshw Biol 44:303309

Pärnoja M, Kotta J, Orav-Kotta H, Paalme T (2014) Comparisons of individual and community photosynthetic production indicate light limitation in the shallow water macroalgal communities of the Northern Baltic Sea. Mar Ecol 35:19-27

Parsa M, Jalilzadeh H, Pazoki M, Ghasemzadeh R, Abduli MA (2018) Hydrothermal liquefaction of Gracilaria gracilis and Cladophora glomerata macro-algae for biocrude production. Bioresour Technol 250:26-34

Pereira L (2016) Edible seaweeds of the world. Science Publishers, Boca Raton, pp 1-448

Pieczyńska E, Tarmanowska A (1996) Effect of decomposing filamentous algae on the growth of Elodea canadensis Mich. (a laboratory experiment). Aquat Bot 54:313-319

Pihl L, Svenson A, Moksnes PO, Wennhage H (1999) Distribution of green algal mats throughout shallow soft bottoms of the Swedish Skagerrak archipelago in relation to nutrient sources and wave exposure. J Sea Res 41:281-294

Pikosz M, Messyasz B (2015) Composition and seasonal changes in filamentous algae in floating mats. Oceanol Hydrobiol Stud 44: 273-281

Pikosz M, Messyasz B (2016) Characteristics of Cladophora and coexisting filamentous algae in relation to environmental factors in freshwater ecosystems in Poland. Oceanol Hydrobiol Stud 45:202215

Pikosz M, Messyasz B, Gąbka M (2017) Functional structure of algal mat (Cladophora glomerata) in a freshwater in western Poland. Ecol Indic 74:1-9

Pikosz M, Czerwik-Marcinkowska J, Messyasz B (2019) The effect of Cladophora glomerata exudates on the amino acid composition of Cladophora fracta and Rhizoclonium sp. Open Chem 17:313-324

Piotrowicz Z, Tabisz Ł, Łeska B (2019) Material balance for stepwise extraction of freshwater algae biomass with heavy metal sequestration. Ecol Chem Eng S 26:675-685

Pliński M, Florczyk I (1984) Analysis of the composition and vertical distribution of the macroalgal in western part of the Gulf of Gdańsk in 1979 and 1980. Oceanologia 19:101-115

Pliński M, Hindák F (2012) Zielenice - Chlorophyta: filamentous green algae. Wydaw Uniw Gdańskiego, Gdańsk, pp 1-189

Pliński M, Jóźwiak T (2004) The distribution of water vegetation on the Polish coast of the Baltic Sea in 1996-2000. Oceanol Hydrobiol Stud 33:29-40 
Plis A, Lasek J, Skawińska A, Zuwała J (2015) Thermochemical and kinetic analysis of the pyrolysis process in Cladophora glomerata algae. J Anal Appl Pyrol 115:166-174

Prazukin AV, Anufriieva EV, Shadrin NV (2018) Cladophora mats in a Crimean hypersaline lake: structure, dynamics, and inhabiting animals. J Oceanol Limnol 36:1930-1940

Promya J, Chitmanat C (2011) The effects of Spirulina platensis and Cladophora algae on the growth performance, meat quality and immunity stimulating capacity of the African Sharptooth catfish (Clarias gariepinus). Int J Agric Biol 13:77-82

Rangabhashiyam S, Balasubramanian P (2018) Biosorption of hexavalent chromium and malachite green from aqueous effluents, using Cladophora sp. Chem Ecol 34:371-390

Rani G (2007) Changes in protein profile and amino acids in Cladophora vagabunda (Chlorophyceae) in response to salinity stress. J Appl Phycol 19:803-807

Robertson-Andersson DV, Potgieter M, Hansen J, Bolton JJ, Troell M, Anderson RJ, Halling C, Probyn T (2008) Integrated seaweed cultivation on an abalone farm in South Africa. J Appl Phycol 20:579595

Rosińska B, Chojnacki JC, Klej K, Kowalewska M, Polońska J (2013) The ecological structure macrofauling community of the eastern shore of the Pomeranian Bay (southern Baltic Sea) in 2008 on the anthropogenic substrates. Inż Ekol 35:60-68

Ross ME, Davis K, McColl R, Stanley MS, Day JG, Semiãoa AJC (2018) Nitrogen uptake by the macro-algae Cladophora coelothrix and Cladophora parriaudii: influence on growth, nitrogen preference and biochemical composition. Algal Res 30:1-10

Safari F, Norouzi O, Tavasoli A (2016) Hydrothermal gasification of Cladophora glomerata macroalgae over its hydrochar as a catalyst for hydrogen-rich gas production. Bioresour Technol 222:232-241

Salimi P, Javadian S, Norouzi O, Gharibi H (2017) Turning an environmental problem into an opportunity: potential use of biochar derived from a harmful marine biomass named Cladophora glomerata as anode electrode for Li-ion batteries. Environ Sci Pollut Res 24: 27974-27984

Saunders LL, Kilham SS, Winfield Fairchild G, Verb R (2012) Effects of small-scale environmental variation on metaphyton condition and community composition. Freshw Biol 57:1884-1895

Scheffer M, Van Geest GJ, Zimmer K, Jeppesen E, Søndergaard M, Butler MG, Hanson MA, Declerck S, de Meester L, Persson L (2006) Small habitat size and isolation can promote species richness: second-order effects on biodiversity in shallow lakes and ponds. Oikos 112:227-231

Schiewer U (2008) Ecology of Baltic coastal waters. Springer, Berlin

Schroeder G, Messyasz B, Łęska B (2016) Identification of biologically active compounds and assessment of commercial properties of algal extracts as cosmetic ingredients. In: Chojnacka K, Michalak I (eds) innovative Bio-Products for Agriculture: Algal Extracts in Products for Humans, Animals and Plants. Nova Science Publishers, New York, pp 73-99

Sharmila S, Jeyanthi RL (2012) GC-MS analysis of esters of fatty acid present in biodiesel produced from Cladophora vagabunda. J Chem Pharm Res 4:4883-4887

Sheikh TZB, Yong CL, Lian MS (2009) In vitro antioxidant activity of the hexane and methanolic extracts of Sargassum baccularia and Cladophora patentiramea. J Appl Sci 9:2490-2493

Shelton AD, Miller MC (2002) Herbicide bioconcentration in Cladophora glomerata: Atrazine removal in a eutrophic agricultural river. Hydrobiologia 469:157-164

Siddique M, Faridi M (1977) The life history of Cladophora crispata (Roth) Ag. Pak J Bot 9:159-162

Silva P (1982) Thallobionta. In: Park SP (ed) Synopsis and classification of living organisms. McGraw-Hill, New York, pp 59-60
Škaloud P, Rindi F, Boedeker C, Leliaert F (2018) Chlorophyta: Ulvophyceae (Süßwasserflora von Mitteleuropa, Bd. 13: Chlorophyta: Ulvophyceae)., pp 1-288

Snoeijs P (1999) Marine and brackish waters. Acta Phytogeogr Suec 84: $187-212$

Sobhan R, Sternberg SPK (1999) Cadmium removal using Cladophora. J Environ Sci Health A 34:53-72

Soejima A, Yamazaki N, Nishino T, Wakana I (2009) Genetic variation and structure of the endangered freshwater benthic alga Marimo, Aegagropila linnaei (Ulvophyceae) in Japanese lakes. Aquat Ecol 43:359-370

Soltani S, Saadatmand S, Khavarinejad R, Nejadsattari T (2011) Antioxidant and antibacterial activities of Cladophora glomerata (L.) Kütz. in Caspian Sea Coast, Iran. Afr J Biotech 10:7684-7689

South R, Whittick A (1996) Introduction to phycology. Blackwell, Oxford, pp 1-341

Srimaroeng C, Ontawong A, Saowakon N, Vivithanaporn P, Pongchaidecha A, Amornlerdpison D, Soodvilai S, Chatsudthipong V (2015) Antidiabetic and renoprotective effects of Cladophora glomerata Kützing extract in experimental type 2 diabetic rats: a potential nutraceutical product for diabetic nephropathy. J Diabetes Res 2015:320167-320115

Stabili L, Acquaviva MI, Biandolino F, Cavallo RA, De Pascali SA, Fanizzi FP, Narracci M, Cecere E, Petrocelli A (2014) Biotechnological potential of the seaweed Cladophora rupestris (Chlorophyta, Cladophorales) lipidic extract. Nat Biotechnol 31: 436-444

Starmach K (1969) Hildenbrandia rivularis (Liebm.) I. Ag., Chamaesiphon fuscoviolaceus $\mathrm{n} \mathrm{sp}$. i glony towarzyszace w potoku Lubogoszcz w Beskidzie Wyspowym. Fragm Flor Geobot 15:487501

Starmach K (1972) Filamentous green algae: Ulotrichales, Ulvales, Prasiolales, Sphawroaleales, Cladophorales, Chaetophorales, Trentepohliales, Siphonales. Dichotomosiphonales. Flora słodkowodna Polski, PWN, Warszawa-Kraków

Sternberg SPK, Dorn RW (2002) Cadmium removal using Cladophora in batch, semi-batch and flow reactors. Bioresour Technol 81:249 255

Stewart TW, Lowe RL (2008) Benthic algae of Lake Erie (1865-2006): a review of assemblage composition, ecology, and causes and consequences of changing abundance. Ohio J Sci 108:82-94

Sundbäck K, McGlathery K (2005) Interaction between benethic macroand microalgae in the marine environment. Kristensen EJ, Kostka E, Haese RH Interact between macro- Microorg Mar sediments Am Geophys Union, Washington, DC

Titlyanov EA, Titlyanova TV, Li X, Kalita TL, Huang H (2015) Recent (2008-2012) seaweed flora of Hainan Island, South China Sea. Mar Biol Res 11:540-550

Titlyanov EA, Titlyanova TV, Tokeshi M, Li X (2019) Inventory and historical changes in the marine flora of Tomioka Peninsula (Amakusa Island), Japan. Diversity 11

Titlyanova T, Titlyanov E, Kalita TL (2014) Marine algal flora of Hainan Island: a comprehensive synthesis. Coast Ecosyst 1:28-53

Togashi T, Sasaki H, Yoshimura J (2014) A geometrical approach explains Lake Ball (Marimo) formations in the green alga, Aegagropila linnaei. Sci Rep 4:3761

Tolstoy A, Österlund K (2003) Alger vid Sveriges ÖstersjÖkust: en fotoflora. Uppsala Artdatabanken Publ SLU, Sweden, pp 1-282

Trung VT, Ly BM, Hau LN, Hang NT (2013) Research to produce ethanol from seaweed biomass Cladophora sp. J Mater Sci Eng B 3:670-676

Tuzen M, Sari A (2010) Biosorption of selenium from aqueous solution by green algae (Cladophora hutchinsiae) biomass: equilibrium, thermodynamic and kinetic studies. Chem Eng J 158:200-206

Van den Hoek C (1963) Revision of the European species of Cladophora. EJ Brill, Leiden 
Van den Hoek C (1981) Chlorophyta: morphology and classification. In: Lobban CS, Wynne MJ (eds) The biology of seaweeds. Blackwell Sci Publ, Oxford, pp 86-132

Van den Hoek C (1982) A taxonomic revision of the American species of Cladophora (Chlorophyceae) in the North Atlantic Ocean and their geographic distribution. Royal Netherlands Academy of Arts \& Sciences, Amsterdam, pp 1-236

Van den Hoek C, Chihara M (2000) A taxonomic revision of the marine species of Cladophora (Chlorophyta) along the coasts of Japan and the Russian Far-east. Natl Sci Museum Monogr (Tokyo, Japan) 19: $1-242$

Van den Hoek C, Mann DG, Jahns HM (1995) Algae: an introduction to phycology. Cambridge University Press, Cambridge

Wallentinus I (1979) Environmental influences on benthic microvegetation in the Trosa-Askö area, northern Baltic proper II. The ecology of macroalgae and submersed phanerogams. Contrib Askö Lab Univ Stockholm Sweden 25:1-210

Whitton B (1970) Biology of Cladophora in freshwaters. Water Res 4: 457-476

Wik-Sjöstedt A (1970) Cytogenetic investigations in Cladophora. Hereditas 66:233-262

Wong SL, Clark B, Kirby M, Kosciuw RF (1978) Water temperature fluctuations and seasonal periodicity of Cladophora and Potamogeton in shallow rivers. J Fish Res Board Canada 35:866870

Yarnpakdee S, Benjakul S, Senphan T (2019) Antioxidant activity of the extracts from freshwater macroalgae (Cladophora glomerata) grown in Northern Thailand and its preventive effect against lipid oxidation of refrigerated eastern little tuna slice. Turkish J Fish Aquat Sci 19:209-219

Yoshida T, Suzuki M, Yoshinaga K (2015) Checklist of marine algae of Japan (revised in 2015). Japanese J Phycol 63:129-189

Yoshii Y, Hanyuda T, Wakana I, Miyaji K, Arai S, Ueda K, Inouye I (2004) Carotenoid compositions of Cladophora balls (Aegagropila linnaei) and some members of the Cladophorales (Ulvophyceae,
Chlorophyta): their taxonomic and evolutionary implication. J Phycol 40:1170-1177

Young EB, Tucker RC, Pansch LA (2010) Alkaline phosphatase in freshwater Cladophora-epiphyte assemblages: regulation in response to phosphorus supply and localization. J Phycol 46:93-101

Yuvaraj N, Kanmani P, Satishkumar R, Pattukumar V, Arul V (2011) Extraction, purification and partial characterization of Cladophora glomerata against multidrug resistant human pathogen Acinetobacter baumannii and fish pathogens. World J Fish Mar Sci 3:51-57

Yuvarani M, Kubendran D, Salma Aathika AR, Karthik P, Periyaraman Premkumar M, Karthikeyan V, Sivanesan S (2017) Extraction and characterization of oil from macroalgae Cladophora glomerata. Energy Sources A 39:2133-2139

Zbakh H, Chiheb I, Motilva V, Riadi H (2014) Antibacterial, cytotoxic and antioxidant potentials of Cladophora prolifera (Roth) Kutzing collected from the Mediterranean coast of Morocco. Am J Phytomed Clin Ther 2:1187-1199

Żbikowski R, Szefer P, Latała A (2007) Comparison of green algae Cladophora sp. and Enteromorpha sp. as potential biomonitors of chemical elements in the southern Baltic. Sci Total Environ 387: 320-332

Zhang HM, Geng G, Wang JJ, Xin Y, Zhang Q, Cao DJ, Ma YH (2019) The remediation potential and kinetics of cadmium in the green alga Cladophora rupestris. Environ Sci Pollut Res 26:775-783

Zubia M, Robledo D, Freile-Pelegrin Y (2007) Antioxidant activities in tropical marine macroalgae from the Yucatan Peninsula, Mexico. J Appl Phycol 19:449-458

Zulkifly SB, Graham JM, Young EB, Mayer RJ, Piotrowski MJ, Smith I, Graham LE (2013) The genus Cladophora Kützing (Ulvophyceae) as a globally distributed ecological engineer. J Phycol 49:1-17

Publisher's note Springer Nature remains neutral with regard to jurisdictional claims in published maps and institutional affiliations. 